\title{
THE LEPIDOPTERA OF THE KOOTENAI DISTRICT OF BRITISH COLUMBIA.
}

\author{
By Harrison G. Dyar.
}

Custodian of Lepidoptera.

The Kootenai district of British Columbia occupies the southeastern corner of the province, immediately north of the western part of Montana, Idaho, and the eastern end of Washington. It covers the headwaters of the Columbia River, which here makes a great bend around the Purcell Range to the north, while the Kootenai River, starting at the same point, makes a similar bend to the south into Montana and Idaho and returns to join the Columbia to the west. The country thus inclosed is practically a solid mass of mountains. Several closely parallel ranges, the Rocky Mountains, Purcell Range, and Selkirks, traverse it from north to south, so that from an elevation nothing can be seen in all directions but a mass of mountain peaks. None of these are of great height, but average 6,000 to 10,000 feet. The narrow valleys are filled by long lakes, widenings or branches of the Columbia or Kootenai rivers. The surface of the country is, therefore, steep and rugged and is well forested with coniferous trees. This forest has not been impaired to a perceptible extent by civilization, though large areas are periodically burned over. The resulting waste is gradually covered with a growth of small deciduous trees and bushes. The small town of Kaslo on Kootenai Lake is in the heart of this district, and at that point the principal collections of Lepidoptera have been made. Three months were spent here in collecting during the summer of 1903 . I was assisted by Mr. A. N. Caudell and Mr. R. P. Currie, as well as by the experience of Mr. J. W. Cockle, who has been long a resident in Kaslo and has made a local collection of Lepidoptera at that place for several years. I shall frequently refer to his collection in the following pages. I am especially indebted to Doctor Hartin, of Kaslo, for the loan of his excellent microscope during the summer. 
The Kootenai district contains two faunal regions, conditioned indirectly rather than directly by the altitude. None of the peaks reach timber line, or at least exceed it enough to form a defined alpine zone, as in the Rockies of Colorado. Still the upper slopes of the mountains, on account of their steepness, ruggedness, and exposure to the wind are largely devoid of trees. This effect is heightened by the presence of large areas of snow in favored spots, many of these areas forming permanent fields and glaciers. These cool the neighborhood and produce a more arctic climate not conditioned by the absolute altitude. In such areas grasses and sedges occur with other northerly plants, and a subaretic insect fauna is found to correspond. This region was but little explored by us on account of the difficulty of access, and I have no descriptions of the larvæ of its moths. Breeding work was carried on in Kaslo at an altitude of 1,700 feet. From there to 7,000 or 8,000 feet the fauna is practically uniform, differing in the later appearance of the same species. Toward the upper edge of the coniferous belt, somewhat more northern forms occur, but there is no markedly different region except that of the grassy spots on the peaks. Besides Kaslo, small collections were made at Bear Lake, Sandon, Lardo, Nelson, West Robson, Nakusp, Revelstoke, Glacier, and Field, showing the general uniformity of the faunal character of the district.

The Kootenai district is, for a western locality, comparatively rich in Lepidoptera. The Noctuidæ and Geometridæ form the bulk of the species, and these are, rather unexpectedly, for the most part not inhabitants of the coniferous forest, but feed upon the deciduous plants. Therefore we found Kaslo an exceptionally good collecting ground. The region had been completely burned over some years ago and is now densely grown to deciduous plants. The comparative absence of commercial activity has tended to increase these conditions, for even in the town itself collecting conditions are established in the neglected yards of the many deserted houses, one might almost say in the very streets of the town. The season of 1903 was not a good one, for no apparent reason. Butterflies were unusually scarce, and moths likewise in the early part of the season. Later they reached about their average abundance. With my own collections and those of Mr. Cockle, approximately 25,000 specimens have been under examination, in spite of the poorness of the season.

The fauna of our area, while showing its own peculiarities, seems nearest allied to that of the Sierra Nevadas of California. Presumably a still closer affinity would be found to the Cascade Range of Oregon and Washington, but that region is little known at present. Many of the species either occur in California, or are represented by close allies there. The fauna of the coast region of British Columbia differs perceptibly, in fact, more than I had anticipated would be the case; while on the other side of the Kootenais, the main range of the Rockies, 
while not explored by us, shows markedly different features, as I judge from a brief stop at Banft, Alberta.

It has seemed desirable to publish as complete a list of the species of Lepidoptera occurring in the Kootenai district as can be done at the present time. To this I have added what larval notes I could secure; 167 species of larvæ are noticed out of 653 species of adults.

In the following account of the species taken, the dates of capture are given. If these are followed by no locality in parentheses, Kaslo is to be understood. When a place is mentioned without province or State, it is supposed to be in British Columbia. The following special localities in the Kootenai district are mentioned:

Ainsworth, altitude 2,500 to 5,000 feet. A small place on Kootenai Lake about 12 miles south of Kaslo. The collecting there was done on the hills above the town, mostly comparatively high altitude species being taken.

Banff, Alberta, altitude 4,500 feet. In the main range of the Rockies on the eastern side of the divide and not in the Kootenai district. It is mentioned once or twice for comparison.

Bear Lake Mountain, altitude 7,000 feet. An unnamed mountain to the north of Bear Lake, about 20 miles west of Kaslo. This was one point where high altitude species were obtainable owing to the trail leading to the "London Hill mine," which is situated near the summit of the mountain.

Field, altitude 4,050 feet. In the main range of the Rockies on the western side of the divide but practically within the Kootenai district. High altitude forms were taken here.

Frye Creek, altitude 1,670 feet. A point on Kootenai Lake on the eastern side, about 12 miles north of Kaslo.

Glacier, altitude 4,122 feet. A station on the main line of the Canadian Pacific Railroad in the Selkirks, nearly at the summit of the range and about 100 miles north of Kaslo. A good spot for high altitude species.

Kaslo, altitude 1,670 feet. The immediate environment of the town furnished the bulk of these collections.

Kokance Mountain, altitude 10,000 feet. A mountain in the Selkirks, southwest of Kaslo, and almost in sight from that place. The summit is covered with a large snow field and glaciers. A few high altitude forms were taken here on the grassy slopes near the summit.

Lardo, altitude 1,670 feet. A point at the north end of Kootenai Lake.

Nakusp, altitude 1,350 feet. On Arrow Lake, a widening of the Columbia River, before it is joined by the Kootenai River and almost due west of Kaslo.

Nelson, altitude 1,670 feet. At the outlet of Kootenai Lake, southwest of Kaslo, with essentially the same faunistic conditions. 
Payne Wine, altitude 3,600 feet. In the Selkirks west of Kaslo, a little west of the summit of the range.

Revelstoke, altitude 1,475 feet. A station on the main line of the Canadian Pacific railroad on the Columbia River nearly due west of Glacier.

Sandon, altitude 3,600 feet. Within a few miles of Payne Mine in the same region.

South Fork Creek, altitude indefinite, over 2,500 feet. Specimens with this label were taken on the trail between Kaslo and Kokanee Mountain, mostly from horseback and at the higher altitudes of the trail. It follows the course of the South Fork of Kaslo Creek to its source in the glacier.

West Robson, altitude 1,315 feet. At the Junction of the Columbia and Kootenai Rivers.

\section{Family PARNASSIIDA.}

PARNASSIUS SMINTHEUS Doubleday and Hewitson.

Two specimens, July 28 (Bear Lake Mountain), 29 (Bear Lake Mountain).

Family PAPILIONIDA.

PAPILIO EURYMEDON Boisduval.

Five specimens, May 31, June 1, 15. About equally common with rutulus and occurring with it. Eggs and larvæ were found later on Ceanothus.

PAPILIO RUTULUS Boisduval.

One specimen, May 29. The species was not uncommon in spring, coming to flowers in the garden. The larva were found later feeding: on birch and other plants.

PAPILIO GLAUCUS Linnæus.

No specimens; Mr. Cockle has one from the Kootenai District which he thinks referable to this specses.

PAPILIO ZOLICAON Boisduval.

No specimens; Mr. Cockle has it in his collection.

$$
\text { Family PIERID A. }
$$

NEOPHASIA MENAPIA Felder.

No specimens. The butterfly had not yet begun to fly at the time I left Kaslo. I found them commonly in September on Vancouver Island. Mr. Cockle has taken the species. 
PONTIA BECKERI Edwards.

No specimens; Mr. Cockle has taken it.

PONTIA OCCIDENTALIS Reakirt.

Two specimens, July 21 (Bear Lake Mountain).

PONTIA OCCIDENTALIS, var. CALYCE Edwards.

Fíve specimens, July 29 (Bear Lake Mountain).

PONTIA NAPI Linnæus, var. VENOSA Scudder.

Two specimens, May 29, June 3.

PONTIA NAPI Linnæus, var. PALLIDA Scudder.

One specimen, July 23 (Frye Creek).

PONTIA RAPÆ Linnæus.

Six specimens, May 30, July 7, 8, 19. Many more could have been taken as the species was common in the streets of the town.

SYNCHLOE SARA Boisduval.

Nine specimens, May 29, 30, 31, June 4, 5, 7.

EURYMUS EURYTHEME Boisduval, var. ERIPHYLE Edwards.

One specimen, July 19.

EURYMUS INTERIOR Scudder.

Five specimens, June 15, 26, July 2.

Family NYMPHALID Æ.

ARGYNNIS RHODOPE Edwards.

Thirteen specimens, July 10 (Ainsworth), 11 (Ainsworth), 21 (Bear Lake Mountain), 26 (Payne Mine), 29 (Bear Lake Mountain). Some of the specimens are a little smaller and darker on the upper side than Edwards's figure of specimens from the Frazer River, but others fit it very closely. The species was named monticola in Mr. Cockle's collection, but not correctly, I think.

\section{ARGYNNIS BEHRENSII Edwards.}

One specimen, July 10 (Ainsworth). It is a male, with only a trace of silver on the hind wings below. What there is of it is most distinct on the submarginal lunules. 
ARGYNNIS ELECTA Edwards.

Four specimens, July 10 (Ainsworth), 11 (Ainsworth), 21 (Bear Lake Mountain).

ARGYNNIS EURYNOME Edwards.

Two specimens, July 21 (Bear Lake Mountain), 29 (Bear Lake Mountain).

ARGYNNIS EURYNOME, var. CLIO Edwards.

Two specimens, July 21 (Bear Lake Mountain), 29 Bear Lake Mountain).

BRENTHIS EPITHORE Boisduval.

Thirteen specimens, May 31, June 8, July 11 (Ainsworth), 21 (Bear Lake Mountain).

LEMONIAS ANICIA Doubleday and Hewitson, var. BEANI Skinner.

Seven specimens, July 16, 21 (Bear Lake Mountain), 29 (Bear Lake Mountain).

\section{LEMONIAS PALLA Boisduval.}

Three specimens, June 25, 26, July 2.

PHYCIODES THAROS Drury.

Seven specimens, June 15, 26, July 2, 21 (Bear Lake Mountain), 23 (Frye Creek), August 9 (South Fork Creek).

\section{PHYCIODES PRATENSIS Behr.}

Four specimens, July 11 (Ainsworth), 19, 21 (Bear Lake Mountain), 26 (Payne Mine).

POLYGONIA SATYRUS Edwards.

Six specimens, June 11, 25, July 8 (bred), 15. The early specimens were hibernated, the later ones bred from larvæ on nettle. Both the light form satyrus and the dark one marsyas emerged in about equal proportions from the pupæ. The larva is white all over the dorsal region and looks like the eastern comma Harris.

POLYGONIA FAUNUS Edwards.

Two specimens, June 6,18 , both hibernated. No larvæ were seen, but no search of the willows was made for them. 


\section{POLYGONIA ZEPHYRUS Edwards.}

Twelve specimens, May 30, June 8 (Ainsworth), 15, July 7 (bred), 16 (bred), and others seen. The early specimens were hibernated, the later ones bred from larvæ. The larvæ occurred on both currant and Rhododendron, but there was no difference between them, though the variation in color is considerable.

\section{EUGONIA J-ALBUM Boisduval and Le Conte.}

No specimens; Mr. Cockle has taken it.

EUGONIA CALIFORNICA Boisduval.

Eleven specimens, July 16, 19, 21 (Bear Lake Mountain), Augusc 9 (South Fork Creek), 11. Many others could have been taken, as the butterflies came in the daytime in some numbers to the sugar left on the stumps to attract moths at night. The species was, however, unusually rare, only a very few larvæ being seen on the Ceanothus bushes, where they are generally plentiful, according to Mr. Cockle's observations.

\section{EUVANESSA ANTIOPA Linnæus.}

Six specimens, bred August 2, from larvæ fed by Mr. Cockle. The species occurred occasionally all summer, but was not abundant.

AGLAIS MILBERTI Godart, var. SUBPALLIDA Cockerell.

Two specimens, June 2, July 29 (Bear Lake Mountain). Seen occasionally all summer, the larvæ and egg masses on nettle.

\section{VANESSA ATALANTA Linnæus.}

No specimens; Mr. Cockle has taken it.

VANESSA HUNTERA Fabricius.

No specimens; Mr. Cockle has found the species very rare at Kaslo.

VANESSA CARDUI Linnæus.

One specimen, July 29 (Bear Lake Mountain). The species was common all the season but no effort was made to capture any. The larvæ were frequent on thistles and several other plants.

\section{VANESSA CARYE Hübner.}

No specimens taken. The species was less common than cardui, yet not infrequent. The larvæ occurred on cultivated hollyhock, to which they were rather injurious. 
BASILARCHIA LORQUINII Boisduval.

Six specimens June 14, 26, July 15, 21 (Bear Lake Mountain), 26 (Payne Mine). Many others seen but not pursued. The amount of orange color at the tip of the wing is somewhat reduced as compared with Californian examples. Mr. Cockle found a larva on willow.

Family AGAPETID A.

CERCYONIS SYLVESTRIS Edwards, var. CHARON Edwards.

Six specimens, June 26, July 10 (Ainsworth), August 7.

Family LYMNADID A.

ANOSIA PLEXIPPUS Linnæus.

No specimens; Mr. Cockle has this butterfly from Kaslo.

Family LYCANID E.

URANOTES MELINUS Hübner.

No specimens; but Mr. Cockle has some in his collection.

THECLA CALIFORNICA Edwards.

Four specimens, July 2, 15, August 9 (South Fork Creek).

THECLA S ÆPIUM Boisduval.

Eight specimens, July 15, 18, 19.

THECLA NELSONII Boisduval.

Nine specimens, May 29, 31, June 7, 10.

THECLA SPINETORUM Boisduval.

Two specimens, June 1, 4; one of them left in Mr. Cockle's collection, as this is a new record for Kaslo.

INCISALIA IROIDES Boisduval.

Six specimens, May 29, June 1, 6, 8 (Ainsworth), 9, 11. Mr. Cockle has specimens in his collection labeled irus and augustus, but I doubt whether they represent species different from iroides. The three species are closely allied, but irus and augustus are not known from the west.

INCISCALIA ERYPHON Boisduval.

Eight specimens, May 31, June 8 (Ainsworth). 
EPIDEMIA MARIPOSA Reakirt.

Thirteen specimens, June 25, 26, 29, July 2, 21 (Bear Lake Moun tain), 23 (Frye Creek), 29 (Bear Lake Mountain).

EPIDEMIA HELLOIDES Boisduval.

Nine specimens, July 15, 21 (Bear Lake Mountain), 26 (Payne Mine), 28 (Bear Lake Mountain).

EPIDEMIA DORCAS Kirby, var. FLORUS Edwards.

No specimens; Mr. Cockle has some in his collection so labeled.

CHALCERIA SNOWI Edwards.

One specimen, July 21 (Bear Lake Mountain).

CUPIDO SAEPIOLUS Boisduval.

Eight specimens, June 1, 6, 11, 27.

NOMIADES LYGDAMUS Doubleday.

One specimen, July 21 (Bear Lake Mountain).

AGRIADES PODARCE Felder.

Four specimens, July 21 (Bear Lake Mountain). An alpine form of podarce, the under side of hind wings very dark gray with the white spots contrasted. The female is peculiarly marked with spots of bluish scales on the upper side.

RUSTICUS ANNA Edwards.

Six specimens, July 21 (Bear Lake Mountain), 26 (Payne Mine).

CYANIRIS LADON Cramer, var. NIGRESCENS Fletcher.

Fifteen specimens, April 25 (Mr. Cockle), May 1 (Mr. Cockle), 10 (Mr. Cockle), 29, 31, June 1, 5, 6.

\section{EVERES COMYNTAS Godart.}

Three specimens, June 4, 8 (Ainsworth), 14. Mr. Cockle has this labelled amyntula, but they are more like my eastern comyntas than the Californian amyntula.

Mr. Cockle has in his collection specimens identified as acmon, battoides, melissa, daedalus, fulla, antiacis, and cooperi; but they are not before me and were not taken by us. 
Family HESPERIIDA.

AMBLYSCIRTES VIALIS Edwards.

Six specimens, May 31, June 2, 4, 7, 16.

ERYNNIS COMMA Linnæus, var. MANITOBA Scudder.

No specimens; Mr Cockle has it.

ANTHOMASTER AGRICOLA Boisduval.

Fourteen specimens, July 7, 11, 12, 23 (Frye Creek), August 3, 5. PAMPHILA PALÆMON Pallas.

No specimens; Mr. Cockle has taken it.

THORYBES PYLADES Scudder.

No specimens; it is in Mr. Cockle's collection.

THANAOS ICELUS Lintner.

Four specimens, May 29, June 6, 8, 10.

THANAOS LILIUS, new species.

Two specimens, May 31, June 4. This form resembles tucitius Lintner, but is larger, the wing more variegated with brown, which shows distinctly in a patch at the end of the cell, cut by an erect dark line on the cross vein. Otherwise it is very similar. The size is that of martialis, but the markings are diffused and not as contrasted as in that species. It is the western representative of lucilius, probably a geographical race of it, but as much entitled to specific rank as several other species of the genus. I have specimens from Easton, Washington (Koebelè), and Yosemite Valley, California, June 16 and August 5 (Dyar).

Type. Cat. No. 7333, U. S. National Museum.

HESPERIA MONTIVAGA Reakirt.

No specimens; a few were seen, but escaped capture. Mr. Cockle has the species.

HESPERIA CASPITALIS Boisduval.

Six specimens, May 29, June 2, 6 .

\section{Family SPHINGIDA.}

HEMARIS DIFFINIS Boisduval, var. THETIS Grote and Robinson.

Three specimens, May 30, 31, June 15, at flowers of lilac. Others were seen, but not captured. The form has distinct red tips on the 
fore wings (mbens Hy. Edwards). The species extends throughout temperate North America. Larvæ from the Atlantic region have been described by Grote, Coquillett, Fischer, Holland, and Smythe, feeding on snowberry. Mr. Cockle found an egg on this plant at Kaslo, and Mr. Caudell obtained a young larva.

Egg.-Elliptical, symmetrical, narrowed in dorsoventral diameter; leaf green, minutely shagreened over a fine, obscure, hexagonal reticulation, scarcely shining. Size, 1.3 by 1.15 by $1 \mathrm{~mm}$.

Stage I.-Head rounded, cap-like, slightly bilobed, black on the face, but diluted on the sides almost to luteous; epistoma pale; eyes black. Body normal, horn rather long, stout, tapered, black, bearing two setæe at the tip. Color pale yellow, cervical shield large, black. Setæ furcate, T-shaped, distinct, black; i dorsad to ii, $\mathrm{v}$ dorsad to iv on subventral fold; no subprimaries; on the thorax ia and ib, iia and iib from single tubercles; vi of two small separate setæ; vii and viii small, black on the legless segments. Horn minutely capitately setose. Later the color is whitish, the segments finely annulate, a faint pale subdorsal line from joint 2 to the horn.

Stage II.-Head rounded, high, the apex under joint 2, smoky green, shaded with blackish over the face below, pilose with fine secondary hairs; width $1 \mathrm{~mm}$. Body normal, the horn moderate, conical, tapered; black, setose. Segments finely annulate and with numerous secondary granules, tubercle i showing as a larger granule; a row of large ones on the collar. Green, shaded with smoky blackish except at the ends, a pale subdorsal line from joint 2 to the horn. Venter and feet nearly black.

Stage III.-Head rounded, higher than wide, somewhat conoidal; green with a vinous brown shade about the eyes extending upward in a diffuse band each side of the clypeus nearly to vertex; secondary granules whitish; width, $1.8 \mathrm{~mm}$. Body green, annulate, with dense secondary white granules. Horn long, tapered, black except at the sides at base where it is luteous; subventral region to spiracles shaded in vinous brown, tinting the feet except the plates of the anal pair. A narrow white subdorsal line; spiracles faintly ocherous.

Stage IV.--Head as before, the dark shade faint and detached from the ocellar patch; width, $2.3 \mathrm{~mm}$. Green, the dorsum whitish, sides yellowish; granules white or yellow; dorsal shade bluish green; subdorsal line pale yellow, white at the horn, which is black at tip, reddish and luteous at base. Spiracles orange, more or less surrounded by oblique brown spots. Venter purple brown, feet dark luteous, anal flap and footplates green.

Stage V.-Head green with white granules, epistoma white, antennæ brown; width, $3.3 \mathrm{~mm}$. Body as in the previous stage. 


\section{LEPISESIA FLAVOFASCIATA Walker.}

Six specimens, June $6,7,9$, at flowers of lilac. Mr. Cockle has several others. The specimens vary in the width of the orange band on the hind wings from a broad band to near obsolescence. The collar may be deep black or only slightly blackish, as indicated by the varietal names ulalume Strecker and rachel Bruce. Mr. Bruce has noted the larva on Epilobium. ${ }^{a}$ Eggs were obtained from captive females and the little larvæ selected this plant from a variety of plants offered them. Until the last stage the larva is green with a red anal horn; in the last stage nearly coal black with a shining button. The change is remarkable and interesting.

Egg.-Regularly elliptical, roundedly flattened above and below; smooth, shining pale green, finely shagreened. Fine reticulations are obsoletely indicated under 87 diameters. Size, 1.3 by 1.1 by $1 \mathrm{~mm}$.

Stage I.-Head rounded, slightly bilobed, full, pale greenish; width, $0.6 \mathrm{~mm}$. Body cylindrical, equal, anal feet with triangular plates, horn moderate, stout. All pale greenish without any marks, the terminal setæ of the horn only blackish. Segments finely annulate; not shining, opaque. Tubercles and setæe rudimentary, a minute brown button with a short bulbous seta, consisting of a sphere on a short pedicle; i dorsad to ii, $\mathrm{v}$ well dorsad to iv, vi not present, a long, normal seta on the leg base; on thorax ia and ib, iia and iib approximate, vi of two remote bulbs. Setæ on the head bulb-shaped except those at the mouth. No shields.

Stage II.-Head rounded, full, whitish green, ocelli black; width $1.1 \mathrm{~mm}$. Body green, the segments finely 8-annulate, with secondary granular dots whitish; horn moderate, tapered, shining green, the outer part purple; joint 2 dorsally shining; an obscure white subdorsal line, not touching the horn. Anal footplates large, green.

Stage III.-Head rounded, bilobed, apex in joint 2, whitish green, opaque, not shining; width $1.8 \mathrm{~mm}$. Body normal, feet small, segments 8-annulate, horn moderate, tapered. Whitish green, subpruniose, with obscure secondary white dots; subdorsal line white, rather broad, from joint 2 posteriorly to joint 13 anteriorly, bent up toward but not touching the horn. Horn black, greenish at sides at base, a little purple tinted. Feet green; spiracles whitish.

Stage IV.-Green, scarcely whitish except for the white dots; subdorsal line more contrasted. Horn with outer third black, middle light red, base greenish white with a black dorsal line and obscure black.ring around the base. Spiracles yellowish white with fine black edge. Width of head, $2.6 \mathrm{~mm}$.

Stage V.-Head rounded, about as high as wide, sutures scarcely depressed, sooty black; epistoma, labrum, and antennæ greenish white; 
width, $3.7 \mathrm{~mm}$. Body normal, horn replaced by an elliptical button, $2.5 \mathrm{~mm}$. long, the speculum black, shining, wrinkled and raised to a boss behind, surrounded by a narrow yellow ring and a broad, velvety black one. Body cylindrical, feet moderate, anal plates large. Olivaceous black, dotted with sooty black secondary granules; leg-plates black, thoracic feet greenish white; spiracles contrasted, bright ferruginous ochraceous; claspers of abdominal feet greenish. Slight dorsal and subdorsal velvety-black checkerings; all lines absent.

The larva entered earth to pupate.

DEILEPHILA GALLII Rottemburg.

Two specimens, June 5, August 13 (Sandon; Mr. Currie). No effort was made to take this cosmopolitan species in series. A larva on Epilobium was prepared by Mr. Caudell.

SPHINX VANCOUVERENSIS Hy. Edwards.

No specimens. It did not occur to us either as larva or adult, though Mr. Cockle has taken it in former years. I have described the larva on snowberry. ${ }^{a}$

\section{MARUMBA MODESTA Harris.}

No specimens; Mr. Cockle has recorded it.

\section{SMERINTHUS CERYSII Kirby.}

Five specimens, June 1 (bred by Mr. Cockle), 24, 25, July 22. All the specimens are gray, like southern Californian ones, yet varying in markings; some seem nearest astarte Strecker, others more like ophthalmicus Boisduval. They connect these forms. Larvæ were obtained from eggs. Descriptions are already extant by Boisduval, Hy. Edwards, French, and myself.

PAONIAS EXCÆCATUS Smith and Abbot.

No specimens; it is in Mr. Cockle's collection.

PAONIAS MYOPS Smith and Abbot.

No specimens; Mr. Cockle has it.

\section{Family SATURNIID \&.}

\section{SAMIA RUBRA Behr.}

One specimen, June 11. The form is nearest to Californian mbra, but a little divergent, approaching gloveri in some respects. The tone of the wings is grayer, especially toward the margin, and the discal 
spots are less produced. Mr. Cockle is acquainted with the larva on Ceanothus, but none occurred to us. The Ceanothus bushes were badly defoliated as the result of the work of Tineids (Lyonetia speculella Clemens), which evidently deprived other species of their accustomed food and perhaps drove away the moths which would have deposited eggs.

TELEA POLYPHEMUS Cramer.

One specimen, June 29. Mr. Cockle has a good series in his collection. This species tends toward a local race in the Kootenay district. The moths are distinctly more pink and gray than any others that I have, while the peculiar manner of spinning the cocoon with an attachment to the twig, which has been noted by Grote as occasional, ${ }^{a}$ seems here the usual method, according to Mr. Cockle. ${ }^{b}$ Eggs and larvæ were found by Mr. Caudell, and other eggs obtained from female moths by Mr. Cockle.

\section{PSEUDOHAZIS SHASTAENSIS Behrens.}

Three specimens, two bred by Mr. Cockle from hibernating pupæ June 27, and a pair taken with the net by Mr. Caudell in July, the male of which was destroyed in eapturing it. I found a brood of young larvæ June 11 on willow. They grew slowly and were not full fed in August when we lost them. It seems probable from these data that the species takes two years to reach maturity, hibernating first in the egg and second in the pupa.

\section{Family SYNTOMID Æ.}

SCEPSIS PACKARDII Grote, var. COCKLEI, new variety.

Six specimens, June 25, 27, July 2. Mr. Cockle has others in his collection. The species exhibits a distinct local form or race. They have the size and appearance of packardii, but nearly the coloration of fulvicollis Hübner, the fore wings being largely blackish and somewhat translucent centrally, with only a little of the light-brown tint that occupies the whole wing in packardii. Expanse, $42 \mathrm{~mm}$. I take pleasure in dedicating this form to $\mathrm{Mr}$. Cockle. We endeavored to obtain the life history, but could not find more than one female moth, and that was unfortunately killed before it came into our hands.

Type.-Cat. No. 6989, U. S. National Museum.

\section{Family LITHOSIID AE.}

\section{CRAMBIDIA CASTA Sanborn.}

One specimen, August 22 (Revelstoke), of the normal large form with white head.

$b$ Can. Ent., XXXV, 1903, p. 139. 


\section{LEXIS BICOLOR Grote.}

One specimen, August 13, normal.

HYPOPREPIA MINIATA Kirby.

Twenty-three specimens, July 4, 13, 14, 23, 31; August 1, 3, 5, at light or on leaves in the daytime. Only the species miniata occurred. The absence of fucos $a$ confirms the distinctness of these forms, which were formerly regarded as varieties of one species. The larva lives on lichens on bark of trees or stones. Eggs were readily deposited by captive females. The larva hibernates when about half grown.

Egg.-Shape of two-thirds of a sphere, with flat base, scarcely conoidal. Reticular areas flattened, their joinings not raised, yet very distinct, regularly hexagonal, making the surface polyhedral. Shining dark lead color; diameter, $0.8 \mathrm{~mm}$. Laid perfectly loose, rolling about in the dish.

Stage I.-Head round, bilobed, full, brown black; the mouth pale. Body normal, Aretiiform. Tubercles conic, high; all light orange brown. The alimentary canal darker anteriorly; tubercles concolorous; setæ coarse, stiff, spinulose. Tubercle i small, pale; ii very large, thick, black; the others pale, but rather stout, single; on the thorax ia and ib contiguous, iia also approximate to them, iib separate. Shield concolorous.

Stage II.-Head bilobed, black; mouth brown; width, $0.5 \mathrm{~mm}$. Body robust, light brown, with fine dark granules, immaculate. Warts small, colorless; the setæ remarkably large and coarse. Feet pale; no shields. Tubercles i and ii single haired, iii with two hairs, iv to vi single and weak; hairs of i to iii are coarse, black, and barbuled. On thorax ia $+\mathrm{ib}+\mathrm{iia}$, iib small, iii and iv approximate, $\mathrm{v}$ not very remote. Later the larva becomes dull brown, with a pale, waved subdorsal line.

Stage III.-Head black; width, $0.65 \mathrm{~mm}$. Body brown, with a light yellowish subdorsal band, incising the dorsal area intersegmentally on its upper side. Hairs black; structure as before.

The life history was not completed.

CLEMENSIA ALBATA Packard.

Eight specimens, July 4, 15, 29, 31; August 4, 5, 6. The larvæ were obtained from eggs laid by a captive female, but the life history was not completed, as the larvæ hibernated. They fed on lichens.

Egg.-Spherical, the base scarcely flattened, smooth, neatly reticulate, the reticulations a little elongate vertically; pale yellow, surrounded by long fine hairs from the moth, which stand nearly erect; diameter, $0.8 \mathrm{~mm}$. The egg is very large for the size of the moth.

Stage I.-Head round, bilobed, shining luteous, dotted with black over the vertex, but leaving an elliptical pale patch on the summit of

Proc. N. M. vol. xxvii-03-55 
each lobe; eye black, mouth brown. Body moderate, a little more slender centrally, colorless transparent; no shields. Tubercles small, elevated on rounded wart areas, single, separate, no subprimaries, iv substigmatal posteriorly, ia and ib of the thorax separate, but more approximate than iia and iib. Setæ pointed, stiff. Feet normal, with long slender claspers. Male glands plainly visible in joint 9, sordid brown. Later the larva is slightly brown speckled; joints 4, 7, and 11 subdorsally, with distinct diffuse brown spots.

Stage II. - Head whitish below, brown black over the vertex, mouth large; width, $0.55 \mathrm{~mm}$. Bodv short and robust, Arctiiform; tubercles i and ii single, separate, i dorsad, iii with two hairs rather remote, iv and $v$ single, iv stigmatal posterior, $v$ subventral, vi with two hairs, a short hair on the colorless leg plate. Colorless, whitish, broadly reticulate in brown, on joints 4,7 , and 11 segregated into a distinct subdorsal patch, illy defining a dorsal and subdorsal line of ground color. No distinct lines. No true warts, the base of the hair conically enlarged, concolorous. Hairs pale, weak.

The larvæ were not carried further.

Family ARCTIID A.

\section{LEPTARCTIA CALIFORNIÆ Walker.}

Two larvæ, bred by Mr. Cockle from eggs that he had obtained. The species was not common. No effort was made to take specimens, as they showed no unusual characters. The larva is rather characteristic by the long bush of hairs arising on the posterior segments. This was especially conspicuous in some larvæ collected by $\mathrm{Mr}$. A. W. Hanham at Victoria, but was not at all noticeable in specimens from Golden, Colorado. The Kaslo larvæ are intermediate, but nearer the coast form.

\section{ESTIGMENE ACR EA Drury.}

No specimens; it is in Mr. Cockle's collection.

ISIA ISABELLA Smith and Abbot.

No specimens; Mr. Cockle has taken it.

DIACRISIA VIRGINICA Fabricius.

Fourteen specimens, May 29, June 1, 3, 4, 7, 11, July 4. More could have easily been obtained, but they did not differ in any respect from the species as it occurs throughout North America.

\section{DIACRISIA KASLOA Dyar.}

Thirty-four specimens, May (Mr. Cockle), May 30, June 3, 4, 5, 12, 16, August 13 (Sandon, Mr. Currie). Nearly allied to the Californian vagans, but distinguished by the bright red color of both sexes. Some 
of the males are of a duller brown, approaching a rare Californian variety, and some specimens from Rossland (vagans) have a brownish tint. Somewhere between Rossland and Kaslo will be found a dividing line between these species, or they will be seen to intergrade. Larva were obtained from captive female moths.

Egg.-Laid in a mass with a smaller second layer on top. Low conoidal, rather rounded. Reticulations fine, linear, irregularly hexagonal, small; slight markings occasionally within the cell areas like water drops, surface not entirely smooth, slightly coarsely shagreened. Color, waxy white. Size, diameter, $0.9 \mathrm{~mm}$; height, $0.8 \mathrm{~mm}$.

Stage 1.-Head broad, rounded, mouth projecting, pale reddish luteous, eye black, mouth brown. Body normal, Aretiiform, whitish, the cervical shield 5-haired, pale; tubercles large blackish, setæ long, pale. Tubercle iii 2-haired, the rest single on large elongate plates. On thorax ia + ib, iib small separate, vi 2 -haired.

Stage 11.-Head testaceous, shining, smoky on the vertex, eye black, mouth brown; width, $0.5 \mathrm{~mm}$. Body whitish, the food showing green. Tubercle i small, iv as large as any, vi small; warts black with soft long black hairs and some shorter pale ones. Cervical shield small, leg plates dusky.

Stage III.-Head round, bilobed, full, translucent orange; width, $1 \mathrm{~mm}$. Body greenish, sparsely brown dotted, heaviest subdorsally, leaving a faint, pale, dorsal line. Warts black; hair black and white, rather long, sparse.

Stage IV.-Head orange luteous, ocelli black; width, $1.4 \mathrm{~mm}$. Body olivaceous gray, dotted with black. Warts black dorsally, greenish laterally. Hair black and white, irregular, straight. Dorsal pale line defined only by the black dottings. Feet dark.

Stage V.-Head round, bilobed, orange, dotted obscurely with brown; width, $2.1 \mathrm{~mm}$. Body gray, thickly dotted with black, without marks. Warts sordid luteous, partly black or ringed with black, large, normal. Hair stiff, uneven, pointed black and foxy red mixed with a few longer pale ones. Spiracles white.

Stage VI. - Head slightly bilobed, black in front, broadly red over the lobes behind, shining; paraclypeus, epistoma, labrum and antennæ sordid white, pinkish tinged; width, $3 \mathrm{~mm}$. Body dull brown black, strigose with a paler tint. Feet pale reddish. Warts large, blackish luteous, the hair foxy red, slightly darker tipped, except some longer ones which are most noticenble posteriorly; these are black. Aspect of $D$. virginica, but darker and redder. Spiracles white, black rimmed. A red patch before tubercle iii on joint 12. There is a difference in the color of the dorsal hairs, which may be due to the sex of the larva, as Stretch states to be the case in D. vagans.

Cocoons spun in the ground. 
HYPHORAIA PARTHENOS Harris.

No specimens. One larva found by Mr. Caudell. The species is rare, but Mr. Cockle has several in his collection and has bred one or more. The larva is large, black, with long soft black hairs and whitish warts.

\section{PLATYPREPIA VIRGINALIS Boisduval.}

No specimens; Mr. Cockle has taken it.

APANTESIS ORNATA Packard, var. ACHAIA Grote and Robinson.

One specimen, June 13, at light. Mr. Cockle has others. This form is the same as found in California and the Pacific coast. A description of the larva has been published. ${ }^{a}$

\section{AMMALO TENERA Hübner.}

Three specimens, June 5, 6, 23. They agree with Atlantic coast specimens rather than with the Californian form sciurus, though there is very little difference between these forms at best. Eggs were obtained, but proved infertile.

HALISIDOTA MACULATA Harris, var. ALNI Hy. Edwards.

Thirteen specimens, May 30, 31, June 6, 10, 16, 25. The moths are like typical maculata of the Atlantic coast region, and also like the variety alni, these forms not differing in the adult. The larva are alni, like those of the mountains of California and Colorado, red dorsal tufts when young, no dorsal tufts in the last stage. Some of the larvæ, however, had black dorsal tufts in the last stage, thus resembling the form angulifera Walker of the Pacific coast, but none had black tufts in the early stages as that form has. There was much variation in color, some of the young larvæ being highly variegated with red and yellow.

\section{Family AGARISTID A.}

\section{ANDROLOMA MAC-CULLOCHII Kirby.}

Two specimens, July 21 (Bear Lake Mountain). The larvæ have been described by me. ${ }^{b}$

\section{ALYPIA LANGTONI1 Couper.}

Three specimens, July 13, August 13 (Sandon; Mr. Currie). Others were seen, but the species was rare. Eggs were obtained, but proved infertile. The larva has been described by me. ${ }^{c}$ 


\section{Family NOCTUID A.}

APATELA DACTYLINA Grote, var. HESPERIDA Smith.

Eleven specimens, June 13, 16, 23, 25, 30, July 2. The specimens are generally darker and more smoothly colored than eastern dactylina, but Professor Smith's type of hesperida is not so, and I scarcely see why he should have separated it. Still, hesperida is a good racial form, representing dactylina in the northwest. The larva is essentially the same, though the hairs are of a decidedly brighter brown, and are less markedly keeled on the dorsal line.

Egg.-Flat, circular, low domed; ribs about 80 at the margin, smoothly waved, diminishing by alternation toward apex, which is irregularly lumpy; no reticulations. Dark green, later with little red dots, sparsely scattered. Diameter, $1.4 \mathrm{~mm}$; height, $0.4 \mathrm{~mm}$. Hatched in eight days.

Stage I.-Head bilobed, cordate, white, checkered with a more sordid shade, ocelli and coarse setæ black, jaws brown. Hairs single, the dorsal ones black, long, the lateral ones white and shorter; no subprimaries. Body cylindrical, all white, tubercles large and concolorous; hair of joint 11 all pale; shields undifferentiated.

Stage II.-Head bilobed, a little higher than wide, white with black marks; triangular mark in clypeus, median suture at apex, curved band each side of clypeus and a mark on side; width, $0.8 \mathrm{~mm}$. Body normal with large round warts, white, with white hairs, joints 5, 7, and 12 dorsally with a small dusky patch and a few dark hairs. Hairs soft, long and short mixed.

Stage III.-Head sharply bilobed, with stiff white setæ; shining black, a dash from vertex of lobe, clypeus and epistoma white; width, $1 \mathrm{~mm}$. Body uniform, warts round, projecting, all covered by fine long fluffy white hairs; a long dorsal black pencil on joints 5, 7, and 12; sides broadly powdered with black, inclosing wart iii. Thoracic feet black, abdominal ones pale. Later an ocherous shade appears in the broad white dorsal space.

Stage IV.-Head high, oval, bilobed, clypeal sutures depressed, shining black; width, $1.8 \mathrm{~mm}$. Body black, obscured by the dense secondary hairs, warts ii and iii showing white. Dorsal hairs dense in banded segmentary tuftings, creamy brown; subdorsal and lateral hair long, white, sparse, showing the black ground; erect black peneils on joints 5, 7, and 12 . Feet black, except the claspers of the abdominal ones.

Stage V. Head shining black; width, $3 \mathrm{~mm}$. Body black, the warts obscured, except subventrally by broad bands of dense, secondary hair, light brownish red dorsally, white laterally, mixed with longer white hairs from the lateral warts; joints 5,7 , and 12 with high black 
dorsal pencil; white hairs overhand the extremities. Warts white, moderate.

Stage VI.-Head rounded, oval, high, shining black with primary white setæ; width, $5 \mathrm{~mm}$. Body cylindrical, equal; segments densely banded with secondary hair, slightly keeled along the dorsal line and with large, high, erect pencils of black hair on joints 5, 7, and 9 . Dorsal hair orange brown, side hair creamy white with a few long: pale ones. Skin black, spiracles white, warts obsolete.

Cocoon of silk.

APATELA FELINA Grote.

Three specimens, June 13, 16, 25. Mr. Cockle has had this species in his collection as canadensis Smith and Dyar, but it does not agree with our type, which was from Calgary, Alberta. It is, however, like specimens before me named felina, by Prof. John B. Smith. The Kaslo specimens agree in color with one labeled "Wash. T.;" Californian specimens are lighter. This error in identification illustrates the resemblance of the Kootenai fauna to that of distant California, whence felina was described, rather than to that of the near eastern foothills of the Rocky Mountains toward Calgary.

Egg.-Low, flattened, with a flat, broad, clear base, center domed, yellow; about 20 large, coarse, smooth ribs, irregularly joined by crossbars equally large and smooth, forming a series of large, rounded pits; surface finely sparsely granular shagreened, which alone appears at the micropyle where the ribbing is absent. Diameter to margin, 2 $\mathrm{mm}$; central dome, $1.3 \mathrm{~mm}$; height, $0.6 \mathrm{~mm}$. Later there appears an irregular dark red ring at the edge of the central dome. Hatched in eight days.

Stage I.-Head cordate, black, pale diluted in a little spot each side of the median suture and at vertex (tubercle i), epistoma and antennæ white, not conspicuous. Body white; joints 2, 4-5, 7-9, and 12-13 anteriorly vinous red dorsally. Thoracic feet black. Warts conical, single haired, no subprimaries, i to iii with large black setæ, the rest with smaller ones; iii to $\mathrm{v}$ closely grouped around the spiracle; on thorax ia + ib, iib very small. Skin with minute, rather sparse, conical granules. Leg shields blackish; cervical shield brown-black with three large and one small setæ and two detached. 'Tubercles conical, large but pale.

Stage II.-Head sharply bilobed, shining vinous black, epistoma pale sordid; width $0.8 \mathrm{~mm}$. Body with joints $3,6,10$, posteriorly, 11 pale, white, the rest of the dorsum deep blackish vinous, all the warts dark except ii of 11, which is white. Intersegmentary areas paler. Hairs numerous, long, all black dorsaliy, some white subventrally, long, curling; feet black.

Stage III.- - Head bilobed, median suture sharply depressed; shining black, the coarse setæ white; width, $3.5 \mathrm{~mm}$. Body normal, joint 12 
slightly enlarged. Mostly purple black, dorsal line narrow, white; joint 3 on the sides, 6,10 posteriorly, 11 largely yellowish white; wart ii of joint 3 , ii of 6 and 10 partly and ii of 11 white, all the other warts black; some white along the sides. Dorsal hair long, black, erect, mixed with white on the pale segments and on joints 2 and 13 ; sides with long, fluffy, white hairs, which also overhang the ends. Feet black.

Stage IV.-Head sharply bilobed, shining black, clypeus brownish, epistoma white; width, $2.1 \mathrm{~mm}$. Body held in J shape, a little compressed, warts distinct, rounded and also much secondary hair present. Dorsal black hair-tufts present on joints $5,7,8,9$, and 12 , those of 8 and 9 small; other hair long, curved, fluffy, yellowish white. Skin largely black, the untufted segments with orange-yellow warts; pale yellow lateral and subventral bands. Thoracic feet black. Later the long hair becomes yellow.

Stage V.-Head high, black, epistoma white; width, $3 \mathrm{~mm}$. Body ocherous, brownish on the warts, a black band dorsally and marks on the sides, all covered and partly concealed by long, curved, fluffy, yellowish white hairs. Dorsal black pencils present on joints 5,7 to 10 , and 12 , those of 7 to 10 progressively smaller.

Stage VI.-Head bilobed, oval, shining black; width, $4 \mathrm{~mm}$. Body olivaceous, ochraceous, shaded with black more or less, especially over the dorsum, or nearly all black, entirely covered and nearly concealed by the long, fluffy, curved, yellow-white secondary hair. Black pencils present on joints 5, 7, and 12 or on 8 and 9 also, but short, not longer and subordinated to the other hair. In the previous stage the hair was straighter and only long laterally; now it is long all over and curved like that of vulpina. Later the hair becomes darker yellow. Most of the larvæ have the body yellow with a dorsal and two side stripes of black, venter and feet black.

Cocoon spun on wood with pieces bitten off to reinforce it. The hair and body turn dark before spinning.

APATELA LEPORINA Linnæus, var. MOESTA Dyar.

Six specimens, June 13, July 2, 21, 27. A very distinct form of the European species. The color is dark gray, fully as dark as canadensis Smith and Dyar, which it much resembies; but the basal line is broken and the transverse posterior line is dentate as in eastern leporina. The larva agree in type with leporina, but the head is darker, often strongly marked with black. None of the American forms of leporina agree exactly with the European. We seem to have three races, which $\mathrm{I}$ would list as follows:

A patela leporina Linnæus

Europe.

variety iulpina Grote

Northern Atlantic coast.

variety cretata Smith

Mountains of Colorado.

variety moesta Dyar

Eastern British Columbia. 
Egg.-Circular, flat, the center dome-shaped but without a strongly flattened rim. Ribs about 75 around the margin, decreasing irregularly and at several points by alternation or confluence, coarsely waved or even circularly joined by broad, shallow pittings representing the obsolete reticulations, cross striæ low, coarse, rounded bars; vertex finely reticulate. Pale green, the center retracted, leaving a broad, colorless edge. Diameter, $1.6 \mathrm{~mm}$; height, $0.4 \mathrm{~mm}$. Later there appears a narrow, dark-red ring about the middle of the side and a small vertical dot sometimes confluent by one or two bars; still later this marking retracts to a broad, red ring, scalloped on the outside. Hatched in nine days.

Stage I.-Head rounded, bilobed, shining black, mouth parts pale. Body moderate, equal; feet normal, white with dark brown dorsal patches on joints 4-5, 7-9, and 12-13 anteriorly. Cervical shield large, black. On thorax tubercle $\mathrm{ia}+\mathrm{ib}$, on abdomen i with two large equal hairs, the rest single; no subprimaries. Warts concolorous with the marks; hair all black. Skin sparsely minutely granular, not conspicuously so.

Stage II.-Head round, bilobed, more or less black shaded all over or the paraclypeal streak heavy and black; width, $0.6 \mathrm{~mm}$. Body moderate, joint 11 weak; white, light brown dorsally on joints 2, 4-5, 7-9, 12-13 anteriorly except the warts, which are white; hairs black and white, long, soft; feet pale.

Stage III. - Head white, a black band bordering the paraclypeus with dottings outwardly or largely black, only clypeus above, dot on vertex and sides of lobes white; width $1.2 \mathrm{~mm}$. Body white, a faint brownish lateral shade; joints 2, 4, 5, 7, 8, 9 and 12 stained with brown especially about wart $i$, and with black dorsal hairs, the other hairs almost entirely white, rather long. Few, if any, secondary hairs. Wart $\mathrm{i}$ on the dark segments black, the rest white, moderate, raised; feet pale. In some the body is all shaded with violaceous, even partly so on the pale segments, but the warts there are white. Thoracic feet black.

Stage IV.-Head shining black, clypeus, mouth, a small spot on vertex and irregular patches above eye white; hairs whitish; width 1.8 to $2.2 \mathrm{~mm}$. Body moderate, equal, white, largely shaded with brown on the back and sides between the warts. Cervical shield black, with white bristly hair. Joints 5, 7-9, and 12 brown dorsally, with brown warts and long unpaired dorsal black hair pencils. Other hair long, white, rather thin, fluffy, straight, both primary*and secondary about equal. On joints 3 and 4 wart $\mathrm{i}$ is black; other warts white.

Stage V.-Head white, with black paraclypeal bands; width $2.8 \mathrm{~mm}$. Hair white, long, fluffy, concealing the body; black pencils present on joints 5, 7, 8, 9, and 12. Most of the larvæ are white, some yellow, and then markedly darker, with more black on head and dark color on 
body. Some have a black tuft on joint 6 , though small, and a few black hairs on joints 3 and 4 .

Stage VI. - Head white, more or less marked with black; width 4.5 mm. Body greenish white, immaculate or shaded with sordid brownish, with black dorsal marks. No pencils, all the hair fluffy white or yellow, soft, curled, abundant, the secondary predominant; warts small, inconspicuous.

\section{APATELA INNOTATA Guenée, var. GRISEOR Dyar.}

Sixteen specimens, June 13, 16, 23, 25, 30, July 4, 19, 30. A western variety of innotata, slightly larger, the white ground color more distinctly strewn with black scales and the black marks bordering the usual lines sharper and more pronounced, especially noticeable in the transverse anterior line, which in innotata is almost lost; in griseor it is often nearly as obvious as the transverse posterior line.

Egg. - Flat, moderately arched, no rim, the edge rather steep; about 56 ribs, diminishing in the middle of the side and again toward vertex, irregularly ending about the micropylar area, which is shagreened; wavy, moderate, no reticulations. Bluish green. Diameter $1 \mathrm{~mm}$, height $0.4 \mathrm{~mm}$.

Stage I.-Head cordate, translucent, whitish; mouth pointed. Body white, the food showing green, tubercles not large, elevated, concolorous; hairs long, fine, white, the dorsal ones coarse, all single, no subprimaries; on thorax ia+ib, iib small.

Stage II.-Head round, bilobed, a little elongate, whitish; width $0.5 \mathrm{~mm}$. Body normal, warts prominent, with one or two long and several short hairs, the latter with enlarged tips; all transparent whitish, food green, the male glands showing white; traces of a white subdorsal band beneath wart ii in spots. Hair all pale; no shields.

Stage III. - Head deeply bilobed, flattish before, green; width 1.2 mm. Body uniform, joint 11 weak, with smaller warts. All green, warts $\mathrm{i}$ and ii whitish. Warts round, elevated, bearing a long, dark hair and many small, short, pale ones, with enlarged tips, except subventrally, where all the hairs are simple. Wart ii large, iv small, stigmatal posteriorly; the two upper thoracic warts (ia + ib and iia) approximate. Later there is a faint brownish dorsal spot between tubercles $\mathrm{i}$ on joints $5,8,9$, and 12 .

Stage IV.-Head green, mottled with brown spots over the lobes in front; width $1.8 \mathrm{~mm}$. Body with joint 12 slightly enlarged; warts with a few long hairs and many short truncate-tipped ones, subventral hair feathered. At first marked as before. Warts i to iii yellow, the yellow of $\mathrm{i}$ and ii confluent and inclosing red-brown spots on joints 5 to 12. largest on 5, 8, 9, and 12. Traces of a yellow dorsal line between. No secondary hairs dorsally, but several fine ones subventrally. Later the dorsal markings become yellow spots with red- 
brown centers, absent on joints 2 and 3 , small on 4 , covering wart ii on $5,8,9$, and 12 , covering $\mathrm{i}$ only on joints 6,7 , and 10 , just to wart ii on joint 11 by a branch, absent on 13 .

Stage V.-No change. Width of head $2.6 \mathrm{~mm}$.

Stage VI.-Head green, the upper half thickly covered with angular black spots, a small light red patch on vertex of each lobe; antennæ black ringed, setæ white; width $3.8 \mathrm{~mm}$. Body moderate, equal, joint 12 a little enlarged dorsally. Warts small, reduced, consisting of a group of few tubercles. Secondary hair present on sides and subventrally, longer below. Olivaceous blackish, black granular on a dark olivaceous ground. Warts i, ii, and iv black, with pale tubercles, iii and v light green, vi dusky; slight greenish dilutions subdorsally below tubercle $\mathrm{i}$ on joints $5,8,9$, and 12 . Hair black and white, the secondary hair mostly white. Spiracles white, black rimmed; no defined markings.

The larvæ in this stage closely resemble the bark of birch, on which they were fed.

\section{APATELA MINELLA Dyar.}

One specimen, June 13. No female was obtained, so the life history remains unknown. I had suspected that this species was the western form of fragitis Guenée, but I have normally light colored fragitis from Wellington, British Columbia (G. W. Taylor), on the coast. A series of specimens is required to form a definite opinion.

APATELA GRISEA Walker, var. REVELLATA Smith.

Twenty specimens, June 13, 16, 18, 19, 30, July 2, 8, 15, 19, 21, 29 (Bear Lake). This form is generally larger and darker than eastern grisea, as usual with western forms, but not specifically distinct, I think. Some of the moths are nearly as pale as normal grisea. The larvæ, too, are the same.

Egg.-Nearly hemispherical, not much flattened, no rim, the sides perpendicular, domed. Ribs, about 60 , waved, smooth, no reticulations, diminishing above, forming an irregular ring around the micropyle, which is shagreened. Pale bluish green. Diameter, $0.9 \mathrm{~mm}$; height, $0.45 \mathrm{~mm}$. Hatched in seven days, without change of color.

Stage I.-Head, bilobed; mouth, broadly projecting; eye, black; jaw, brown. Body, uniform, joint 12 a little enlarged, white, immaculate; hair, white, spinulose; hairs i to iii, long, fine; iv and v, shorter, weak. Hairs all single, no subprimaries, ia $+i b$ on thorax. No shields; tubercles, concolorous, all pale and transparent. Dorsal warts, conically elevated; feet, equal. Later joints 2, 5-6, 9-10, and 12 have diffuse violaceous dorsal patches. Still later purple brown spots appear, small, rounded, covering tubercle ii only, on joints $2,4,5$ (the one on 4 smaller than that on 5), 8, 9, and 12. Warts, white, except in the dark spots. 
Stage II.-Head with the apex subangular, flat before, whitish, stained with brown streaks above the clypeus; mouth, reddish; width, $0.6 \mathrm{~mm}$. Body, moderate, flattish; warts, large conical, concolorous. White, an obscure white, subdorsal line edging the dorsal purple brown spots on joints $2,4,5,8,9$, and 12 , with a slight subdorsal spur to joint 11. The food shows green. Each wart has one long and several short hairs; in the brown spots some of the short hairs are black with enlarged tips. Skin, granular; feet, all pale.

Stage III.-Head, angularly bilobed, washed with brown all over the lobes, especially on the angles; clypeus, green; antennæ, white; width, $1 \mathrm{~mm}$. Body, cylindrical, moderate; warts, prominent, with fine long and other short hairs. Hairs, sparse, the dorsal ones mostly blackish. Green, translucent, a white subdorsal band edging the patches of purple brown on joints $2,4-5,8-9$, and 12 , that of joint 2 diluted with green behind. The patch on joint 4 is smaller; that on 12 extends a subdorsal arm onto joint 11 . Feet, green.

Stage IV.-Head, high, strongly bilobed, green on face, vertex, and sides, all shaded with dark brown mottled on a pale ground; width, $1.4 \mathrm{~mm}$. Body with joints 5 to 7 prominent, 12 enlarged dorsally, sides perpendicular. Warts, round, prominent, concolorous with the markings. Green, joint 2 subdorsally, 4-5, 7-9, 11 subdorsally, 12 dark brown between a pair of yellow subdorsal lines, which widen at 4-5 and 8-12. Warts with several long hairs and a few short ones.

Stage V.-Head thickly washed with purple on a white ground and a little white behind, only the clypeus green, antennæ white; width, $2.2 \mathrm{~mm}$. Body hunched, sides high, perpendicular, joints 5 and 12 a little enlarged dorsally. Green, a purple brown dorsal band, wide on joint 2 and green diluted, wide on 5 , narrow on $6-7$, very wide on 8-12, oval, including a green spot on 11-12 anteriorly, which cuts into the yellow edging on joint 10 and surrounds tubercle $i$ on joint 11; joint 13 faintly marked. Warts concolorous with the markings; feet, green. The sides appear shaded by minute black spicules; there are brown spots at the spiracles and tubercle vi; some secondary hair subventrally.

Stage VI.-Head round, flattened, erect, vertex in joint 2, lobes purple brown, mottled with dark in front, clypeus green, sides whitish behind the eyes; width, $3.1 \mathrm{~mm}$. Body robust, compressed, joints 4-7 highly arched, 12 prominent, dorsally bearing conical warts i and ii on a quadrate platform. Warts rounded, reduced, but the dorsal ones prominent; few haired, not dominant, a few secondary hairs subventrally, especially on the leg bases. Green, a dorsal purple brown stripe wide on joint 2 , over tubercle $\mathrm{i}$ on joint 3 , triangularly widened to $\mathrm{ii}$ on 5 , to $\mathrm{i}$ only on $6-7$, elliptically widened on $8-12$, inclosing a green space on 10-11 anteriorly, reaching the anal plate; yellow edged. 
Brown spots around the spiracles and above tubercle vi. A few whitish mealy dots on the sides; feet, green.

The larvæ were fed on birch.

\section{APATELA MANSUETA Smith.}

One specimen, July 21. I greatly regret that the life history of this pretty species was missed. Mr. Cockle captured a female specimen, now in his collection, but unfortunately killed it before noting its identity.

\section{APATELA DISTANS Grote, var. DOLOROSA Dyar.}

Three specimens, June 16, 19, 25. I have another from Rossland, June 3, 1899 (W. R. Johnson). The specimens are darker than eastern distans, both in the tone of the gray ground and the amount of black shadings. The larvæ seem to vary more in color than eastern larvæ, but this may be because I have a larger series of the western form. The red subventral shade, so conspicuous in eastern distans, is lacking in all my specimens.

Egg.-Flat, circular, low domed, laid singly or in groups partly overlapping. Ribs, about 60 around the margin, diminishing by alternation toward the vertex, distinct, finely waved, almost beaded; diameter, $1.1 \mathrm{~mm}$; height, $0.3 \mathrm{~mm}$.

Stage 1.-Head shining black, mouth brown. Body whitish, joints 2 to 10 clear vinous dorsally, 11 weak, white, 12 and 13 brown. Warts large, blackish; i many haired, ii to $\mathrm{v}$ single, vi absent; leg shields faintly infuscated bearing a hair; on thorax tubercles ia and ib joined at base, iib small, separate, no subprimaries. Feet pale. Hairs blackish, spinulose, cervical shield infuscated. Later only joints 5, 8,9 , and 12 are vinous red, the other segments fading to white; the red brown marks are sharply edged and there are slight angular ones on the white segments.

Stage II.-Head bilobed, angular, shining black; width $0.6 \mathrm{~mm}$. Body robust, the dorsum serrate by the projecting tubercles; sordid white on the sides and on joints 10, 11, and 13. Dorsal warts broadly dark vinous, joints 5, 8-9, and 12 marked with the same color. Hairs black, rather bristly. Later a continued dark dorsal stripe and subventral mottlings; area about tubercle iii of joints $3-4,6-7,10-11$ white. The larva tapers behind; joint 12 is prominent dorsally.

Stage III. - Head bilobed, apices sharp, median suture depressed; shining black; width $0.8 \mathrm{~mm}$. Body robust, joints 5 and 12 a little elevated; warts large, black, hair thick and bristly, black with a few pale ones intermixed. The body is mostly dark, lighter between the warts on joints 6,7 , and 11 . Feet all dark.

Stage IV.-Head rounded quadrate, flattened before, shining black; width $1.5 \mathrm{~mm}$. Body black except subdorsally on joints 6-7 and 10-11 where it is diluted yellowish. Warts round, black, elevated; hair 
black, bristly, rather even, some of it white about the dilutions and subventrally; none secondary. Feet dark. Hair of joints 5 and 12 rather denser than elsewhere. In some specimens all the central hair on joints 6 to 11 is ocherous; another had the hair all brown, tipped with black.

Stage V.-Head black; width $2.1 \mathrm{~mm}$. Body and warts black, the dorsal space rather widely bare. Hairs at the ends partly or wholly black, the central ones dull foxy red, variable. The pale subdorsal patches are gone. Hair rather soft, of irregular length, some of the end ones longer.

Stage VI.-Head bilobed, rounded, shining black, epistoma and bases of antennæ white; width $3 \mathrm{~mm}$. Body equal, joint 12 scarcely enlarged; velvety black throughout. Warts large, round, shining grayish by whitish rings about the hairs, i very large, remote, leaving a rather wide dorsal space. Hairs from tubercles $i$ and ii on joints 4 , 5 , and 12 light foxy red, the rest bluish black, stiff, bristly, but mixed with softer spinulose ones. Other specimens have red brown hair the whole length, mixed with some blackish and a faint reddish shade along the subventral fold intersegmentally. All have wart i partly white, joint 12 subprominent dorsally. In some the hair is all black, while one had it white with red hair on joints 5 and 12 .

\section{APATELA PERDITA Grote.}

Three specimens, June 13, 16 . The species is a very distinct one. Mr. Cockle had not taken it till this season, though I have several from Rossland taken in June, 1899, by Mr. W. R. Johnson.

Egg. - Shape of half of a sphere, base broadly flat; about 50 waved ribs diminishing along the middle and again near the vertex, broadly triangular in section, irregularly waved; surface else minutely granular shagreened. Whitish, later all reticulate in dark red. Diameter, $1.3 \mathrm{~mm}$; height, $0.7 \mathrm{~mm}$.

Stage I.-Head round bilobed, mouth large, antennæ short, black over vertex, shading to brownish below; epistoma and antennæ white. Body cylindrical, normal, whitish, a vinous shade from within except on joints 10 and 11 . Warts moderate, blackish, i many haired with large and small hairs, the rest single, no subprimaries. Thorax with $\mathrm{ia}+\mathrm{ib}$, iib small, vi single haired on joints 3 and 4 . Cervical shield small, blackish. Later only joints 5, 7-9 and 12 are vinous red, the other segments greenish white.

Stage II.-Head sharply bilobed, shining black, mouth and antennæ sordid white; width, $0.5 \mathrm{~mm}$. Body robust, with large warts close together; joint 12 a little enlarged, 11 weak. Dark vinous brown, joints 6 and 10 pale, 11 decidedly pale. Hair black, the lateral ones paler. All the warts dark; feet black. 
Stage III. - Head rounded quadrate, shining black, mouth whitish; width, $0.75 \mathrm{~mm}$. Body with joint 5 prominent, 12 enlarged dorsally. Whitish, largely overlaid with purple black, joints 6,10 and 11 are pale, the warts pale with dark color infiltrated between; other warts black. Hairs stiff, black, only a few white except on the pale segments. Hairs of tubercle $\mathrm{i}$ on joint 12 subpencilled, erect. Thoracic feet black ringed, abdominal ones pale.

Stage IV.-Head shining black; width $1 \mathrm{~mm}$. Body cylindrical, warts moderate, joint 12 slightly enlarged. Black, marked with white, which is cut into streaks and spots on joints $3,6,10,11$, and 13 ; a white subventral stripe. Warts black; hair black except some white ones which are mostly shorter, from the pale parts. No secondary hairs.

Stage V.-Head shining black; width, $1.4 \mathrm{~mm}$. Body all black, densely covered by the bristly black hairs, no open dorsal space. On joints $3,4,6,10$, and 11 there are also intermixed fine soft wavy white hairs, some of the bristles here also white. Subventral hairs largely white and longer. Joints 5 and 12 rather prominent.

Stage VI. - Width of head, $2.3 \mathrm{~mm}$. All black, joint 12 prominent. Hairs of joints 5 and 12 dorsally deep black, of 4 and 6 mixed with feathered white, the rest mostly white but mixed with black, bristly, irregular, rather dense; some long pale hairs subventrally; spiracles white.

Stage VII.-Width of head, $3.5 \mathrm{~mm}$. Black, the segmental incisures 3-4 and 4-5 exposed in the warning attitude; joints 5 and 12 prominent. No change from the previous stage; warts black; hair bristly, rather dense, black on joints 5 and 12, elsewhere black mixed with ocherous white, distinctly ocherous on joints 4 and 6 , weaker on joint 11. Some long hairs at the ends. Some of the hairs are softer but hardly spinulose, most noticeable on the prominent segments. Warts i of joints 6 to 11 more or less white.

\section{APATELA EMACULATA Smith.}

One specimen, July 29 (Bear Lake). This is very close to distans var. dolorosa, and may prove to be the same. It is, however, a smoother gray, without the contrasts of light and dark shades, the transverse posterior line is less distinctly dentate, and there are other slight differences. Therefore I keep them separate until more material is at hand. My specimen agrees closely with Smith's type from Easton, Washington (Koebele).

APATELA IMPLETA Walker, var. ILLITA Smith.

Thirteen specimens, June 2, 13, 16, 18, 19, 23, 25, July 19 . This form was described as a distinct species, but is better placed as a western race of impleta. The specimens are generally darker than the 
eastern form, Smith's male type before me being much darker; but others are not so dark, some being practically as light as normal impleta and nearly indistinguishable therefrom. The larva, too, is close to the eastern one. It is this larva to which I referred in the description of stage $\mathrm{v}^{a}$ of huteicoma (=impleta) as "Californian examples."

Egg. - Shape of half of a sphere, not broadly flattened; domed, laid singly or in groups, partly overlapping. About 80 vertical ribs, diminishing toward the vertex, moderate, sharp, rather high and narrow, waved, joined by narrow low cross-striæ. The ribs run practically to vertex, becoming confused. Yellowish white, later with little red dots rather thickly scattered. Diameter, $1.2 \mathrm{~mm}$; height, $0.6 \mathrm{~mm}$.

Stage 1.-Head cordate, black above, shading to whitish about the mouth, jaws brown. Body whitish, dorsum broadly dark vinous, except joint 11 and the anal feet. Hair long, black, curved; wart i large, many haired, the rest single with no subprimaries; iv and $v$ with smaller hairs. On thorax tubercles ia + ib; joint 11 weak, its wart $\mathrm{i}$ many haired, but small. Later the larva is white, cervical shield transverse, black; joints 4 posteriorly-5, 8, 9, 12 with large dorsal spots. Warts all black, except those on joint 11 . The dark patch on joint 12 is infiltrated by pale.

Stage II.-Head cordate, pale, the apices of the lobes black; width, $0.5 \mathrm{~mm}$. Joints $3,6-7,10$ posteriorly - 11 greenish, the other segments and all the warts dark, vinous blackish. Hairs black dorsally, pale subventrally, straight and stiff. Feet pale. The sides below wart iii are entirely pale.

Stage III.-Head rounded, quadrate, shining black, paraclypeus whitish, labrum and antennæ narrowly pale; width, $0.9 \mathrm{~mm}$. Body purplish black over dorsum, sides of joint 11 pale and showing a white, subdorsal band; subventral region and feet pale; thoracic feet blackish. Hairs black dorsally, whitish subventrally, rather dense, spinulose, joint 5 with heavy dorsal tuftings, and 6 with short pale hairs; hairs of tubercle $\mathrm{i}$ of joint 12 penciled, short, plumose. Hair of joint 11 short and mostly pale.

Stage IV.-Head bilobed, shining black; width, $1.5 \mathrm{~mm}$. Body black dorsally, dotted on the sides, whitish subventrally and on anal feet; a pale yellow subdorsal bar on joint 11 covering wart ii. Warts round, black, distinct; no secondary hair. Black and white fanshaped tuft on joint 5, a smaller white one on joint 6 , a pair of erect subdorsal pencils on joint 12 black. White hairs over the head and subventrally. Thoracic feet black, abdominal ones pale.

Stage V.-Head bilobed, shining black, a white mark in paraclypeus, epistoma and labrum whitish; width, $2.5 \mathrm{~mm}$. Body black 
dorsally, whitish subventrally and on feet, lateral warts pale. A yellow bar on wart ii of joint 11 , a pale yellow stripe along wart $\mathrm{v}$. Hairs whitish, mostly thin but tufted in dorsal fans, black on joint 5 , white on 6 and 5 laterally and slightly on 4 ; a black subdorsal pencil on 12 and small white tuft below it. Joint 12 somewhat enlarged. Later the subdorsal stripe and subventral band are more or less dark red. One had the tufts on joint 5 brown, those of 4 and 6 pinkish ocherous.

Stage VI.-Head black, paraclypeus, epistoma, edges of labrum white; width $3.2 \mathrm{~mm}$. Subdorsal stripe on joints 10 and 11 at tubercle ii and subventral band at tubercle $\mathrm{v}$ deep red shaded. Body black dorsally, dotted and streaked with white on the sides. Fan tufts on 3,4 , and 6 creamy white, that on 5 larger and pale brown; divaricate pencils of joint 12 black with white ones below. Other hair mostly white. All as before.

Stage VII.-Width of head, $4 \mathrm{~mm}$. No change from the last stage. Stripes, deep crimson; body black with white markings, tufts of warts $\mathrm{i}$ and ii of joint 5 black or cream color, of iii on joints 5 , 4, and 6 cream color, of i on joint 12 black with cream color below. Other hairs pale.

Cocoon of silk between leaves.

\section{MEROLONCHE LUPINI Grote.}

No specimens. One in Mr. Cockle's collection is labeled spinea Grote and seems intermediate between that and hupini, for the ordinary spots are distinct, and so, too, is the median shade, which is black and angulated in the middle.

\section{PANTHEA PORTLANDIA Grote.}

No specimens; one from Mr. Cockle's collection is before me.

PANTHEA GIGANTEA French.

No specimens. One from Mr. Cockle's collection, collected August 13,1902 , is a female and expands only $45 \mathrm{~mm}$.

\section{RAPHIA FRATER Grote.}

No specimens; one from Mr. Cockle's collection, June 2, 1902. The form is similar to that which I have from Easton, Washington (Koebele). Like Gluphisia spetentrionalis, discussed later, this species feeds on the aspen and cottonwood, and its range is coextensive with its food plants. As with the Gluphisia, Raphia runs to a variety of local forms, exactly paralleling the forms of Gluphisia and conditioned by the same differences in environment. Prof. J. B. Smith has lately conceived the idea of treating all these forms as distinct species, exactly as the late Henry Edwards did with Gluphisia twenty years ago. But 
such a course does not properly indicate the relationships of the forms. The names coloradensis Putnam-Cramer, pallula Hy. Edwards, and cinderella Smith will be referred as varieties of frater Grote. The form from Kaslo and Easton, Washington, alluded to above, is very similar to typical frater, but is a little darker shaded on the basal and inner portions of the forewing.

HADENELLA TONSA Grote.

One specimen, August 8, and three from Mr. Cockle's collection, July 31, 1901, August 20, 1903, and September 6, 1902. The specimens agree with the type of subjuncta Smith before me. In Bulletin 52 , U. S. National Museum, I referred subjuncta as a synonym to minuscula Morrison; but I learn from Doctor Smith that this is an error, and that subjuncta is realy synonymous with tonsa Grote.

\section{PLATYPERIGEA ANOTHA Dyar.}

One specimen, August 22 (Revelstoke). Mr. Cockle has another, pale and somewhat faded.

\section{PLATYPERIGEA PRÆACUTA Smith.}

No specimens. One from Mr. Cockle's collection, August 19, 1901, closely resembles the type before me, except that the transverse anterior line is heavier, the spots more distinct, and the dark shade at anal angle less distinct.

\section{CARADRINA MERALIS Morrison.}

Twenty-three specimens, August 1, 6, 11, 13, 15, 16, 17. The specimens are all dark gray, with the ordinary spots black-filled and contrasting, hind wings more or less gray shaded, even in the males. They differ from the meralis in the National Museum collection (Rhode Island, Colorado), in being rather darker, with the ordinary lines and terminal shade better defined. The form seems scarcely specifically distinct from extimia Walker.

\section{CARADRINA EXTIMIA Walker.}

Seven specimens, July 10, 24, August 15, 17, and one from Mr. Cockle's collection, July 10. The larva is darker than that of extimia from Colorado, but otherwise exactly like it. I have already given the life history. ${ }^{a}$

\section{CARADRINA MIRANDA Grote.}

One specimen, June 24, and one from Mr. Cockle's collection, June 11. The specimens are large and grayish powdery, but not specifically distinct from miranda, I think. 
CARADRINA NITENS Dyar.

Four specimens, June 25, July 4, and one from Mr. Cockle's collection, June 7. This is a larger and blacker form than miranda.

PERIGEA VETERATA Smith.

No specimens, but one from Mr. Cockle's collection.

OLIGIA FESTIVOIDES Guenée.

One specimen, June 13.

HADENA CURVATA Grote.

One hundred and seventy-two specimens, June 25, July 12, 14, 19 , $25,27,30$, August $5,6,7,12,13,17$. This has been referred as a synonym of binotata Walker, by Mr. Grote himself. However, binotata was described from Vancouver Island and my specimens from there (Wellington, Rev. G. W. Taylor; Victoria, Mr. A. W. Hanham) differ in the greater size of the pale patch beyond the reniform, in which the transverse posterior line is nearly lost. Walker seems to be referring to such a character in his description when he says "reniformi magna ochraceocinerea." Grote says of Walker's type: "It is rubbed, very dark, with the pale brown reniform contrasting." Curvata was described from Mendocino County, California, and Grote says in reference to this marking: "ochery brown * * * always stains the approximate transverse posterior line opposite this [reniform] spot. * * * I I think this applies more nearly to the form before me, in which the pale patch is small and distinctly traversed by the transverse posterior line. I have this same form from the Sierra Nevada Mountains of California (Coll. J. B. Smith) and Placer County, California (Koebele). The latter specimens were named adnixa, but wrongly so, I judge, as that species is described as paler and more variegated than curvata, and comes from Nevada and other arid regions.

Eggs from captive females were difficult to obtain and proved sterile; but full grown larvæ occurred to us on the wild currant (Ribes sanguineum).

Egg.-Slightly spheroidal, nearly spherical, without basal flattening; smooth dark yellow, the surface flattened in small hexagonal areas without raised reticulations or any trace of ribs, minutely shagreened; diameter, $0.8 \mathrm{~mm}$.

Larva.-Head erect, vertex in joint 2 ; green, faintly white dotted on the lobes, antennæ and mouth pale; width $2.6 \mathrm{~mm}$. Body cylindrical, normal, joint 13 a little attenuated behind, 12 very slightly humped. Green streaked, dotted with yellow, shields concolorous, uncornified; dorsal line white, distinct from joint 2 anteriorly to 13 posteriorly, widened a little on the posterior slope of joints 12-13; 
subdorsal line yellow, broken, dotted, waved upward a little on the centers of the segments, especially so on joint 12; substigmatal line yellow, narrowly linear, just touching the lower edges of the spiracles throughout, distinct and whitish on the anal foot. Feet green. The dorsal and subdorsal lines are distinct on joint 2. Spiracles white, black rimmed. The substigmatal line is edged with red above narrowly, especially on joint 12.

\section{HADENA DIVESTA Grote.}

No specimens; one from Mr. Cockle's collection was labeled Chytonix palliatricula Grote, to which species it bears a slight resemblance.

HADENA REMISSA Hübner.

No specimens; one in Mr. Cockle's collection, July 21, 1901.

HADENA IMPULSA Guenée.

No specimens; one in Mr. Cockle's collection, July 8, 1902.

HADENA BARNESII Smith, var. SORA Smith.

Nine specimens, June 30, July 8, 19, 25, August 5, 15, and two from Mr. Cockle's collection July 18, 1901, August 22, 1901. The specimens agree excellently with Smith's description of sor $a$. I do not see in the form anything but a dark variety of barnesii from Colorado and Wyoming, types of which are before me.

\section{HADENA VERSUTA Smith.}

Seventeen specimens, July 2, 19, 24, 25, 27, 30, August 1, 12,16 , and one from Mr. Cockle's collection July 25, 1902. Another specimen in Mr. Cockle's collection is labeled Hadena ducta, and is, indeed, so much like it as to suggest that versuta is but a western form of that species. Still another specimen is marked Hadena lona Strecker, but evidently incorrectly when compared with authentic specimens of that species. Eggs were obtained from captive females.

Egg.-Laid singly. Spherical, the base broadly flattened and strongly adherent. Ribs about 48, straight, narrow, parallel, running nearly to the summit before decreasing in number, crested by vertical reticulations, but without any in the hollows, the cells rounded quadrangular, waving the ribs a little. Vertex reticulate, microplye slightly raised. Pale, slightly greenish yellow; diameter $1 \mathrm{~mm}$. Later washed with red over most of the vertex.

Stage I.-Head rounded bilobed, shining pale luteous with brown spots at the tubercles, eye black, mouth brown. Body moderate, joint 12 enlarged, feet of joints 7 and 8 much shortened. Tubercles large, 
round, black, low elevated. Shields concolorous with the black tubercles; feet pale, whitish; skin minutely sparsely dark granular.

Stage II.-Head round, shining pale green; width, $0.7 \mathrm{~mm}$. Body slender, rather elongate, feet of joints 7 and 8 short, joint 12 slightly enlarged. Translucent pale green, no marks, no shields, very faintly indicated dorsal and subdorsal pale lines. Tubercles minute, setæ moderate, rather stiff, black.

Stage III.-Head shining green, ocelli black; width, $1.05 \mathrm{~mm}$. Body rather slender, feet of joints 7 and 8 shortened, joint 12 enlarged dorsally. Soft green, dark dorsally, pale subventrally; dorsal and subdorsal lines narrow white, the stigmatal line broader, white, edged with dark green above. Feet green; no shields; tubercles white with black hair dots.

Stage IV.-Head rounded, the apex in joint 2, shining green, luteous tinted; width $1.6 \mathrm{~mm}$. Body cylindrical, joint 12 not enlarged, the feet equal. Translucent green, dotted with white, the incisures folded yellowish. Dorsal line narrow, subdorsal more distinct, broken, dotted white, edged by a space from which the white dots are absent. Stigmatal line broad, white on its dorsal edge, diffuse and fading below, covering the spiracle except on joints 2 and 12 . Feet green; tubercles white with black hair dots; setæ minute.

Stage V.-Head greenish luteous, shining, faintly brown tinted above and vacuolated by the greenish ground; width $2.2 \mathrm{~mm}$. Dorsum pale brown to the spiracles by thick brown and whitish dots on the green ground color; dorsal line obscure, white, dark edged, a dark spot on tubercle i; subdorsal line finely dotted, faintly dark edged; stigmatal line narrow, white, passing below the spiracle on joints 2 and 12 ; subventral region green with white dots. Feet pale; spiracles white with black edge; thoracic feet a little smoky; tubercles white with dark hair dots, obscure; setæ short and fine.

Stage VI.-Head rounded, wider than high, shining greenish luteous, reticulate in pale brown, the ground showing as rounded dots; width $3.1 \mathrm{~mm}$. Body moderate, joint 12 slightly enlarged, feet equal, no shields. Mottled with brown and dotted with whitish on a pale green ground to the spiracles, subventral region green with white dots, the dorsum appearing greenish brown, the venter green. Dorsal line whitish, dark edged, the edges macular in the incisures, tubercles $i$ and ii with brown spots above; stigmatal line narrow, white, vacuolar, passing below the spiracle on joints 2 and 12; feet green like the subventral region; tubercles small, whitish; setæ small.

HADENA FINITIMA Guenée, var. CERVIANA Smith.

Four specimens, June 8, 13, 23, July 8. In Bulletin 52 of the U.S. National Museum, I referred cerviana as a variety of the European basilinea Fabricius on the strength of a specimen labeled for me by 
Prof. J. B. Smith. But Professor Smith maintains the distinctness of these species, ${ }^{a}$ though he admits cerviana to be the northwestern representative of the eastern finitima, and I accordingly so refer it.

\section{HADENA LONGULA Grote.}

One specimen August 11, much worn and faded; also one from Mr. Cockle's collection September 18, 1901.

\section{HADENA REMISSA Hübner.}

Two specimens, July 19, August 5.

\section{HADENA VULTUOSA Grote.}

One specimen, July 27, and one from Mr. Cockle's collection.

\section{HADENA LATERITIA Hübner.}

Sixteen specimens, July 25, 27, 30, August 6, 16, 18.

\section{HADENA DUBITANS Walker, var. COGITATA Smith.}

Four hundred and thirty-two specimens, June 21, July 14, 24, 27, 29 (Bear Lake), 30, August 5, 6, 7, 12, 16, 17. Many of the specimens are light, nearly like Smith's type of cogitata, but they run darker also, the darkest fully matching the ordinary dubitans of the East. This is not a racial distinction, as eastern specimens are sometimes light. The name cogitata can be used to designate the variation.

HADENA MAIDA Dyar.

Nine specimens, July 25, 27, August 4, 6, 12, 17.

\section{HADENA DEVASTATRIX Brace.}

Eight hundred and fifty-two specimens, July 21, 27, August 3, 4, $6,7,11,12,13,15,16$. Although this species and dubitans were very common, it was impossible to obtain the life history of either, though efforts were made to do so. The captive females refused to deposit eggs.

\section{HADENA ARCTICA Boisduval.}

Sixty-five specimens, July 4, 19, 27, 30, 31, August 6, 7, 16, 17, 18. This species, like the preceding, refused to deposit eggs.

\section{HADENA PLUVIOSA Walker.}

Three specimens, July 21, August 11, September 10 (Banff, Alberta). Apparently distinct from arctica Boisduval, but very close to it. 
HADENA RELECINA Morrison.

No specimens; one from Mr. Cockle's collection, September 19.

POLIA EPICHYSIS Grote.

Two specimens, August 16, 18, and one from Mr. Cockle's collection, September 1, 1902. I now regard this as a distinct species from theodori Grote.

\section{POLIA SANSAR Strecker.}

One specimen, August 6, which I refer here with some hesitation. Strecker described the markings as brown, while mine are black. My specimen is like pulverulenta Smith, but less powdery, a smooth bluish gray.

\section{HYPPA XYLINOIDES Guenée.}

Six specimens, June 13, 25, July 17, August 5, 7. The moths are a little darker and grayer than eastern specimens, with rather less of the brownish shading, while the larvæ are a little lighter than eastern larvæ, more yellowish; but I think there is no specific difference. The male antennæ have the pectinations as in eastern specimens.

Eggs.-Laid singly. Shape of three-fourths of a sphere; a little spheroidal; about 25 low, rounded ribs project a little above the level at the top, crossed by distinct hexagonal reticulations, clear, transparent. Vertex reticulate, micropyle with pyriform cells; pale whitish; diameter, $0.8 \mathrm{~mm}$.

Stage I.-Head round, bilobed, full, shining black. Body equal, normal, joint 12 a little enlarged, joints 5 and 6 also circularly enlarged, feet of joints 7 and 8 small. Cervical shield brown, body white, alimentary canal reddish before. Tubercles small, black; setæ moderate brownish; no marks. Later green from the food, striated with reddish subdorsally and subventrally.

Stage II.-Head rounded bilobed, shining luteous, broadly smoky black over back of lobes; width, $0.6 \mathrm{~mm}$. Body enlarged a little at joint 5 , distinctly so at 12 , feet of joints 7 and 8 rather small. Sordid green, a narrow white dorsal and subdorsal line, the subdorsal one looped up at joint 12; a broad lateral brown shade; substigmatal band broad, faintly whitish; a slight brown shading subventrally. Tubercle dots black; setæ short, pale. Feet pale, the thoracic ones smoky.

Stage III.-Head sordid luteous, shining, dotted with smoky on the tubercles and with reticulations above the eye; width, $0.85 \mathrm{~mm}$. Body contracted at joints 10-11, 12 enlarged dorsally and widened; feet about equal. Yellowish brown, a red brown narrow dorsal lattice; dorsal and subdorsal lines white, narrow. Sides dark brown, especially below; stigmatal band whitish, broad, brown filled, obscure 
except on joint 2 and 12-13, where it forms a bright whitespot. Subventer brown marbled; feet pale.

Stage $I V$. - Head flattish before, shining pale luteous, heavily reticulate in dark brown with a stripe before the eye lighter edged below; width, $1.3 \mathrm{~mm}$. Body narrow from joint 5 to the head, joint 12 much enlarged. Pale ocherous dorsally, a rectangular lattice of dark brown, darker in the incisures; dorsal and subdorsal lines fine, whitish, dotted. Sides dark brown, dotted and reticulate; substigmatal line obsolete except on joints $2-4$ and $12-13$, where it is white. Feet pale; tubercles $\mathrm{i}$ and $\mathrm{ii}$ white, a little elevated.

Stage V.-Head shining, as before, clypeus dark edged, the side stripe broad and white edged below; width, $1.8 \mathrm{~mm}$. Thorax small, joints 5 and 6 a little humped, 12 angularly enlarged both dorsally and laterally. Dorsum light yellow, checkered in brown and marked by lattice work; dorsal line dotted, white; tubercles $i$ and ii white. Sides darker, olivaceous shaded, dotted; a dark brown stigmatal line below which on joints $2-3$ and $12-13$ is bright white, mottled with brown. Feet equal, pale. Subventer more white dotted than the sides.

Stage VI.-Head rounded, the apex in joint 2; shining brown, faintly reticulate with a still darker shade; a lighter line behind the ocelli with pale rings about them; width, $3.3 \mathrm{~mm}$. Body robust, joint 12 enlarged, joints 2 and 3 a little tapered; feet equal. Light yellow brown dorsally, with faint darker lattice darkened to form intersegmental dorsal spots. Tubercle i dark, ii whitish; sides darker, especially intersegmentally, tubercle iii dark; a dark edge to the broad, sordid whitish substigmatal band, reddish reticulate all over; subventral region smokily darkened. Thoracic feet pinkish, abdominal ones like the subventral area, anal feet brown without, with a white line. Tubercles minute, setæ pale, spiracles reddish.

\section{HYPPA INDISTINCTA Smith.}

Three specimens, July 19, 21 (Bear Lake Mountain). I am in some doubt of the determination. Smith described indistincta from one male from Mount Hood, Oregon, which appeared to him to be and probably was aberrant in markings. He has identified as this species a female in the National Museum from Easton, Washington (Koebele). The length of the pectinations of the male antennæ was not stated. Later I identified some specimens from Alaska (Harriman expedition) with the European rectilinea Esper. Recently Smith described brunneicrista from Calgary, Alberta, without any reference to or comparison with rectilinea or indistincta, but with the statement that the male antennal pectinations are longer than in the eastern mylinoides. In all that has been published there is nothing tangible to differentiate indistincta Smith, rectilinea Dyar (not Esper), and brumeicrista 
Smith, and I provisionally regard them as representing one species. Unfortunately, in my specimens, identified as rectilinea, there is but one male, and that without antennæ; neither have I any male in the Kaslo catch, nor has Mr. Cockle one in his collection. Till the contrary is shown it is fair to assume that all have long pectinations, and this will differentiate them from the European rectilinea Esper, in which the pectinations are much shorter than in xylinoides. In all, the patagia are solidly blackish brown without the central lighter bar of xylinoides.

The larvæ are very dark in color, though marked with the same pattern as xylinoides.

Egg. - Shape of two-thirds of a sphere, the base flattened. Ribs about 40, diminishing by confluence, confused into coarse quadrangular reticulations on the summit, the micropylar rosette of cells raised. The ribs have sharp angular summits, the cross striæ are fine, yet distinct, forming cells twice as wide as long. Pale yellow; diameter, $0.8 \mathrm{~mm}$. Laid singly.

Stage I. - Head and cervical shield brown black; thoracic feet, the small round tubercles and leg shields also black. Body whitish, later with a brown stripe between tubercles iii and iv. Setæ short, dark.

Stage II. - Head luteous, brown dotted at the vertex; width, $0.7 \mathrm{~mm}$. Body moderate, joint 12 enlarged, whitish green, dorsal and subdorsal lines white, a broad lateral brown stripe. Tubercles black, moderate; no shields; feet pale.

Stage III.-Head $1.3 \mathrm{~mm}$. Like stage iv of xylinoides, but the dorsal ground pale ocherous greenish, while the lattice marking appears rather as oblique streaks dorsally posteriorly to subdorsally anteriorly, the anterior bars of the lattice being weak. Dorsal and subdorsal lines white dotted, stigmatal band pale the whole length, but white only at the ends. Lateral region nearly solidly dark.

Stage $I V$. - Head shining dull sordid, the brown marks hardly legible; a light side stripe; width, $1.9 \mathrm{~mm}$. Joint 12 angularly enlarged; dorsum brownish white, brown strigose with oblique shades from the posterior dorsal part of the segments, obscure, gathering more solidly forward and downward to cut the pale subdorsal line, which is finely dotted. Dorsal line white dotted, dark edged. Sides more heavily strigose, especially below; a waved brown line above the pale stigmatal space, shading to white on joints 2-3 and 12-13. All below the lateral region white dotted, the lower lateral and subventral ground purplish brown. Feet with dark plates.

Stage V.-Head, $2.2 \mathrm{~mm}$. Very black, nearly all the marks obscured by dull black, all white dotted. Dorsal and subdorsal lines, narrow rows of white dots, the yellowish ground showing in oblique strigose patches in the dorsal space. The stigmatal line shows yellowish at the ends, dotted; also the color is black to the feet; claspers pale.

Stage VI.-Head, $2.9 \mathrm{~mm}$. As in the previous stage. 


\section{EUPLEXIA LUCIPARA Linnæus.}

Eight specimens, June 10, 16, 25, 30, July 14, 19. The life history was observed, but I have previously described the stages, ${ }^{a}$ so will not transcribe my notes.

\section{HELOTROPHA RENIFORMIS Grote.}

One specimen August 18, and one from Mr. Cockle's collection August 24 .

\section{HOMOHADENA BADISTRIGA Grote, var. FIFIA Dyar.}

One specimen July 30, and one from Mr. Cockle's collection July 25, 1902. It differs from the eastern form in being darker gray.

\section{HOMOHADENA COCKLEI Dyar.}

No specimens; one from Mr. Cockle's collection August 13, 1902 (Ainsworth).

\section{ONCOCNEMIS CHLANDLERI Grote.}

No specimens; one in Mr. Cockle's collection August 19, 1902, much rubbed.

\section{RHYNCHAGROTIS GILVIPENNIS Grote.}

Three specimens, July 27, 30, August 6 .

\section{RHYNCHAGROTIS RUFIPECTUS Morrison.}

Five hundred and nineteen specimens, July 14, 19, 22, 25, 27, 30, 31 , August 4, 5, 6, 12,13,15, 17. This large series shows considerable variation, but it does not affect the general appearance of this distinct species. Hampson refers this species to the genus Triphrna.

\section{RHYNCHAGROTIS ANCHOCELIOIDES Guenée.}

One specimen, July 14 . It is larger than the average of placida, yet very doubtfully distinct therefrom, I think.

\section{RHYNCHAGROTIS PLACIDA Grote.}

One hundred and thirty-three specimens, July 2, 4, 14, 15, 19, 24, 25, 27, 30, 31, August 4, 5, 6, $7,11,13,16,17$, and two from Mr. Cockle's collection, July 26, 1902, and August 22, 1901. Extremely variable, from light ocherous brown to blackish gray. Some specimens closely match minimalis Grote from Maine, others are like placida Grote from Colorado, but I can draw no line between them, and I think these names represent forms of one species. Mr. Cockle's 
1902 specimen is a curious aberration of the minimalis form, all the marks lost and replaced by broad, heavy, black subbasal and subterminal bands. Another suffused and nearly illiterate specimen in Mr. Cockle's collection has been named inelegans Smith, but a careful observation shows the orbicular to be closed and the determination to have been hasty.

RHYNCHAGROTIS TRIGONA Smith.

Sixty-three specimens, July 2, 19, 25, 27, 30, 31, August 3, 4, 5, 6, $7,13,15,16,17,18$. Extremely variable, from light ocherous to dark brown. It is nearly allied to placida, but distinguished therefrom by the narrow constricted reniform. The specimens all run darker than Smith's Arizona type before me; only one is as light as it.

\section{RHYNCHAGROTIS VARIATA Grote.}

Two hundred and four specimens, June 16, 21, 23, July 4, 14, 15, $17,19,21,22,24,25,29,30,31$, August 4, 5, 6, 13, 16, 17. This species well deserves its name, as it varies in color from dark vinous red to stone gray. The markings, however, are fairly constant. No larvæ were obtained, though repeated unsuccessful attempts were made to induce the females to deposit eggs.

\section{RHYNCHAGROTIS SCOPEOPS Dyar.}

Five specimens, August 5, 6, and one in Mr. Cockle's collection.

\section{RHYNCHAGROTIS COSTATA Grote.}

Seventy specimens, July 25, 30, 31, August 3, 4, 5, 6, 7, 11, 13, 15, 16, 17, 21 (Revelstoke). Very variable, from dark purple brown to light ocherous clay color. This species has been named costata Grote and confusa Smith in Mr. Cockle's collection, but after attempting to separate two species in my series, I am convinced that it can not be done. Costata has the collar broadly tipped with black and confusa not so, according to Prof. J. B. Smith's published articles, and these two forms are present in my material, but they insensibly intergrade. The dark specimens have the black tip to the collar, the pale ones lack it, while intermediate ones have a purple brown tip, which can be interpreted either way. The slight differences in the male genitalia, as shown by Smith, ${ }^{a}$ are apparently not of specific value.

\section{ADELPHAGROTIS INDETERMINATA Walker.}

Three hundred and fifty-nine specimens, July 27, 30, 31, August 1, $3,4,5,6,7,12,13,15,16,17,21$ (Revelstoke), September 1 (Vancouver Island). A very constant and easily recognizable species, most 
inappropriately named. Like many others of the Agrotids, it appeared so late in the season that we made no attempt to obtain the larvæ. Hampson refers the species to the genus Eurois.

\section{ADELPHAGROTIS PRASINA Fabricius.}

One hundred and twenty-eight specimens, July 2, 8, 14, 19, 21, 25, 27, 30, 31, August 1, 3, 6, 7, 13, 17, 18, 22 (Revelstoke).

Egg.-Laid in a high pile, several layers thick in the center; neatly two-thirds spherical, base flat; ribs about 50, thin, narrow and very regular, not diminishing in number till near the summit, and then very inconspicuously. They are joined by neat, distinct cross striæ, forming square cells. Above them are two rows of cells, one rounded quadrangular, the upper ones neatly trapezoidal; the micropylar crown radiately, finely but slightly raised, not showing a distinct cell structure; greenish white, later with apical, vacuolar reddish spot, no ring; diameter, $0.7 \mathrm{~mm}$.

Stage 1.-Head bilobed, shining black, epistoma reddish. Cervical shield trapezoidal, shining black; body moderate, semilooping; feet of joints 7 to 8 shorter than the others; all whitish, immaculate; thoracic feet faintly infuscated; abdominal ones white. Joint 12 slightly enlarged; tubercles very small and inconspicuous, black; setæ rather long, dark, pointed; skin shining.

Stage II.-Head translucent pale luteous, slightly spotted by the tubercles; width, $0.65 \mathrm{~mm}$. Body rather slender, joint 12 slightly enlarged, the feet of joints 7 and 8 small; soft translucent green, the food darker; dorsal, subdorsal, and broad substigmatal lines a shade paler; tubercles small, black; feet pale; no shields.

Stage III.-Head round, slightly bilobed, the apex in joint 2, luteous, shining; the tubercle spots black; width, $0.9 \mathrm{~mm}$. Body moderate, joints 5, 6, and 12 slightly enlarged, feet of joint 7 small; green, a little grayish, the segmental incisures folded, whitish. Dorsal line a series of white intersegmental dashes, subdorsal line dotted, no lateral line, but a dark olivaceous shade above the stigmatal band, which is broad, greenish white, and centrally greenish filled. Tubercles round black; feet pale; setæ fine, moderate; no shields. Joint 2 is pale in front.

Stage IV.-Head pale luteous; the tubercle spots black; width, 1.2 mm. Body moderate, joint 12 little enlarged; soft green, dorsal and subdorsal lines white, broken, edged by dark-brown dottings, forming traces of a lattice marking. Heavy dark marking above the white stigmatal line, which is partly green-filled. Tubercles in dusky spots; feet pale.

Stage V.-Head pale brown with dark reticulations, a broad shaded band on the lobe before, tubercles black; width, $1.7 \mathrm{~mm}$. Body moderate, joint 12 enlarged dorsally and laterally; pale olivaceous, brown- 
ish tinted, dorsal line broken into dashes, subdorsal into dots, white; black oblique shades, dotted, forming obscure, cuneiform, subdorsal patches; irregular shades in lateral space edging the substigmatal line above; this line scarcely white, a little lighter than the subventral color, a slight black marbling at its lower edge, not continuous. Tubercle i black; cervical shield black marbled, with dorsal and subdorsal pale lines.

Stage VI (head, $2.7 \mathrm{~mm}$.) and Stage VII (head, $3 \mathrm{~mm}$.).-Head rounded, bilobed, pale brown, with dark recticulations and shaded brown band, shining. Body pale olivaceous, shaded with black; dorsal line bright white, linear, broken in the incisures; subdorsal of small specks only, all heavily black marbled to the substigmatal line, which is white above, olivaceous and black filled, the subventral region less heavily black. Feet green; a transverse white line on joint 12, black before; no dorsal line on joint 13. Cervical shield more brownish, lined; cuneiform marks obsolete, lost in the general shading.

The larvæ hibernated without being fully grown, though probably in the last stage.

\section{ADELPHAGROTIS APPOSITA Grote.}

Fifty-eight specimens, July 19, 20, 25, 30, 31, August 3, 4, 5, 6, 7, $11,12,15,16,17$, and one from Mr. Cockle's collection July 18. Rather variable. The dark forms have the markings picked out by rows of fine white scales, the ordinary lines nearly lost. Eggs were secured from two captive females, but they proved sterile.

Eggs.--Laid loose, rolling about. Nearly spheroidal, a slight flattening at the vertex and base. Ribs distinct, sharp, with rounded hollows between, about 36 on a side, diminishing above by confluence. Reticulations fine, obscure, forming square cells. The ribs become small at the vertex and are joined by striæ nearly equal to them, but run practically to the micropylar rosette, which is scarcely raised: pale yellow; diameter, $0.7 \mathrm{~mm}$.

\section{PLATAGROTIS PRESSA Grote.}

Eleven specimens, July 15, August 5, 6, 7. Placed by Hampson in the genus Aplectoides Butler.

\section{ABAGROTIS ERRATICA Smith.}

Eight hundred and twenty-one specimens, July 24, 27, 30, August $1,3,5,6,7,15,17,18$. It varies from dark stone gray to pale clay color. Specimens of the light form have been named ornatus by Prof. J. B. Smith. Mr. Cockle has a cotype of this variation in his collection.

PACHNOBIA SALICARUM Walker.

No specimens; one in Mr. Cockle's collection. 
SETAGROTIS VERNILIS Grote.

Twenty-eight specimens, July 2, 27, 30, August 3, 5, 6, 11, 12, 13, 17, 18. Uniform and of a darker, bluer gray than specimens from the Sierra Nevada of California or from Vancouver Island. There is no tendency to the pinkish or ocherous tints. The orbicular is oblique, elongate, sometimes very much so, and confluent with the lower angle of the reniform.

\section{SETAGROTIS VOCALIS Grote.}

Five specimens, July 10, 24, August 5, 9. Smith erected the genus Setagrotis on two species, planifrons and congrua, defined by having the antennæ with tufts of hairs instead of ciliate or simple. The character is a weak one, but such as it is is exhibited equally by vocalis Grote, placed in Noctua by Smith. The species planifrons and congrua are only variations of one form and both synonymous with vocalis. The Kaslo specimens, while too few to properly exhibit the species, show a good range of variation, the black tip to the collar and basal dash of fore wings being present or absent. The tone of the wings is very dark gray, darker than any other specimens before me. This is the general tendency in the Kaslo moths, but it may be due in part to the freshness of the specimens and may not be so noticeable after they have been in the collection a few years.

\section{AGROTIS YPSILON Rottemburg.}

Five specimens, August 1, 5, 6, 7 .

\section{PERIDROMA OCCULTA Linnæus.}

Seven hundred and forty-seven specimens, July 21, 25, August 1, 3, 6, 7, 15, 16, 18, 20 (West Robson), 21 (Revelstoke). Eggs were obtained from captive moths and the larvæ all hibernated. A few were, however, forced to the last stage, so I am able to give the full life history. Six stages, the normal number, are here described, though most of the larvæ interpolated a stage between the third and fourth and between the fourth and fifth, caused by the tendency they have to remain small till the winter is passed.

Eggs.-Laid in a high pile several layers deep centrally. Two-thirds spherical, spheroidally flattened, base flat; ribs about 26, diminishing above, narrow, not markedly raised, joined by cross-striæ about as distinct as themselves which form cells twice as wide as high, rounded, the cell areas concave and indenting the ribs. Vertex finely reticulate about the micropylar rosette, which is slightly raised. Pale yellow; diameter, $0.7 \mathrm{~mm}$.

Stage I.-Head bilobed, pale brown, black spots on the tubercles and small mottlings on the lobes above. Body normal, joint 12 slightly 
enlarged, feet of joints 7 and 8 smaller than the others; shield, tubercles, and leg plates very weakly infuscated. Tubercles rather large; setæ black, pointed.

Stage II.-Head shining brownish luteous; width, $0.6 \mathrm{~mm}$. Body rather elongate, thorax slightly tapered, joint 12 scarcely enlarged. Green, shaded with vinous brown to the middle of the subventral area. Dorsal, subdorsal, and broken lateral lines whitish; substigmatal line broad, pure white. Tubercles minute, dark, setæ small.

Stage III.-Head bilobed, pale brownish, tubercles and vertical line blackish; width, $0.8 \mathrm{~mm}$. Body rather flattened, moderate, dorsum luteous, dorsal and subdorsal lines white, dark edged, lateral area dark, vinous tinted, a shadow in place of the lateral line; substigmatal band broad, pure white; subventral area like the dorsum, but retracted. Feet very pale; those of joints 7 and 8 small; no shields; tubercles black, setæ minute.

Stage IV.-Head bilobed, rounded, pale brown, reticulations and distinct vertical band dark brown; width, $1.4 \mathrm{~mm}$. Body moderate, joint 12 enlarged, without shields. Dorsum broadly carneous pinkish, dorsal and subdorsal lines whitish, broken intersegmentally, the subdorsal narrower and subobsolete, darker edged; scattered dark specks in the dorsal space; a distinct, black, cuneiform subdorsal mark on joint 12 forms a transverse bar. Lateral space black, inclosing the subdorsal line, scarcely pale dotted; substigmatal line white, pale carneous filled centrally; subventer pinkish, black irrorate; feet pale, black dotted. Tubercles black, not contrasted; setæ pale, moderate.

Stage V.-Head light pinkish in ground; heavily reticulate in brown black and with broad vertical bands; width, $2.5 \mathrm{~mm}$. Dorsum lilaceous with diffuse oblique shades of black linings defining the concolorous dorsal line and forming black cuneiform patches on joints 11 and 12, that on 12 large and forming a single patch. Subdorsal line nearly concolorous with ground, segmentally lightened in orange; sides wholly black penciled; substigmatal band lilaceous with a rather broad, pale yellow, bright upper edge and salmon pink below, reaching from joint 2 to the anal foot. Substigmatal band below black penciled, its lower edge free of black. Subventral region of the same color, powdery black marked; abdominal feet concolorous, thoracic ones brown.

Stage VI. - Head shining violaceous, heavily reticulate in black with broad curved vertical bands each side of the clypeus and erect streaks from and behind the eye; clypeus black shaded; antennæ long, the basal joint whitish, second black at base, third reddish; width, $3.3 \mathrm{~mm}$. Body moderately robust, equal, no enlargements, joint 13 roundedly smaller. Dorsum velvety black, very slightly vacuolated with lilaceous, dorsal line obsolete; a white speck at tubercle i. Cervical shield with a distinct dorsal reddish violaceous line and broken subdorsal one, 
else black. Anal flap with three similar lines. A bright white and lilaceous speckled transverse bar on joint 12. Subdorsal line lilaceous and white dotted, broken into slightly oblique segmentary bars, shaded. Sides lighter than dorsum, black penciled on a whitish lilaceous ground, solidly black below. A narrow, crinkled, pale yellow stigmatal line representing the upper edge of the substigmatal band, the space below like the lateral area, black on lilaceous. Thoracic feet reddish, abdominal ones heavily black marked, the anal pair yellow lined before. Tubercles small, obscure; setæ moderate, pale, straight.

PERIDROMA ASTRICTA Morrison, var. SUBJUGATA Dyar.

Sixty-one specimens, July 19, 25, 27, 29 (Bear Lake), 30, 31, August $3,5,6,11,13,16,17$. This is obviously a local form of the eastern astricta, yet it comes remarkably near to nigra Smith in appearance. It retains always some of the violaceous ground color of astricta, which, in nigra, is transformed into an ochraceous powdering.

Eggs.-Laid in a high pile three or four layers deep centrally. Twothirds spherical, the base more or less flattened, somewhat irregular. Ribs about 40 around the margin, diminishing by confluence, running almost to the raised micropylar rosette. Cross-striæ fine, slight, forming cells about twice as wide as high. Light y ellow, later with a dark red ring and spot; diameter $1 \mathrm{~mm}$.

Stage I.-Head rounded bilobed, brown, clypeal sutures and tubercular spots blackish. Body normal, whitish, joints 5-6 and 12 enlarged; cervical shield bisected, blackish at the edges and tubercles. Tubercles round, black, distinct; thoracic feet blackish ringed; leg shields dusky; setæ black, pointed. I ater green from the food, a whitish stigmatal stripe edged with dark above and a little brown also subdorsally and subventrally.

Stage II.-Head bilobed, shining greenish brown with obscure spots on the tubercles; width $0.6 \mathrm{~mm}$. Body moderate, joint 12 scarcely enlarged; greenish, shaded in brown, dorsal line opaque dull white, divided in the incisures and a little constricted centrally on the segments; subdorsal line narrow; lateral line a row of dull white spots. Below it a heavy dark vinous shade. Substigmatal band pure white; subventral region greenish, like the dorsum. Tubercles small, round, black; feet pale; cervical shield concolorous, but defined by a dark line.

Stage III.-Head brown, slightly reticulated; width $0.8 \mathrm{~mm}$. Body moderate, joint 12 enlarged; light fleshy brown dorsally with dorsal and subdorsal white lines, slightly dark brown edged, forming traces of a lattice marking with lighter areas about tubercle i. Sides dark brown; lateral line obsolete; substigmatal band pure white; subventral region pale brown, fading to the venter. Feet brownish; no shields; tubercles small, round, black; setæ minute.

Stage IV.-Head rounded bilobed, shining light brown with darker 
reticulations and nearly straight vertical bands; width, $1.1 \mathrm{~mm}$. Body moderate, without shields, joint 12 well enlarged. Dorsum of joints 3 to 13 violaceous pink, the white dorsal and subdorsal lines black edged and with faint oblique black shades forming cuneiform dashes on joints 11 and 12, especially on 12 . Joints 2, 13, and the sides heavily mottled in black; substigmatal band pure white, narrowly pinkish filled. Feet pale with smoky shades; tubercles black, indistinct; setæ obscure. Anal flap diluted paler.

Stage V.-Head shining whitish luteous with distinct reticulations and broad vertical bands of smoky brown; width $2.2 \mathrm{~mm}$. Joints 2, 13 and anal feet mouse brown with three white lines. Body moderate, joint 12 well enlarged. Dorsum carneous violaceous with black cuneiform subdorsal marks on joints 3 to 12, largest on joint 12, squarely cut behind. Dorsal and subdorsal lines white, yellow tinted, black edged intersegmentally; tubercles $\mathrm{i}$ and ii white. Sides above violaceous, heavily black mottled, below solidly black. Substigmatal band yellow, white at the borders, violaceous carneous filled. Feet pale carneous.

Stage VI.-Head rounded, shining pinkish brown, clypeus unspotted, vertical bands each side of it curved, broad, black, the sides reticulate and with a slight narrow band from ocelli; width, $3.4 \mathrm{~mm}$. Body moderate, joint 12 scarcely enlarged; cervical shield and anal plate large, bright red brown, contrasted, the cervical shield darker shaded before and with three faint yellowish lines, anal plate with subdorsal line. Body dark lilaceous brown, nearly uniformly black penciled, forming a series of oblique subcuneiform subdorsal bars, faint on the thorax, ending at joint 12 with a transverse white line. A stigmatal black line, broken segmentarily. Dorsal line narrow, white, obsolete centrally on the segments, faintly dark edged; subdorsal line broader, yellow, distinct, interrupted intersegmentally and tending to follow the oblique subdorsal black bars, faint on the thorax, ending on joint 12. Substigmatal band with yellow and white upper edge, dark pink filled below; subventral space dull lilaceous. Feet pale, thoracic ones brown. Tubercles and setæ obscure.

\section{PERIDROMA NIGRA Smith.}

Thirteen specimens, July 30, August 5, 6, 7, 11, 12, 15, 17 .

PERIDROMA MARGARITOSA Haworth.

Fifteen specimens, June 2, 4, 11, 13, 16, 25, 30, July 8, August 7, 11, 17. The species was rare, but Mr. Cockle says it was a perfect pest the year previous, and thousands of egg masses could be seen. He attributes the scarcity of the species in 1903 to the destruction of the hatching larvæ by early rains. Eggs were obtained and a brood of the larvæ raised, exhibiting the usual well-known characters. 
NOCTUA BAJA Linnæus.

Six hundred and fourteen specimens, July 27, 30, August 2, 5, 6, $7,13,16,17,18$. This is unquestionably the European species. It was long so recognized till in $1896 \mathrm{Mr}$. P. T. C. Snellen named the American form smithii, on the supposition that it had spinose fore tibiæ while the European one had not. But an examination of European specimens shows them to have several distinct spines toward the tip of the member, well hidden in the vestiture. I therefore restore the old name. The specimens before me vary from red brown to gray.

NOCTUA PLEBEIA Smith.

Twenty-eight specimens, July 19, 27, August 4, 6, 7, 11, 15. The form is not very variable, and seems to be a distinct species.

\section{NOCTUA ROSARIA Grote.}

Ninety-two specimens, May 29, June 7, 11, 23, 30, July 19, 21, 26, 27, 29, 31 (bred), August 1 (bred), 4 (bred), 7, 11, 13. I have attempted to arrange these specimens in two series corresponding to rosaria and esurialis, but they insensibly intergrade. I can not see that Professor Smith demonstrates any difference between the male genitalia ${ }^{a}$ beyond what is accounted for in difference of drawing and natural variation. On examining several specimens I see enough variation to account for the "much narrower harpes" of esurialis which Professor Smith notes.

Egg.-Two-thirds spherical, base flattened; ribs about 25, raised, moderately broad at summit, the spaces concave; cross-striæ fine, not raised, micropyle reticulate; pale yellow; diameter, $0.9 \mathrm{~mm}$.

Stage I.-Head broad, bilobed, black, clypeus high, width, $0.3 \mathrm{~mm}$. Body short, robust, normal, joint 12 enlarged, feet of joints 7 and 8 short. Translucent whitish, unmarked, reddish from the alimentary canal, cervical shield and thoracic feet blackish. Tubercles small, blackish, with long, pale, granular bulbous-tipped setæ, iv below the center of the spiracle; no leg shields; spiracles black rimmed.

Stage II.-Head round, shining transparent colorless, sordid on vertex; width, $0.5 \mathrm{~mm}$. Body normal, feet of joints 7 and 8 small; whitish smoky shaded, especially along tubercules iii, defining a straight white dorsal line and traces of a wavy subdorsal one. Shields concolorous, tubercles rather large, blackish, setæ short.

Stage III.-Head rounded, shining sordid luteous, tubercles dark, a smoky violaceous, broad, curved band each side of clypeus and suture; width, $0.8 \mathrm{~mm}$. Body normal, equal, feet of joints 7 and 8 short, 12 slightly enlarged dorsally. Dorsum violaceous brown, cervical shield luteous, sides darker brown, venter again pale. Dorsal

a Jour. N. Y. Ent. Soc., VI, 1898, pl. vir, figs. 7, 8, and 9.

Proc. N. M. vol. xxvii-03-57 
and subdorsal lines narrow, pure white, dark brown edged, segmentarily narrowly broken. Substigmatal band white, filled with the ground color except at the edges. Tubercules small, round, black; setæ short; feet all pale sordid; shields not cornified.

Stage IV.-Head rounded, broad, slightly bilobed, shining pale luteous, scarcely mottled; width, $1.3 \mathrm{~mm}$. Body robust, normal, joint 12 hardly enlarged, feet equal. Dorsal line white, narrow, pulverulent, dark brown edged; subdorsal space reddish flesh color, mottled, containing white tubercles $\mathrm{i}$ and ii with black hair dots. Lateral space dark brown, mottled, just inclosing above the narrow, broken, white subdorsal line. Substigmatal band broad, flesh color, with light white narrow edges; subventral space flesh color, mottled in brown and white. Feet all pale.

Stage $V$.-Head rounded, shining, pale, a heavy brown-black band each side of clypeus, vacuolated above; a band in clypeus; sides heavily reticulate; width, $2 \mathrm{~mm}$. Body robust, even, joint 12 not enlarged, 13 truncate obliquely. Dorsum broadly pale, dotted in brown, especially centrally, where a heavy shade borders the subobsolete white dorsal line. Sides below tubercle ii deep velvety brown with a string of white powdering for the subdorsal line and a narrow lateral dilution. Substigmatal band broad, white on the edges, dark red-brown filled. Thoracic feet smoky, abdominal ones pale; tubercles white with black hair dots and short setæ; shields uncornified, concolorous.

Stage VI. - Head rounded, the apex slightly in joint 2, shining, pale ground overlaid with dark brown reticulations, vertical band very broad, black, whitish edged posteriorly; width, $2.6 \mathrm{~mm}$. Body normal, feet equal, joint 12 slightly enlarged. Dorsum ocherous brown, dotted, reticulate, centered by a dark brown shade cut by white linear dashes, the remains of the dorsal line. Tubercles $\mathrm{i}$ and ii whitish with black hair dots. Sides dark velvety brown, reticulate, darkest subdorsally and stigmatally, cut very obscurely by the remains of the subdorsal line. Substigmatal band with white edges, filled with dark brown, like that of the subventral region, reticulate, whitish dotted; a subventral dilution. Thoracic feet brown, abdominal ones pale; spiracles yellowish white, black ringed; no shields.

Eggs, June 12; larvæ pupated, July 18; first moth, July 31.

NOCTUA CYNICA Smith, var. PERUMBROSA Dyar.

One hundred and seventeen specimens, July 21, 25, 27, August 5, 6, 7, 11. This is like the Eastern rubifera Grote and cynica Smith, but darker in color. Whether there are two species mixed, differing only in genitalia, as Smith claims to be the case with the Eastern forms, I do not know, as all those examined agreed with the figure of cynica. Some of the specimens run close to the obscure form of rosaria. We did not obtain the larva on account of the lateness of appearance of the moths. 


\section{NOCTUA OBLATA Morrison.}

Sixty-six specimens, June 25, July 19, 24, August 4, 5, 7, 11, 12, 13 , 17. The species is apparently double brooded. I could not obtain larvæ of the first brood, and those of the second hibernated before reaching maturity, so I am able to present only a partial life history. Stage vi remains to be described.

Egg.-Laid in a large patch. Two-thirds spherical, base well flattened, a little obliquely irregular. Ribs about 25, large, coarse, deeply cut, crowned by the vertical reticulations, the cross-striæ distinct and forming rectangular cells over twice as wide as high. Vertex quadrangularly reticulate around the elevated micropylar rosette. Waxy white, no change till hatching; diameter, $0.9 \mathrm{~mm}$.

Stage I.-Head bilobed, brownish luteous. Body normal, joint 12 a little enlarged, feet of joints 7 and 8 small; whitish, cervical shield sordid with black spots. Tubercles round, black, distinct; feet pale; shields blackish.

Stage II. - Head bilobed, shining light brown with a few dark dots; width $0.5 \mathrm{~mm}$. Body with joints 5-6 and 12 slightly enlarged, sordid pale in ground, heavily shaded with dark brown of the color of dead leaves. Dorsal and subdorsal lines white, broken, less distinct at the ends. Below spiracles sharply paler, no defined lines. Feet sordid; tubercles rather large, black; shields concolorous.

Stage III.-Head bilobed, the apex in joint 2, shining luteous, tubercles and front irregularly marked in brown, faint reticulations on the lobes; width $0.85 \mathrm{~mm}$. Body moderate, a little smaller before, joint 12 enlarged, feet nearly equal. Pale brown washed with darker, forming dorsal oblique streaks from dorsal posterior to subdorsal anterior and covering nearly all the sides. Dorsal line pale, subdorsal white dotted, stigmatal broad, pale, its narrow edges nearly white; subventral area pale. Tubercles round, black; no shields; setæ fine, obscure; feet pale.

Stage $I V$.-Head as before, luteous below, brown on the vertex, tubercles dark; width, $1.1 \mathrm{~mm}$. Dorsum pale brown, dark marbled, with a deep brown broken lattice. Dorsal and subdorsal lines dotted white, dark edged. Sides very dark, hardly a trace of lines, the substigmatal white edged, its filling like the subventral area, pale brownish. Feet pale; tubercles black; shields absent. An interpolated stage occurred in several of the larvæ between this and the next, with width of head of $1.4 \mathrm{~mm}$.

Stage V.-Head rounded bilobed, shining pale brown with dark brown bands and reticulations; width, $2.1 \mathrm{~mm}$. Body pale carneous brown, cervical shield concolorous, but with black points in a Vshaped row, a dorsal white line and subdorsal spot anteriorly. Dorsal dark lattice faint and broken, showing intersegmentally as geminate 
shades edging a broken white dorsal line; a narrow transverse bar on joint 12. Sides dark, enveloping the pale subdorsal line; subventral region light brown like the dorsum, the edges of the substigmatal band showing yellowish, the filling rather reddish brown. Thoracic feet brown blackish; tubercles and spiracles black, not conspicuous. The dorsal line shows white anteriorly.

Stage VI.-(Not observed.)

NOCTUA C-NIGRUM Linnæus.

Thirty-four specimens, July 21, August 1, 3, 5, 7, 11, 16, 17, 18. We did not attempt to breed this well-known species.

NOCTUA FENNICA Tauscher.

One specimen, August 7.

NOCTUA PLECTA Linnæus.

One specimen, June 20.

NOCTUA UNICOLOR Walker.

Two specimens, June 30, July 8.

NOCTUA SIERRA Harvey.

Three hundred and eighty-nine specimens, June 23, 25, July 8, 14, 19, 25, 29 (Bear Lake), 31, August 1, 2, 5, 7, 11, 17. This is probably not more than a local race of haruspica Grote. It is darker and the hind wings are a little more silky grayish. It may not be distinct from inopinatus Smith, which name it bears in Mr. Cockle's collection. Smith's types came from different faunal regions. The "inopinatus" from Corfield, Vancouver, are probably normal sierræ, and I would prefer to reserve the name inopinatus for the smaller form inhabiting the high prairies, typified by the Winnipeg, Manitoba, specimens. Eggs were obtained from captive females, but the larvæ hibernated, and only the most active ones were forced to stage $\mathrm{v}$ in September, so that the last stage remains to be described.

Egg.-Three-fourths spherical, rather high, the sides straightened, base flattened narrowly, vertex smooth. About 35 ribs, diminishing to 11 at the vertex, low, broad, but with linear crests and fine distinct cross-striæ, forming rectangular cells wider than high. Vertical reticulations elongate radially. Pale greenish white, no change before hatching; diameter, $0.9 \mathrm{~mm}$.

Stage I.-Head rounded bilobed, blackish brown. Body moderate, normal, joint 12 enlarged, feet of joints 7 and 8 small. Whitish colorless, tubercles large, smoky black, cervical shield and bases of the feet similar, the tips clear; no leg plates. Setæ long, brown, pointed; skin sparsely dark granular. 
Stage II.-Head shining brown, darkly shaded above and in clypeal sutures; width, $0.5 \mathrm{~mm}$. Cervical shield dark brown; body moderate, equal, dark green dorsally, pale subventrally; dorsal line white, divided into two round spots to each segment; subdorsal dotted, lateral a trace; stigmatal band faint, indicating the boundary between the dorsal and ventral shades of green. Tubercles large, round, black; feet pale.

Stage III.-Head dark shining brown, slightly reticulated, mouth pale; width, $0.8 \mathrm{~mm}$. Body moderate, dorsum dark brown, subventer pale vinous tinted. Dorsal line white, segmentarily subbimaculate; subdorsal dotted, stigmatal narrow, white, dividing the dorsal and ventral colors. Tubercles $\mathrm{v}$ and vi black blotched. Thoracic feet and leg plates black. Tubercles obscure; setæ pale.

Stage IV.-Head rounded, shining brown with black reticulations and bands; width, $1.2 \mathrm{~mm}$. Body with joint 12 slightly enlarged, dark brown, shaded solidly along the sides. Dorsum and subventer pinkish brown; dorsal and subdorsal lines dotted only, mixed with other white dots. Upper edge of the stigmatal band white, the rest like the subventral area. A cuneiform brown subdorsal patch on joint 12. Tubercles small, black, partly white ringed; thoracic feet brown, abdominal ones pale.

Stage V.-Head rather high, rounded, the apex in joint 2, shining light pinkish brown with broad black band from base of clypeus to apex of lobe, joined by fine black reticulations, a patch before ocelli and narrow band behind; width $2.2 \mathrm{~mm}$. Body moderate, normal, joint 12 scarcely enlarged. Olivaceous gray, finely black peppered and penciled on an olivaceous lilaceous ground. Dorsal line a faint pale streak, widened into a pale yellow spot posteriorly on the segments; subdorsal line a row of small yellow dots, with one at tubercle ii and anteriorly on the segment just above it; dorsal space evenly peppered, a little darker intersegmentally on the dorsal line; the subdorsal cuneiform black spot on joint 12 forms a narrow velvety bar, constricted centrally, but not divided. Subdorsal line continuous on joints 12 and 13, pale yellow; on the anterior edge of the cervical shield carneous tinged. Sides evenly peppered, violaceous washed below; substigmatal line moderate, even, its upper edge forming a narrow pale yellow line, waved, black-edged above, its lower edge fainter but similar, filled with brownish dots like the subventral area, a little more reddish than that, and both on a violaceous ground. Thoracic feet light brown, abdominal pale; venter whitish; tubercles obscure; setæ moderate.

Stage VI.-(Not observed.) 


\section{PRONOCTUA PYROPHILOIDES Harvey.}

One specimen, July 25, and one from Mr. Cockle's collection, referable to the Californian form pyrophitoides. A large pinkish wellmarked form occurs in Colorado (typica Smith) and a smaller pinkish lightly marked form in southern Utah (peabodyæ Dyar).

\section{CHURIZAGROTIS AUXILLARIS Grote.}

One specimen, September 8 (Glacier).

CHORIZAGROTIS AGRESTIS Grote.

Two specimens, August 9 (Kokanee Mountain, Mr. W. R. Allen), 10 (Kokanee Mountain, on the Glacier). This, with the preceding, which are doubtlessly only forms of one species, would seem to be wanderers from another faunal region. The species is very common throughout the plains and in the foothills of the Rocky Mountains to the south, and it is to be noted that they were only taken in the Kootenai district at high altitudes, or trapped on snow, probably while migrating.

\section{RHIZAGROTIS FLAVICOLLIS Smith.}

Five specimens, July 18, August 1, 3, 4, 5. This species has the appearance of a Paragrotis of the flavidens group, but the antennæ of the male are bristled and ciliate only, not serrate. Smith defines Rhizagrotis from Paragrotis in that the former has the male antennæ "simple or ciliate only," the latter " pectinate or serrate and bristled." While flavicollis does not conform exactly with either, it is probably best referred to Rhizagrotis, from the absence of the serrations.

FELTIA SUBGOTHICA Haworth (JACULIFERA Guenée).

One specimen, August 13.

FELTIA HERILIS Grote.

One hundred and sixty-three specimens, July 14, 19, 25, 30, August 3, 6, 17, 18, 20 (West Robson). They vary but little. After seeing this excellent series I am convinced that this is a distinct species, not a variety, as given in Bulletin No. 52, U. S. National Museum. The nomenclature there adopted may be amended so as to recognize three species. $^{a}$ In Bulletin No. 38, U. S. Mational Museum there is an error in the synoptic table on page 111. It should be herilis which has the short branches to male antennæ, not tricosa (jaculifera of the table) as there given. The life history was observed.

$a$ See also Grote, Can. Ent., XXXV, 1903, p. 258, and Hampson, Cat. Lep. Phal. Brit. Mus., IV, 1903, pp. 343-346. 
FELTIA VANCOUVERENSIS Grote.

Seventy-five specimens, May 31, June 5, 13, 16, 25, July 2, 28 (Bear Lake Mountain). Somewhat variable in color and the distinctness of the markings. Eggs were freely laid by captive females.

Egg.-Laid singly, adherent, pressed under objects in the jar. Nearly spherical, the basal half spheroidally flattened. Ribs about 40, low, not short, diminishing toward vertex. Reticulations all over surface, forming crests to the ribs and cross-striæ between, moderate, not sharp; all granular shagreened; area about the micropyle reticular, the micropyle itself a raised cone with circle of pyriform cells. Pale yellow, later with a broken red ring and spot; diameter $0.9 \mathrm{~mm}$.

Stage I.-Head rounded bilobed, wider than high, clypeus high; black, epistoma and antennæ whitish. Body colorless whitish, green from the food, shields and tubercles blackish. Cervical shield moderate with two detached setæ; tubercles not large, setæ pale with bulbous tips, iv above the center of spiracle. Thoracic feet blackish.

Stage II.-Head rounded bilobed, shining black; width, $0.4 \mathrm{~mm}$. Body robust, cylindrical, joint 12 not preceptibly enlarged. Sordid greenish white with faint marks of brown, washed longitudinally. Cervical shield and plates shining black; feet of joints 7 and 8 small. Tubereles round, black; setæ short, distinct. Thoracic feet dusky.

Stage III.-Head rounded quadrate, shining black, sutures pale; width $0.6 \mathrm{~mm}$. Body sordid brown, the green showing a little, dorsal, subdorsal, and lateral lines fine, whitish, obscure; substigmatal line broad, pale; subventer more greenish. Cervical shield large, semicircular; tubercles moderate; anal plate and leg shields shining black. Feet of joints 7 and 8 still small.

Stage IV.-Head rounded, broad, brown below, the vertex black, black dots on face and a patch on eye; width $0.8 \mathrm{~mm}$. Body dark sordid brown, the ordinary lines showing a shade paler, dark edged. Tubercles rather large, brown black; shields smoky; setæ short, pale, slightly enlarged at the tips.

Stage V.-Head round, solidly brown black over lobes, clypeus and area about eyes pale, sordid; width $1.2 \mathrm{~mm}$. Body moderate, uniform, joint 12 scarcely enlarged. Dark sordid brown, a pale subdorsal band, contracted at the incisures indicates a broad pale dorsal area, nearly filled with dark brown; dorsal line pale, obsolete. Sides dark, the stigmatal region paler, lateral line obsolete. Tubercles rather large, round, black; cervical shield large, shining brown black; setæ short.

Stage VI.-Head as before, width, $1.7 \mathrm{~mm}$. Joint 12 scarcely enlarged. The pale dorsal space is now distinct with central diamondshaped marks. Sides dark, lateral line indicated. No other distinct 
markings. Cervical shield large, dark with pale bisecting line. The spiracle and tubercle iv together show as a black spot.

Stage VII.-Head $2.8 \mathrm{~mm}$. Cervical shield shining black with pale dorsal and subdorsal lines. Dorsal space pale with faint diamondshaped marks. Sides nearly black, lighter streaked above and on subventral fold. Tubercles large, black, shining. Head brown, reticulate in black with the usual vertical bands.

\section{FELTIA VOLUBILIS Grote.}

One specimen, June 19. This seems to me only an extreme form of vancowverensis.

\section{FELTIA ÆNEIPENNIS Grote.}

Three specimens, June 16, 23, July 2, which I refer with some doubt to this species. They are not of the faded brown which is usual, but the colors are darker and more contrasted. On the other hand they are smoother than vancouverensis and less contrastingly marked.

Egg. - Spheroidal, the base narrowly flat. Ribs about 40, diminishing by alternation at upper third, crowned and separated by the vertical reticulations, which with the cross-striæ form nearly square cells, rather faint, not raised. The ribs bend at the edge of vertex and become smaller, but run right to the micropyler elevation with its circle of pyriform cells. Pale yellow; diameter, $0.8 \mathrm{~mm}$.

Stage I.-Head round, bilobed, shining black; cervical shield black. Body robust, short, joint 12 not enlarged, feet of joints 7 and 8 short. Tubercles round, black, normal, elevated, setæ long, pale at tips, with enlarged glandular ends. Body sordid whitish, unmarked.

Stage II.-Head bilobed, the lobes blackish, sutures and clypeus pale; width, $0.45 \mathrm{~mm}$. Cervical shield semicircular, black, as also the anal plate, tubercles, and thoracic feet. Body robust, short, joint 12 not enlarged, pale green, no marks; abdominal feet pale. The larva is sluggish and fat, a little narrowed at the ends.

Stage III.-Head full, sordid whitish, the apices of the lobes smoky; tubercles dark; width, $0.6 \mathrm{~mm}$. Body short, robust, a little flattened, pale, shaded with brown, leaving dorsal subdorsal, lateral, and broad stigmatal bands of the ground color, brown edged. Cervical shield smoky, trilineate in pale. Tubercles rather large, blackish, slightly elevated; setæ pale, minutely bulbous tipped; feet of joints 7 and 8 still short.

Stage IV.-Head rounded, the apex in joint 2, pale brown, a large, dark brown mark on the face of each lobe; width, $1.1 \mathrm{~mm}$. Body robust, quadrangularly flattened, joint 12 gently enlarged. Sordid brown; dorsum broadly pale to tubercle ii, with faint indications of lattice unarking. Sides dark, inclosing very narrow, scarcely percep- 
tible, whitish subdorsal and lateral lines. Subventral area sharply paler, but sordid, not greatly contrasted. Tubercles large, black, shining; cervical shield black, a dorsal pale line and diffuse subdorsal one; leg plates pale; setæ fine.

Stage T.-Head half retracted in joint 2, dark brown, clypeus pale; width, $1.8 \mathrm{~mm}$. Body moderate, joint 12 slightly enlarged; dorsal space broadly pale, with dorsal geminate darker lines, scarcely any indication of the lattice, brown dotted. Sides dark, with obsolete subdorsal and lateral pale lines; subventral area pale, feet still paler. Cervical shield large, shining black, with faint paler dorsal and subdorsal lines. Tubercles round, black; setæ short, pale.

Stage VI.-Head rounded, the apex well within joint 2, light brown, with dark reticulations and vertical bands; width, $2.5 \mathrm{~mm}$. Cervical shield shining brown, diluted in spots and with three pale lines; width, $2.5 \mathrm{~mm}$. Body equal, joint 12 scarcely enlarged. Dorsum broadly pale flesh color, dotted; dorsal line pale with diffuse dark edging, sides dark dotted, subventer and venter pale; feet also pale. Tubercles large, black, round, radially grooved; setæ moderate, dusky.

\section{POROSAGROTIS CATENULA Grote.}

Eight hundred and sixty-six specimens, July 16, 25, 27, 31, August $4,6,7,13,15,17$. They run much darker than the form from Coiorado and southern California, but a few are almost as light, and I think a racial name not necessary. The color is stone gray in the majority. The transverse-posterior line is continuous, finely and strongly scalloped, with white points on the veins. The variation is thus all away from vetusta Walker (=muræmula Grote and Robinson), and I do not think it a form of that species.

\section{POROSAGROTIS THANATOLOGIA, new species.}

No specimens; one in Mr. Cockle's collection is a female without abdomen. The specimen is labeled Paragrotis reuda Strecker, but does not agree at all with Hampson's figure or Strecker's description. Moreover, the spines on the fore tibiæ are so stout that the species seems referable to Porosagrotis rather than to Paragrotis (Euxoa of Hampson and Smith).

Head, collar, and thorax uniformly dark mouse gray. Fore wings elongated, much as in Chorizagrotis, light gray basally and terminally, the whole median space blackish, discolorous. Basal half line geminate, black, broken; a black basal dash, dislocated and widened beyond basal line, reaches nearly to transverse-anterior line. Lines geminate, crenulate, not strongly defined, the pale filling forming a costal spot for each. Transverse anterior nearly straight, transverse posterior moderately arched over reniform. Orbicular circular, reniform upright, well concave without, pale and narrowly black ringed, the 
orbicular dusky filled, the reniform with concentric dusky line; claviform black outlined, dark filled. Subterminal line pale, dentate moderately, with black cuneiform dashes preceding it, especially at interspaces 2-4 and 5-7; a dusky subapical shade. Terminal space blackish like the median space; fringe brownish. Hind wings brownish with white fringe. Expanse, $40 \mathrm{~mm}$.

Type.-Cat. No. 7882, U. S. National Museum.

\section{PARAGROTIS MAIMES Smith.}

One specimen, September 9 (Field). The species much resembles Rhizagrotis Alavicollis Smith, but differs in the color of the thorax and in the generic character of having the male antennæ shortly serrate. My single specimen from Field agrees with one kindly sent me by Mr. F. H. Wolley Dod, from " Head of Pine Creek," near Calgary, Alberta. It should be noted that Mr. Dod's collection about Calgary may cover two faunal regions. Calgary itself is in the prairie, and shows such a fauna as would be expected, while the locality "Head of Pine Creek" must be in the foothills of the Rocky Mountains, judging by the species sent out with this label.

PARAGROTIS BROCHA Morrison.

Thirty-seven specimens, July 30, August 3, 4, 5, 6, 11, 12, 13, 15, 16,17 .

\section{PARAGROTIS PUNCTIGERA Walker.}

Eight hundred and eighty-eight specimens, July 19, 21, 25, 27, August 5, 6, 7, 12, 13, 17, and three from Mr. Cockle's collection, July 25, 1901, July 25, 1902, August 1, 1902. The mass of the specimens fall between pastoralis Grote and finis Smith. These are the extreme forms. The series, when once sorted out, looks homogeneous and uniform, though varying greatly in the amount of yellow powdering on the lines and spots. The black line on the collar comes out more or less distinctly, destroying the value of this character in separating species. The hind wings are dark brown in both sexes. I think loya Smith is a variation of this type and perhaps some others that now stand as good species. Mr. Cockle's specimens before me are undersized and with very little of the characteristic powdering, and, without this series, I should never think of referring them to punctigera. They come extremely near to the brown form of focinus mentioned below. A well-marked specimen in Mr. Cockle's collection has been named compressipennis Smith, but it does not appear to me to agree with the type of that form which is before me. A brownish specimen, also in Mr. Cockle's collection, has been named friabilis Grote [focinus Smith, was meant, probably], but it does not agree with Hampson's figure and description of that form, which is otherwise 
unknown to me. ${ }^{a}$ Eggs were obtained from captive females, but with difficulty, and they did not prosper. Many remain unhatched, and what larvæ appeared were weak and did not proceed far. ${ }^{b}$

Egg.-Spheroidal, symmetrical, base not more flattened than vertex; sculpturing obsolete. Under a lens the ribs are faintly shadowed, thick, diminishing above; but under 87 diameters' magnification they are evanescent, only faint, rounded reticulations showing over the surface. Micropylar rosette rather distinct. Pale ocherous; diameter, $0.8 \mathrm{~mm}$. Laid in groups, strongly adherent.

Stage I.-Head rounded, brown, eye black. Body whitish colorless, shields and tubercles concolorous, obscure; setæ moderate, pale. Feet of joints 7 and 8 a little shortened.

Stage II.-Head round, black; width, $0.5 \mathrm{~mm}$. Cervical shield blackish. Body moderate, equal, brown, the incisures lighter; dorsal, subdorsal, and lateral lines and a broad stigmatal one whitish; dorsal space reddish brown, the lines dark edged, the edging at tubercle ii giving a slight effect of subdorsal patches. Sides dark filled between the lines. Substigmatal line distinct, whitish, and succeeded by a dark subventral area. Tubercles and setæ dark, obscure.

\section{PARAGROTIS TRIFASCIATA Smith.}

One specimen, which I believe represents this species, described from a single female specimen from Mount Hood, Oregon. My specimen is a male, but agrees well with the description and a colored figure in the National Museum made by Professor Smith, except for being darker in tone.

\section{PARAGROTIS PEREXCELLENS Grote.}

No specimens; one in Mr. Cockle's collection, August 14, 1901, erroneously labeled ridingsiana Grote, is evidently a straggler from the coast region, where the species is common.

\section{PARAGROTIS FOCINUS Smith.}

One hundred and six specimens, July 19, 24, 25, August 5, 6, 11, 16, and two from Mr. Cockle's collection, July 1, of a uniformly brownish tone, which I refer here as extreme forms. A few of those in my series are like them. Another specimen from Mr. Cockle's collection has been named fuscigera Grote, but does not agree with a specimen before me determined by Grote in 1870.

$a$ Cat. Lep. Phal. Brit. Mus., IV, 1903, p. 249.

${ }^{b}$ As this is in press (April 9, 1904) the eggs have begun to hatch. 
PARAGROTIS TERRENUS Smith.

Six specimens, August 5, 6, 18, separated from the fulda series, agree with the type of terrenus. The hind wings are dark, and the differences between this and messoria are not clear to me. A specimen in Mr. Cockle's collection has been named neotelis Smith, but lacks the purplish tint of that form and is obviously wrongly identified.

\section{PARAGROTIS FULDA Smith.}

Thirty-five specimens, August 6, 12, 13 (Sandon, Mr. Currie), 16, 17, 21 (Revelstoke). Those with the markings most obsolete agree with the type of fulda Smith; the majority are marked distinctly like messoria (=territorialis Smith). I should refer this series to messoria, except that the hind wings are generally whitish where in messoria they are overspread with brown. A specimen in Mr. Cockle's collection is identified as tessellata Harris and another as balinitis Grote, but neither identification is correct when compared with the specimens in the U. S. National Museum.

PARAGROTIS RUBEFACTALIS Grote.

Three specimens, July 14, 27, August 17, and one from Mr. Cockle's collection. They are not very much alike, and the females are doubtfully referred here. The male agrees with specimens that $I$ have from Pullman, Washington, under this name.

PARAGROTIS INCALLIDA Smith.

Twenty-seven specimens, July 2, 29 (Bear Lake Mountain), 30, August 3, 4, 6, 7, 11, 12, 13 (Sandon, Mr. Currie), 15, 16, 17. Distinctly variable, running to a smooth, obscure form, with the maculation nearly lost. Before I was acquainted with the character of the Kootenai fauna I had named such an obscure specimen, which Mr. Cockle sent me, as vulpina Smith, thinking it probably conspecific with this apparently neighboring species (vulpina was described from Calgary, Alberta). However, it really belongs with incallida, described from the mountains of California. I do not see that lutulenta Smith or quinquelinea Smith are more than varieties of incallida. If this is correct, the species must be known as quinquelinea, as that name has priority by a page.

PARAGROTIS ALTICOLA Smith.

One specimen, August 18. It is darkly colored, the fore wings blackish brown, somewhat bronzy. The characteristic appearance of alticola is not shown, but I nevertheless refer the specimen here as a varietal form. It is not in perfect condition. 
PARAGROTIS GAGATES Grote.

No specimens; one from Mr. Cockle's collection, less reddish in color than my Californian specimens.

\section{PARAGROTIS DECOLOR Morrison.}

Three hundred and sixty-three specimens, July 24, 25, 26, 27, August 3, 5, 6, 11, 12. A very variable species. A specimen in $\mathrm{Mr}$. Cockle's collection has been labeled Chorizagrotis inconcinna Harvey, perhaps by an accidental transposition of labels.

PARAGROTIS ALBIPENNIS Grote.

No specimens; two in Mr. Cockle's collection, September 4.

PARAGROTIS OCHROGASTER Guenée.

Seven hundred and eighteen specimens, July 4, 19, 24, 25, 27, August 1, 3, 5, 7, 12, 16, 17, 21 (Revelstoke). Very variable and running into three rather definite forms, a light clay yellow one (var. illata Walker), a uniform dark brown one (var. turis Grote) and a diversified, strongly marked one, which may be taken as the stem form. Several of the extreme forms were taken in copula, so there is no doubt of the specific identity of all. A large, brown, strongly marked female in Mr. Cockle's collection has been named gagates Grote, but it does not agree with the form so named in the National collection.

\section{PARAGROTIS IDAHOENSIS Grote.}

Five specimens, July 14, 25, August 3, 5, 11. One specimen has the costa and spots pale gray, as in my figure of the type. The others have this color replaced by a lightened shade of the reddish ground color, a little touched with gray.

PARAGROTIS OBELISCOIDES Guenée.

Thirty-three specimens, August 6, 11, 12, 15, 16, 17.

PARAGROTIS REDIMICULA Morrison.

One specimen, August 13.

PARAGROTIS COLATA Grote.

One specimen, August 13 (Sandon, Mr. Currie). It agrees with one that I have under this name from the Yellowstone Park, Wyoming.

$a$ Hampson changes entirely the synonymy of this species, which is No. 1707 in Bulletin 52, U. S. National Museum. He refers all four of the Walker names to other species and refers the variety also elsewhere, leaving only decolor Morrison=campestris Grote as names for this form. This is in contradiction to Smith's previous determinations of Walker's types. 


\section{PARAGROTIS DIVERGENS Walker.}

One hundred and twenty-nine specimens, July 21, 27, 31, August $5,7,16,17$. Two eggs were obtained from a captive female, but were lost on hatching. I have described the mature larva elsewhere. ${ }^{a}$

Egg.-Nearly spherical, base scarcely flattened. Ribs about 44 around the margin, diminishing angularly by confluence, narrow, almost linear, low, the surface flat between them, joined by weak, narrow cross striæ forming square cells. Vertex obsoletely quadrangularly reticulate, smaller at the micropylar rosette, which is not raised. Waxy white; diameter, $0.7 \mathrm{~mm}$.

\section{PARAGROTIS PINDAR Smith.}

Five specimens, August 11, 13, 21 (Revelstoke), and one from Mr. Cockle's collection September 6, 1902. The tone is a little grayer than in Smith's type from Utah, making the costal edging less contrasted. The markings, however, are the same.

\section{PARAGROTIS PLAGIGERA Morrison.}

No specimens. One in Mr. Cockle's collection is so named, and I leave it here with some hesitation. It is brightly marked with ashen whitish; the orbicular is large and very oblique, and altogether it is rather unlike what I have as plagigera. Without a series, however, no certain conclusion can be arrived at.

\section{ANYTUS EVELINA French.}

No specimens. A female in Mr. Cockle's collection was taken September 18, 1901. This species has stood hitherto in our lists as an Hadena. I transfer it to Anytus, following Sir G. F. Hampson.

\section{ANYTUS SCULPTUS Grote, var. PROFUNDUS Smith.}

Two specimens, September 7 (Revelstoke), Sandon (G. C. Robbins), and one from Mr. Cockle's collection September 19. The specimen agrees with Smith's type of profundus, from Brandon, Manitoba. The form is a dark Western variation of sculptus, which is usually light, though I have one from Holderness, New Hampshire, nearly as dark as the Western ones. The name obscums Smith does not deserve even a varietal rank, the male type before me being only a slightly rubbed and indistinctly marked specimen of the variety profundus. The specimens which I associate as female profundus are grayer than the males, with the hind wings darkly shaded. 
MAMESTRA DISCALIS Grote.

Eighty-six specimens, June 23, 30, July 13, 30, August 3, 5, 6, 7, 11, 13, Sandon (G. C. Robbins). Eggs were obtained from several captive females. The larvæ did well at first, but soon showed a tendency to hibernate. Many were actually hibernating at Kaslo on August 12, and only a few were with difficulty forced to the fifth stage. The last stage therefore remains to be described.

Egg. - Two-thirds spherical, evenly rounded, base broad; laid in a large mass. Ribs about 40, low, broad, diminishing to vertex, crested by the sharp vertical reticulations which are, like the cross striæ, distinct, forming regular parallelogramic cells bending down in the hollows. Greenish white, not changing color; diameter, $1.1 \mathrm{~mm}$.

Stage I.-Head bilobed, round, pale brownish, with smoky black spots at the tubercles. Body moderate, normal, joint 12 enlarged, the feet of joints 7 and 8 smaller than the rest, but not greatly so. Whitish, without marks, cervical shield very weak, partly smoky. Tubercles large, brownish black, angularly edged, only the primary ones present, iv stigmatal posterior, ia to iib of thorax separate, iib the largest, all normal. Leg shields faintly dusky.

Stage II.-Head bilobed, shining pale brown with round black spots on the tubercles; width, $0.8 \mathrm{~mm}$. Body moderate, joints 5 to 7 looped up a little, 12 enlarged; whitish green, the folds whiter; dorsal and subdorsal lines faint white, straight; lateral space solidly brown filled; stigmatal band just over tubercle iv, very broad; a soft white shading over subventral area. Feet pale; tubercles round, black; feet of joints 7 and 8 small. Cervical shield concolorous, but without green tint, its tubercles black; abdominal feet dusky without.

Stage III.-Head shining reddish brown, reticulate with darker on the vertex; diameter, $1.1 \mathrm{~mm}$. Body equal, joint 12 a little circularly enlarged. Sordid olivaceous green, checkered by very pale subdorsal patches intersegmentally; dorsal and subdorsal lines broken, narrow, the dorsal bimacular, the subdorsal dotted, bright white. Sides all vinous brown, olivaceous mottled. Substigmatal band with white edges, green filled; subventer and feet pale. Tubercles round, black, distinct; no shields; setæ moderate, pale; feet of joint 7 rather small.

Stage IV.-Head brown with dark brown reticulations; joined into the usual vertical bands; width, $1.7 \mathrm{~mm}$. Body normal, joint 12 scarcely enlarged, feet equal. Brown gray, black dotted reticulate on a brownish ground, especially in a dorsal band of diamond-shaped marks and laterally. Dorsal line white, out into two segmental streaks, the posterior one with a small macular enlargement; subdorsal line a row of fine dots, the space above it and between the dorsal marks lighter. Substigmatal band with white dotted edges, nearly entirely luteous filled. Subventral area luteous, white and black dotted; venter 
greenish. Feet pale, with dark tubercular spots; no shields; tubercles obscure; setæ fine brownish.

Many larvæ hibernated at this point. An interpolated stage also occurred with width of head of $2.1 \mathrm{~mm}$.

Stage V.-Head rounded, bilobed, the apex in joint 2; shining red brown, with dark brown reticulations and vertical bands, the bands irregularly bent inward above clypeus; width, $2.5 \mathrm{~mm}$. Body moderate, joint 12 slightly enlarged. Dead leaf brown, the ground pinkish brown, finely penciled in black. A broad, diffuse lining surrounds the dorsal line which is composed of two white dots posteriorly on the segments and a fine tracing elsewhere, and throws out a faint spur at tubercle ii. The subdorsal space shows the ground color. Sides with obscure oblique lines and outlinings of the substigmatal band in black. Lines else obsolete, the substigmatal with scarcely any pale ground and only a trace of white at its edges. Thoracic feet shining brown; shields and abdominal feet concolorous with body; tubercles and setæ obscure.

Stage VI.-(Not observed.)

MAMESTRA PURPURISSATA Grote, var. CRYDINA Dyar.

Twenty-one specimens, June (Mr. Cockle), June 30, July 2, 8, 14, 18, 19, 27, 30, August 1, 5, 6, 13. This is a racial form, approaching juncimacula Smith in some characters. Eggs were obtained from captive females before the middle of July, and the resulting larvæ were inclined to hibernate on August 15. However, some were forced to the last stage.

Egg.-Laid in a large patch; spheroidal, the top roughened by the ribs. Ribs about 36 at the margin, diminishing to 11 at the micropyle, large, coarse, low and rounded. Surface smooth, irregularly shagreened, traces of long cross striæ between the ribs. Micropylar rosette of pyriform cells contrasted with the otherwise smooth surface; pale yellow, later with a dark-brown ring and spot; diameter, $1.1 \mathrm{~mm}$.

Stage I.-Head rounded, bilobed, rather high, pale brown, spotted thickly with darker brown and a pale streak above. Body slender, moderate; joint 12 slightly enlarged, the feet of joints 7 and 8 very small. No cervical shield, but distinct blackish leg shields. Tubercles round, black; not black on the shield, which has dusky spots behind. Body white, with faint ocherous brown stripes, subdorsal (between tubercles i and ii), lateral, lower lateral (tubercle iii); substigmatal band broadly white pigmented; subventer less whitish; setæ rather long, black; thoracic feet smoky; anal feet, with white stripe outwardly.

Stage II.-Head rounded, the apex in joint 2 , smoky luteous, with dark spots on the tubercles; width, $0.6 \mathrm{~mm}$. Body with a green dilution in the dorsal space each side of the pale dorsal line, the rest of the ground dark vinous brown. Subdorsal line whitish, lateral fainter; substigmatal broad and bright white, venter paler. Feet pale, with 
smoky plates, those of joints 7 and 8 small; tubercles minute, black; no shields.

Stage III.-Head oblique, bilobed, shining brown, faintly darker dotted; width, $1 \mathrm{~mm}$. Body rather slender, joint 12 a little enlarged. Brown, dorsal, subdorsal, and lateral lines fine, white, together with the white tubercles $\mathrm{i}$ and ii dark edged, the edging of the dorsal line submacular intersegmentally. Substigmatal band moderately broad, bright white, with a few brown dottings centrally. Feet pale; no shields.

Stage IV.-Head oblique, the apex in joint 2, pale brown, with dark reticulations and the usual vertical bands, pale below; width, $1.4 \mathrm{~mm}$. Body moderate, normal, a little flattened; joint 12 enlarged. Pinkish brown, shaded with dark and whitish dotted. Dorsal lattice faint; dark intersegmentary spots dorsally; dorsal, subdorsal, and lateral lines white, dotted, dark edged. Tubercles white; substigmatal band broad, pure white, partly luteous brownish filled. Subventer like dorsum; feet pale; setæ pale, moderate; cervical shield of a more luteous shade.

An interpolated stage occurred with width of head $1.6 \mathrm{~mm}$.

Stage V.-Head as before; width, $2.2 \mathrm{~mm}$. Body moderate; joint 12 slightly enlarged. Dorsum creamy brown, dorsal and subdorsal lines white dotted, a faint dark-brown lattice and edging to the dorsal line. Sides darker, brown reticulate, white dotted. Substigmatal band resolved into white spots, filled by the ground color; subventer like dorsum; venter pale. Tubercles white, not large; setæ small. Cervical shield more sordid.

Stage VI.-Head rounded, the apex in joint 2, shining brown, faintly darker reticulated and with traces of the bands above, forming a dark shade; width, $3.2 \mathrm{~mm}$. Body moderate, joint 12 scarcely enlarged, all grayish brown, the markings obsolete, marbled and dotted in blackish. Dorsum faintly broadly pale carneous, the black shaded edgings of the dorsal line showing faintly intersegmentally. Substigmatal band brighter and obscurely white, the other marks scarcely traceable. Tubercles whitish with black hair dots; feet pale; spiracles black edged; cervical shield concolorous, but rather more blackish in shade.

\section{MAMESTRA SEGREGATA Smith.}

No specimens; two in Mr. Cockle's collection, May 14. This species is obviously variable and a good series is needed. Neither of Mr. Cockle's specimens are like the type before me, though I think they are the same species without doubt; gussata Smith seems to be only a variety of it.

Proc. N. M. vol. xxvii-03-58 
MAMESTRA DETRACTA Walker.

Forty-four specimens, June 13, 17, 19, 23, 25, July 2, 8, 19. The color is dark as in neoterica Smith, the size large as in typical detracta Walker. We have here a local form, differing so slightly as not to be worthy of a separate name, yet constant. The Atlantic region detracta is large, the colors rather diversified and contrasted; the Western prairie form neoterica is small with the colors smoother and less diversified, while the Kootenai form is again large but smooth and dark like the priarie one. Eggs were obtained early, but the larvæ grew very slowly and none pupated, all hibernating at various stages of growth. All the stages were observed.

Egg.-Nearly spherical, the apex a little pointed, base scarcely flattened; whitish with streaked red ring and spot. Ribs moderate with reticulation lines running along the vertices which, with the cross striæ, form quadrangular cells; ribs about 40 at the edge; micropyle conically elevated, bearing a circle of pyriform cells surrounded by reticulations; diameter, $1 \mathrm{~mm}$.

Stage I.-Head bilobed, bright brown with darker sutures; width, $0.4 \mathrm{~mm}$. Body robust, normal, joint 12 a little enlarged, feet nearly equal. Whitish slate color, the hemispherical shield with the leg plates and small tubercles black. Skin rather densely dark spinulose; setæ fine, pale, moderate.

Stage 1I.-Head rounded, bilobed, pale brown, a smoky shade on paraclypeus, eyes black; width, $0.6 \mathrm{~mm}$. Cervical shield shining black. Body robust, joint 12 anteriorly enlarged, feet nearly equal. Soft pale brown, vinous shaded, without lines. Tubercles round, blackish; anal plate large blackish but no leg plates; thoracic feet pale; setæ short, pale.

Stage III.-Head shining pale brown, a smoky upright shade and traces of reticulations; width $0.75 \mathrm{~mm}$. Body robust, pinkish red; dorsal and subdorsal lines narrow, white, the dorsal macular on the posterıor edges of the segments; traces of a white substigmatal band intersegmentally. Cervical shield large, black, rather broadly trilineate in white; anal plate similar; leg shields and tubercles brown black, the latter round, moderate. Setæ obscure dusky; joint 12 slightly enlarged.

Stage IV.-Head bilobed, shining pale brown with heavy reticulations and broad, vertical bands of dark brown; width, $1.2 \mathrm{~mm}$. Cervical shield black with three white lines. Body robust, joints 2-4 smaller, 12 enlarged. Dead leaf brown, red-brown reticulate on a pale luteous ground; dorsal and subdorsal lines narrow, whitish, the dorsal distinct on joints 12 posteriorly to 13 , and cutting the black anal plate. No substigmatal or subventral bands, the venter sordid, pale. Tubercles small, round, b]ack; feet pale; setæ obscure. 
This stage lasted 41 days.

Stage V.-Head shining, heavily black reticulate on a brown ground, rounded, the apex in joint 2; width, $1.6 \mathrm{~mm}$. Body robust, joint 12 enlarged, a little narrower before. Soft red brown, finely uniformly dotted reticulate in paler. Dorsal line narrow, white, submaculate except at the ends; subdorsal similar, obsolescent anteriorly, a faint darker brown edging to the dorsal line. Substigmatal band obsolete, showing as a slightly lighter shading over the subventral fold. Cervical shield shining black, slightly elevated. Thoracic feet brown; leg shields quadrate, black.

Stage VI.-Head shining black, luteous dotted above and more so on the sides; clypeus and labrum paler, violaceous; apex in joint 2; width, $2.6 \mathrm{~mm}$. Body robust, short, joint 12 scarcely enlarged, flattened ventrally. Cervical shield large, shining black with three broad distinct white lines. Anal plate similar but only the dorsal line distinct. Thoracic feet brown. Body dead leaf brown, reddish brown, broadly mottled on a pale carneous ground, which contrasts under a lens. Dorsal lines carneous white, broken dotted, subdorsal similar but nearly continuous, subconfluent with the pale ground above; below it a nearly solid brown space; then the sides more mottled with the pale ground color which is more whitish subventrally, but all other trace of the lower lines is lost. Tubercles brown, corrugated, rather large, not elevated. Feet with shining brown shields. Tubercle iv above the center of the spiracle on joints 9 and 10 .

MAMESTRA SENATORIA Smith.

No specimens; one in Mr. Cockle's collection, August 20, agrees very nicely with this Arizonian species. The distribution is unexpected.

\section{MAMESTRA LIQUIDA Grote.}

Three specimens, June 3, 30. Two males brightly colored, one female with the colors subdued and diffused, but the same species, I think.

Egg.--Two-thirds spherical, spheroidally flattened, base flat, the ribs forming lumps at the vertex. Ribs about 35 , diminishing above, capped and separated by the vertical reticulations with which the equally distinct cross striæ form nearly square cells, clear, the angular joinings suggesting as mass of soap bubbles. Vertex reticulate for two rows of cells with a small circle of pyriform ones at the micropyle. Slightly yellowish white; diameter, $0.9 \mathrm{~mm}$.

\section{MAMESTRA RADIX Walker.}

Three specimens, June 23, 25. In spite of so few specimens being taken, five separate broods of the larvæ were raised. Two of the captured specimens were females and readily laid eggs; two egg masses 
were found in the field on separate occasions and matured into the same larva, while Mr. Cockle bred it again from a third collected egg cluster under his number 20.

Egg.-Laid in a high pile, three or four layers deep, irregularly plastered on. Flatly spheroidal, the base well flattened. Ribs about 60 , diminishing irregularly by confluence or alternation toward vertex. Reticulations all over alike, the vertical ones only on the summits of the ribs, not in the bases of the hollows, with the cross lines forming rounded hexagonal cells. Above the ends of the ribs are elongate reticulations, getting very small at the micropyle. Pale yellow; diameter, $0.9 \mathrm{~mm}$.

Stage I.-Head rounded bilobed, pale brown, blackish mottled and with black posterior rim and ocelli. Body normal, uniform, joint 12 enlarged, the feet of joints 7 and 8 short, semilooping; whitish, the food green; tubercles round black, leg plates distinct and black; cervical shield blackish at the edges. Thoracic feet pale; skin minutely sparsely black spinulose; setæ rather long, black, pointed.

Stage II.-Head bilobed, pale luteous, freckled with large gray spots, mouth brown; width, $0.6 \mathrm{~mm}$. Body normal, joint 12 a little enlarged, the feet of joints 7 and 8 very short. Pale green, the food dark; pale dorsal and subdorsal lines indicated. Tubercles small, black; shields concolorous, cervical shield a little shining; feet pale, the abdominal ones with black dots.

Stage III.-Head pale luteous, blackish spotted in irregular bands; width, $0.9 \mathrm{~mm}$. Body moderate, joint 12 humped dorsally a little, feet of joint 7 smaller. Green, dark olivaceous dorsally, pale subventrally. Dorsal and subdorsal lines whitish, dark edged; a shadow of a lateral line; substigmatal white, broad, dark edged above; feet pale; tubercles whitish with black hair dots; setæ small.

Stage IV.-Head rounded, shining, heavily reticulate with smoky brown on a pale luteous ground; vertical bands broad; width, 1.2 mm. Body moderate, joint 12 enlarged a little; green, white dotted, the dorsum with segmentary smoky black diamond-shaped marks, cut by a white broken dorsal line. Subdorsal line fainter, lateral still fainter, smoky edged, the sides shaded nearly to black. Substigmatal band broad, white, slightly reddish centered; subventer only slightly black dotted. Feet pale; tubercles obscure, concolorous.

Stage V.-Head pale brown, shining, very heavily reticulate with dark blackish, forming a vertical band on the lobe and one above eye; width, $1.8 \mathrm{~mm}$. Body normal, equal; joint 12 slightly enlarged. Greenish gray, dotted reticulate in black, edging narrow broken white dorsal, subdorsal and lateral lines, and forming oblique dorsal shades from the incisure forward and downward to the subdorsal line. Sides heavily shaded; substigmatal band broad, white, luteous and reddish filled; subventer pale, sparsely black dotted; no oblique line on thorax; feet pale; a bar on joint 12 at tubercle ii. 
Stage VI. - Head pale whitish luteous, crinkly reticulate with smoky brown, joining in curved vertical band each side of clypeus and suture, and a narrow one from the eye; width, $2.5 \mathrm{~mm}$. Body brown, light brown with white dots and black strigose mottlings. Dorsal and subdorsal lines white dotted; black oblique lines from dorsal posterior to subdorsal line, where they form a broken border, met by lines from dorsal anterior to the black-marked tubercle i, forming a broken lattice; a transverse bar on joint 12; sides black streaked; substigmatal band broadly pale, of the ground color, or pinkish, and shading to the subventer, only slightly strigose, showing by its white-dotted edges. Feet pale; spiracles white; tubercles black marked, obsolete.

MAMESTRA NEVAD $Æ$ Grote.

Six specimens, July 1, 4, 19, 21, August 11. The specimens agree with some from Wisconsin which Professor Smith has picked out from the U. S. National Museum series as representing his canadensis. I think, however, that I really have nevadix Grote, described from the Sierra Nevada of California, or, as is more probable, canadensis is a synonym of nevadx. Mr. F. H. Wolley Dod has sent me specimens from Calgary, Alberta, labelled nevadx, which seem conspecific with the Kaslo ones.

Egg.-Laid in a high pile, four layers deep in part, irregularly heaped up. Flatly spheroidal, base well flattened, often irregularly so. Ribs about 50 at the margin, diminishing variously toward the vertex, fine, close, the reticulations at the summits with the cross striæ forming cells higher than wide, slightly hollowed, the ribs looking beaded under a low power, really waved by the cell areas; vertex reticulate about the micropylar rosette, which is not raised. Pale pearly bluish green; diameter, $0.7 \mathrm{~mm}$; height, $0.4 \mathrm{~mm}$.

Stage I.-Head pale brown with large black spots on the tubercles and small brown freckles over vertex; body moderately slender, semilooping, the feet of joints 7 and 8 small, joint 12 slightly enlarged. Shield pale brown, blackish on the edges and tubercles; tubercles very large, angularly rounded, black, normal; setæ black, pointed; leg plates black; skin sparsely dark spicular.

Stage II.-Head luteous, with brown tubercular spots; width, 0.55 mm. Body rather slender, contracted somewhat subventrally, narrowed at joint 11, joint 12 enlarged a little. Translucent green; dorsal, subdorsal, lateral, and broad substigmatal lines a little more whitish than the ground color. Feet pale; tubercles round, black; cervical shield a little smoky.

Stage III.-Head bilobed, shining brownish luteous, dark spots on the tubercles and small freckles over vertex; width, $1 \mathrm{~mm}$. Body moderate, narrowed at joints 10 and 11, 12 enlarged dorsally, feet of joints 7 and 8 small. Dark green dorsally; dorsal, subdorsal, and 
faint lateral lines white, dark green edged; space between lateral and substigmatal lines all dark green. Substigmatal band broad, white; subventer green, shaded with dark; feet paler. Tubercles all black, round, not large, pale ringed minutely.

Stage IV.-Head pale brown, freckled over the vertex and most of the surface, except the clypeus, with fine strigæ; tubercles in black spots; a pair of little dots at apex of paraclypeus; width, $1.8 \mathrm{~mm}$. Body moderate, joint 12 enlarged. Green, strongly shaded with blackish green, edging the broken white dorsal, subdorsal, and lateral lines and forming traces of a dorsal lattice; solid on the sides about the broad, white substigmatal band. Subventer likewise dark, but the feet pale. Tubercles white, with black hair dots; setæ fine; no shields; the lines reach the ends; thoracic feet smoky ringed.

An interpolated stage occurred with width of head $1.7 \mathrm{~mm}$.

Stage V.-Like the next stage; width of head, $2.2 \mathrm{~mm}$.

Stage VI.-Head rounded, the apex in joint 2, luteous, heavily circularly mottled with dull brown, with the usual vertical bands; width, $2.8 \mathrm{~mm}$. Body moderate, joint 12 gently enlarged, feet equal. Ground color creamy brown, heavily mottled in black and nearly obscured. Dorsal and subdorsal lines white, dotted, the subdorsal the heaviest. Oblique black shades in the dorsal space; tubercle ii large, white. Sides like the dorsum, but pale by the absence of the oblique shades, sparsely white dotted. Substigmatal band white dotted, filled by the ground color; subventer like the sides. Thoracic feet red brown, the abdominal ones pale, whitish. Tubercles and setæ obscure.

\section{MAMESTRA SUBJUNCTA Grote and Robinson.}

Nine specimens, June 13, 16, 25, July 2, August 11 (bred), 15 (bred), 16 (bred). Through some error Mr. Cockle has this species named canadensis in his collection.

Egg.-Laid in a large patch, in part in two layers. Flatly spheroidal, almost disk-like; 50 vertical ribs, low, slight, close together, their summits bearing the longitudinal reticulations, the cross-striæ of which form quadrangular cells. Reticulations equally distinct, alike, neat, narrow, sharply raised. Summit broadly elongate-hexagonally reticulate, the micropyle with a circle of pyriform cells. Pure white, later faintly purplish gray; diameter, $0.7 \mathrm{~mm}$.

Stage 1.-Head round, bilobed, shining translucent pale brownish luteous, faintly blackish freckled, eye black, mouth brown. Body slender, normal, semilooping, joint 12 enlarged, the feet of joint 7 and 8 very short. Whitish, shields concolorous, tubercles moderate, black; alimentary canal reddish in anterior half of body. When fed the larvæ are green; setæ long, black.

Stage II.-Head rounded, translucent pale luteous, ocelli black; width, $0.5 \mathrm{~mm}$. Body moderate, semilooping, feet of joints 7 and 8 
small; joint 12 enlarged dorsally. Pale green, shaded with olivaceous blackish, leaving narrow dorsal, subdorsal, and lateral pale straight lines. Stigmatal band whitish, illy defined below from the pale subventer. Tubercles small, black; feet pale.

Stage III.-Head round, the apex slightly in joint 2; green, ocelli black; width, $1 \mathrm{~mm}$. Body normal, joint 12 slightly enlarged, feet nearly equal, those of joint 7 only a little reduced. Green, dorsal and subdorsal lines narrow, white, blackish green edged, this color mottling the ground a little. Substigmatal band broad, white above, shading to the subventral color below, edged above with blackish green, leaving a lateral defined line of the ground color. Subventral region slightly dark-marbled; hair dots black in a pale rim; feet pale. Other larvæ were faintly brown shaded.

Stage IV.-Head rounded, the apex in joint 2; whitish luteous, reticulate with smoky brown over the lobes; width, $1.5 \mathrm{~mm}$. Body sordid green, dotted and reticulate with olivaceous green, edging the lines and forming an obscure lattice in the dorsal space. Dorsal, subdorsal and lateral lines white, narrow, broken; stigmatal band broad, white, covering the spiracle except on joints 2 and 12 , dark-edged above, greenish-filled below; a few white dots scattered over the surface. Feet all pale; spiracles black-rimmed; joint 12 slightly enlarged; feet nearly equal.

Stage $V$.-Head whitish luteous, the reticulations forming a band on the lobe and a small one from the eye; width, $2.1 \mathrm{~mm}$. Body normal, joint 12 scarcely enlarged; pale brown without green tint; dorsal, subdorsal, and lateral lines broken and lost in the ground color, dotted reticulate with white and dark brown, forming irregular narrow oblique dark lines on the segments posteriorly forward and downward, obscurely joining a dark band stigmatally, forming a transverse subdorsal bar on joint 12. Stigmatal band lost in the ground color, a red line filling it above, whiter than the subventral area, which is dotted like the dorsum, but with more white and less brown. Feet pale; tubercles small, white, obscure.

Stage VI.-Head rounded, the apex in joint 2, pale brown, shining, dark brown reticulate, with broad indistinct vertical bands and a band from the eye; width, $3 \mathrm{~mm}$. Body normal, joint 12 very little enlarged. Pale brown, tessellated with blackish, dotted and reticulate. The blackish color forms subdorsal bars and dorsal spots, smoky and diffuse, transverse and squarish on joint 12; a broad lateral line indicated in pale. Substigmatal band pale, reddish mottled and all dark reticulate like the body; subventer dotted and reticulate. Feet and venter pale; tubercles whitish, obscure. 


\section{MAMESTRA GRANDIS Boisduval.}

Four specimens, June 7, 13, 23, July 14, and one from Mr. Cockle's collection June 14. Mr. Cockle has the species labeled nevadx, but it does not agree with Grote's description of that form. Prof. J. B. Smith is the authority for the name, but not improbably some confusion in the labels has occurred. The specimens agree closely with Eastern grandis, and, though a trifle smaller, there is scarcely enough difference to define even a local race.

Egg.-Laid in a large patch. Flatly spheroidal, base flattened but little; 30 vertical ribs, diminishing by alternation, broad, rounded, crested by the longitudinal reticulations, but weakly so, the cross striæ likewise weak, shagreened wrinkly over all. Pale yellow, later with a purple ring and spot; diameter, $0.6 \mathrm{~mm}$.

Stage I.-Head strongly bilobed, shining sordid luteous, eye black. Body semilooping, feet of joints 7 and 8 short, cylindrical; joint 12 enlarged. Transparent whitish, alimentary canal red; tubercles large, setæ short, black, stiff. Cervical shieid faintly luteous with black spots at the tubercles, two detached setæ; leg shields smoky. Tubercles normal, large, black, no subprimaries; ia to iib on thorax separate, ia and ib small.

Stage II.-Head bilobed, whitish, smoky shaded, shining, eye black; width, $0.6 \mathrm{~mm}$. Body equal, normal, feet of joints 7 and 8 small, joint 12 not enlarged. Whitish, green from the food, with olivaceous shading, leaving pale dorsal, subdorsal and lateral lines, the space below the lateral line darker. Below tracheal line to venter sharply paler. No shields; feet pale; tubercles moderate, black, in pale rings; setæ fine, short.

Stage III.-Head bilobed, held flatly, shining pale brown, thickly mottled with blackish over the apices of the lobes; width, $1.1 \mathrm{~mm}$. Body normal, depressed anteriorly, joint 12 a little enlarged dorsally. Dorsum blackish green, subventer light green; dorsal, subdorsal and lateral lines narrow, white, dark edged; space between lateral and stigmatal lines black; substigmatal band broad, white, greenish filled. No shields, the lines continuous; feet pale, the pair on joint 7 small, those of 8 nearly equal to the ones on 9 and 10 . Tubercles minute, black; setæ moderate, brown.

Stage IV.-Head round, low bilobed, broad, shining translucent white, brown reticulate, showing faintly brown vertical bands on the lobes and upward from the eye; width, $1.7 \mathrm{~mm}$. Body normal, joint 12 enlarged a little, feet equal. Dorsum dark slaty olivaceous, black crinkled lines thickly on an ochraceous ground, edging the faint narrow pale dorsal and subdorsal lines. A dark vinous band between the obsolete lateral white line and the substigmatal one. The latter broad, white, pale vinous filled; subventral space white, translucent, waxy, 
lightly blackish reticulate. Feet pale; tubercles whitish with black hair dots; setæ moderate, dusky.

Stage V.-Head shining pale brown with dark brown bands and reticulations; width, $2.8 \mathrm{~mm}$. Body smoky olivaceous dorsally, reticulate in dark brown and speckled with white, shading to vinous laterally. Dorsal and subdorsal lines obsolete, linear, pulverulent, white; blackish patches at the tubercles. Stigmatal line linear, white, being the upper edge of the substigmatal band, its lower edge lost in the waxy white subventral area. A little vinous centers the subventer with some white and black specks. Feet pale; tubercles and setæ minute.

Stage VI.-Head sordid luteous, reticulate in brown, vertical bands and one from eye moderately distinct, the round, shining apex slightly retracted in joint 2 ; width, $3.6 \mathrm{~mm}$. Body robust, equal, joint 12 scarcely enlarged, feet equal. Dull sordid purplish, shading to whitish below the spiracles. Feet pale, no distinct marks. The dorsum is dotted in white and strigose reticulate in black on a lilaceous ground; traces of the white dorsal line and the upper and lower edges of the substigmatal band show by an alignment of dots only. Cervical shield slightly sooty shaded. Tubercles minute, setæ fine, obscure; spiracles white, black rimmed.

\section{MAMESTRA INVALIDA Smith.}

Three specimens, July 2, 25, August 11, and one from Mr. Cockle's collection June 24. A captive female deposited eggs. The larvæ passed but five stages according to my notes.

Egg.-Laid in a large patch, not touching. Two-thirds spherical, the base roundedly flattened; ribs about 40, finely angularly waved, decreasing irregularly toward vertex; no vertical reticulations in the hollows; cross striæ fine, nearly obsolete; vertex weakly reticulate from the ends of the ribs to the slightly raised micropyle, which bears a circle of pyriform cells. Pale yellow, later washed with reddish all over the upper part; diameter, $0.85 \mathrm{~mm}$.

Stage I.-Head rounded bilobed, pale brown with slight brown spots on the tubercles; antennæ rather short. Body moderate, norma?, joint 12 a little enlarged, shields uncornified. Whitish, the tubercles moderate, brown, normal. Feet of joints 7 and 8 small; skin minutely dotted spicular, subcutaneous layer rounded vacuolar; setæ black, pointed.

Stage II.-Head round, bilobed, greenish, thickly brown dotted except a streak on lobe above and clypeus; width, $0.8 \mathrm{~mm}$. Body moderate, green, olivaceous shaded, leaving dorsal, subdorsal, lateral, and broad stigmatal lines pale. Shields concolorous; tubercles small, round, black. Feet pale, those of joints 7 and 8 smaller; joint 12 a little enlarged. 
Stage III.-Head green, the paraclypeal tubercles blackish; width, $1.1 \mathrm{~mm}$. Body dark olivaceous green; dorsal and subdorsal lines narrow, dark edged, lateral wavy, obscure, stigmatal broad, pale; subventer olivaceous; feet pale; tubercles and setæ obscure.

Stage IV. (Green form)-Head green, faintly darker reticulate; width, 1.9 to $2.1 \mathrm{~mm}$. Body uniform, rather slender; joint 12 enlarged dorsally in a low hump which appears brighter by its markings. Green, dorsal, subdorsal, and broad stigmatal lines white, dark-green edged, throwing a series of broken green obliques from subdorsal anterior to dorsal posterior, forming a bar on joint 12. Sides dark marbled, subventer less so; stigmatal line straight, touching spiracle except on joints 2 and 12 . Feet green; tubercles white obscure. (Brown form)-Head pale brown, heavily recticulate in dark brown, forming an erect stripe on face edging clypeus and median suture. Body brown, reticulate in dark brown, marked as in the other form, but the oblique and bounding shades heavier, the light lines nearly completely light brown filled. Tubercles white, but no other white dots. No shields; feet equal.

Stage V.-Head brown, reticulate in darker and with distinct vertical bands; width, $3.3 \mathrm{~mm}$. Large, robust, equal; joint 12 a little enlarged. Light ocherous brown, with subdorsal blackish shaded oblique bands, squarely terminated on joint 12, fainter on the thorax. Dorsal line rather broad, pale; subdorsal indicated by dark edging lines; sides black recticulate, light, not shaded; substigmatal band yellowish, with a narrow dark edge above; subventer brown recticulate. Setæ small, brown; feet pale; cervical shield darkened, trilineate.

\section{MAMESTRA TRIFOLII Rottemburg.}

One specimen, much worn, taken August 1 by Mr. Cockle.

\section{MAMESTRA OREGONICA Grote.}

No specimens; one in Mr. Cockle's collection, July 12, 1902. I am inclined to regard this form as distinct from trifolii.

\section{MAMESTRA ASSIMILIS Morrison.}

Seven specimens, July 6, 8, 25, 30, August 5. The specimens have grayer, more diversified wings than the Atlantic region form, which is a smooth black. This is probably a local race, which I leave to be named by some enterprising student. The larva is remarkably pretty. The Kaslo ones were black, but this color is not constant, as I took one on brake (Pteris) at Shawnigan Lake, on Vancouver Island, in which the ground color was green. The larvæ had but five stages.

Egg. - Spheroidal with flattened base; ribs fine, about 40 around the margin, diminishing by confluence above. Reticulations distinct, both 
vertical and transverse, the latter forming cross-striæ with nearly square cells; no vertical lines in the hollows. Vertex reticulate between the ends of the ribs and the micropylar rosette. Pale yellow: diameter, $0.8 \mathrm{~mm}$.

Stage I.-Head round, bilobed, pale whitish luteous; tubercles blackish; mouth brown. Body moderate, joint 12 slightly enlarged, feet of joints 7 and 8 smaller. Whitish, cervical shield pale brown with black tubercles, the other tubercles very large, black, round, i and ii nearly in line, ia and ib of thorax small. Leg plates black; skin sparsely dark spicular.

Stage II.-Head shining luteous with smoky blackish spots on the tubercles; width, $0.6 \mathrm{~mm}$. Body moderate, joint 12 slightly enlarged; some look very slender, other's more robust. Shield greenish luteous, nearly concolorous; body light green, the ordinary lines of the ground color broad, about equal to the intervening spaces, which are olivaceous dark green, and may be described as addorsal, upper and lower lateral. Feet pale; those of joints 7 and 8 short. Tubercles minute, blackish, with the setæ inconspicuous. Later the ordinary lines show pale, the dorsal obscure, the subdorsal yellowish white, the lateral obscure, the substigmatal line like the subdorsal. The colors fade very markedly during the stage.

Stage III.-Head green, dotted with brown over the upper part; width, $1.1 \mathrm{~mm}$. Body moderate; joint 12 scarcely enlarged, darkly and contrastingly colored. Black above, dorsal and lateral lines obsolete, dotted; subdorsal and substigmatal alike, broad, greenish white. Subventral region and feet pale greenish, black mottled. Shields concolorous; tubercles black, minute.

Stage IV.-Head with the apex in joint 2, the median sutures depressed, shining luteous, with a few brown spots above; width, 2 mm. Body uniform, velvety olivaceous black; broad, equal, subdorsal and substigmatal bards of pale yellow, even, reaching the ends, no shield, the substigmatal only narrowly black below; subventral region and feet pale greenish, but retracted. Traces of a narrow dorsal line; tubercles and setæ obscure.

Some of the larvæ had heads 1.5, $1.6 \mathrm{~mm}$., etc., while ono had a $2.4 \mathrm{~mm}$. head, probably representing the missing stage $\mathrm{v}$ that was not observed in the larva specially under observation. The colors were the same.

Stage VI.-Head slightly bilobed, the vertex in joint 2, light red, finely mottled; width, $3 \mathrm{~mm}$. Body velvety black; broad subdorsal and substigmatal bands light yellow, narrowly white at the edges. Lower subventral region and feet outwardly light red; anal flap hrown-black. Thoracic feet pale luteous; venter pale whitish; tubercles obsolete; setæ fine, black; spiracles white. 
MAMESTRA INGRAVIS Smith.

One specimen, July 25, and one from Mr. Cockle's collection, May 2. The species varies in the width and distinctness of the submarginal pale lilac shading.

MAMESTRA ADJUNCTA Boisduval.

Two specimens, June 25 , July 16.

Egg.-Laid in a large irregular patch. Two-thirds spherical, the base flattened; ribs about 56 around the margin, diminishing by confluence, pitted-waved; cross-striæ nearly obsolete; vertex above the ribs reticulate; micropyle raised. Pale yellow; diameter, $0.6 \mathrm{~mm}$.

\section{MAMESTRA TACOMA Strecker.}

Two specimen , June 3, July 22. This species was determined for Mr. Cockle by Professor Smith and seems to be correctly so, as the specimens agree with Strecker's description. The form was previously unknown to me.

Egg.-Laid in a large mass, adherent. Spheroidal, the base well rounded, the top roughened by the ends of the ribs; ribs about 25 , broad, narrow at the tip, decreasing toward the vertex which is reticulate; cross-striæ distinct, about as high as the ribs, forming nearly quadrangular cells. Pale yellow, later with brownish dotted ring and spot; width, $0.8 \mathrm{~mm}$, height, $0.6 \mathrm{~mm}$.

Stage I.-Head rounded, bilobed, long, pale brown, slightly streaked, the sutures darker. Body slender, cylindrical, normal, joint 12 a little enlarged, semilooping, the feet of joints 7 and 8 smaller. Translucent yellowish, the food green; tubercles small, neatly black; shields of the abdominal feet blackish. Cervical shield reduced, luteous; no marks.

Stage II. - Head luteous, faintly brownish reticulate and with curved lines each side of the clypeus; eye black, mouth brown; width, 0.6 mm. Body normal, uniform, joint 12 enlarged, the feet of joints 7 and 8 short. Pale green, striped with olivaceous blackish; a broad dorsal line, two narrower lateral ones and broad subventral one, leaving a subdorsal, lateral and broad stigmatal pale green lines. Feet pale; tubercle dots black in pale areas; setæ short, dark; no shields.

Stage III.-Head shining pale green, vertex a little smoky, eyes black; width, $1 \mathrm{~mm}$. Body pale green with broad, straight stripes of velvety green, subdorsal, lateral, suprastigmatal, subventral, the subdorsal broad and darker at its edges. Shields concolorous, lined, but the green is more olivaceous on them. Tubercles pale; hair dots and setæ black; small.

Stage IV.-Head shining green, the vertex more whitish and faintly dusky reticulate, ocelli black; width, $1.7 \mathrm{~mm}$. Markings as before, 
but the subventral band is dotted and obsolete, the substigmatal space forming a broad greenish white band. Suprastigmatal band paler than the subdorsal and lateral; subdorsal broadly geminate, blackishgreen dotted filled.

Stage V.-Head, $2.1 \mathrm{~mm}$. Lateral and suprastigmatal dark bands more vacuolated dotted and obscurely geminate by their edges. Otherwise no change; spiracles white.

Stage VI.-Head erect, bilobed, the apex in joint 2; green, a little yellowish over the lobes and faintly darker green reticulate; width, $3.1 \mathrm{~mm}$. Body all much as before but still paler. Soft velvety yellow green, faintly dotted and reticulate in darker. Subdorsal band defined only by its edges, giving a smoky dorsal geminate line, the space between subdorsal and lateral forming dark bands, giving a pale subdorsal line blackish-green edged; an obscure white stigmatal line. Skin folds yellowish; tubercles small, dark; iv below the center of the spiracle. The larva is almost unmarked, especially as the colors pale with growth.

This is a tree-feeding Noctuid, as is very evident from the coloration. The food plant is probably the thimbleberry (Rubus nutkanus).

MAMESTRA STRICTA Walker.

Seven specimens, August 20 (West Robson), 25 (Victoria), 31 (Shawnigan Lake), September 1 (Shawnigan Lake), 2 (Wellington), 5 (Shawnigan Lake).

MAMESTRA OLIVACEA Morrison, var. PETITA Smith.

Eight hundred and forty-three specimens, June 25, July 21, 22, 25, 27, 31, August 5, 6, 7, 12, 15, 21 (Revelstoke). As some difference of opinion has arisen concerning the proper placing of the forms allied to olivacea, I will here discuss the matter. In Bulletin No. 52 of the U. S. National Museum, I referred comis Grote as a variety of olivacea with davena Smith, Jucina Smith, altua Smith, megarena Smith, and petita Smith as synonyms; rectilinea Smith as a second variety with circumcincta Smith and obnigra Smith as synonyms. To this conclusion Professor Smith expresses dissent, ${ }^{a}$ and states his adherence to the views expressed in a previous paper. ${ }^{b}$ After studying the 1,500 specimens from Kaslo, the material in the National Museum and Professor Smith's slides, I am disposed to admit two distinct species, though they run very closely. I have separated the Kaslo catch into two series, which typify olivacea and comis and, though there may be doubt about a few specimens, I can broadly separate them. Olivacea is smaller, without tendency to green, and the discolorous spot at anal

$a$ Jour. N. Y. Ent. Soc., XI, 1903, p. 14.

${ }^{b}$ Trans. Am. Ent. Soc., XXVII, 1901, p. 230. 
angle is diffuse; comis is larger, with a certain tendency to green, the spot at anal angle of primaries smaller, concrete, especially marked in the females. The male genitalia offer no sharp contrast. I will now refer to the names proposed by Professor Smith.

1. circumcincta Smith. This is obviously only a very dark form of stricta. I was in error in referring it to olivacea. The Kootenai form of stricta is not dark, judging from the single specimen I obtained as I was leaving the place, though it might pass for cinnabarina Grote. Professor Smith's form is from the Sierra Nevada of California.

2. rectitinea Smith. The female types before me are from Sierra Nevada, California. They are normal females of comis.

3. Tucina Smith, altua Smith, megarena Smith. These are admitted by the author to be but races of olivacea. They should not have been listed as species. Altua and megarena are from the same faunal region and should be made synonymous.

4. davena Smith. I have the male type. I can not match it exactly in the same sex from the Kaslo catch, though the faunal region is the same. It is a somewhat aberrant specimen. A male comis from Wellington, Vancouver Island, is nearly its exact mate and a female from Kaslo represents the same form. Smith's slide of the male genitalia shows some differences. The piece is narrower at the end, less spinose. The single specimen, however, is not convincing and I am inclined to view it as varietal.

5. obnigra Smith. The female type before me is only comis Grote.

6. petita Smith. This was described from one male and three females. I believe the male was comis, the females olivacea. The latter I can match from Wellington and the males accompanying them resemble altua and do not show the peculiar character attributed to the genital structures in Smith's figure. This slide is before me and is only, I think, a distorted specimen. The spine that stands up so strangely has been misplaced from its normal position by pressure, while its apparent slenderness is due to its being seen edgeways. If replaced, I think nothing different from the usual comis form would be seen.

Besides these, Smith has described vau-media and incurva, which he refers in this neighborhood. They are not before me, but I have little doubt that vau-media is olviacea and will replace the name altua, while incurva is compared with anguina and therefore is probably not referable to this group.

Allowing now every possible latitude for geographical forms, I place the names thus:

OLIVACEA Morrison ....................... Atlantic region.

obscurior Smith.

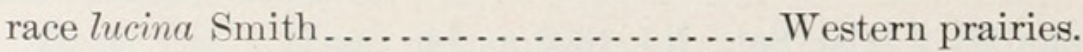

race altua Smith (=? vau-media Smith) ..... Rocky Mountains.

megarena Smith.

race petita $\mathrm{Smith}$.

Pacific coast and mountains. 
COMIS Grote. .Pacific coast and mountains adjoining.

obnigra Smith.

rectilinea Smith.

male petita Smith.

davena Smith.

This arrangement leaves the name petita Smith for the Kootenai form, about which there seems some confusion. Perhaps a separate name is not needed, as the form runs so near typical olivacea. The name petita, however, may properly be restricted to the female types, as the male is a synonym of another species and was characterized from a distorted structure, and this name will apply to the northwestern race of olivacea if a separate name is desired.

Egg.-Three-fourths spherical, the base flat, the apex roughened by the ends of the ribs; ribs about 30 , diminishing toward the vertex, neatly waved, with obsolete cross-striæ; vertex confused, the micropyle slightly raised. Pale yellow with dull red vertical ring and spot; diameter, $0.75 \mathrm{~mm}$.

Stage I.-Head slightly bilobed, shining black. Body normal, joint 12 not enlarged, feet of joints 7 and 8 small; whitish, the large cervical shield, feet, tubercles and plates black. Tubercles rather large, brownblack; cervical shield shining; setæ long, bulbous-tipped; skin finely dark granular.

Stage II.-Head round, dull black; width, $0.5 \mathrm{~mm}$. Body moderate, a little flattened, joint 12 slightly enlarged dorsally. Dark brown, dorsal and subdorsal lines pale, broken, darker edged, traces of a lateral line; substigmatal line broad, all pale, sordid. Tubercles round, black, elevated; setæ long, glandular tipped, dark at base, curving backward and forward; thoracic feet black.

Stage III.-Head dark brown, the sutures black, clypeus pale brown; width, $0.85 \mathrm{~mm}$. Body robust, a little squarely flattened, joint 12 slightly angularly prominent, folded. Dark, the skin granular; subdorsal region pale ocherous, indicating a segmentary widening of the dark dorsal band, edged below by a straight black band. Sides nearly uniformly dark, the subventral region lighter below the fold. Tubercles small, black; setæ coarse, stiff, the tips truncate and black; shields concolorous.

Stage IV.-Head small, rounded, dull dark brown, a black V-mark over the clypeus and paler streak on vertex; width, $1.3 \mathrm{~mm}$. Body robust, flattened, resembling a piece of dirty wood, stiff, sluggish, granular, the setæ stiff with enlarged tips and alternating in direction. Dorsal space wood-brown with a black dorsal diamond-shaped marking. Subdorsal line broad, whitish, with central dark line and blackish upper border, below black with a lateral waved pale line and a broad parallel dilution below it. Substigmatal band broad, waved, whitish, brown dotted; spiracles small, black; subventer obscure brown. Feet, pale; tubercles, black, slightly elevated. 
Stage V.-Head, 2 and $2.05 \mathrm{~mm}$. All as before, but brighter after the moult, though soon becoming as dull as before. Setæ white, stiff, thick, subcapitate. Head pale brown, dull, subpruniose, with black reticulations and bands.

The larvæ had but five stages. They are concealed ground feeders, eating any low plant, mostly by night. The pattern of coloration and habits as well are identical with those of Mamestra laudabilis Guenée. ${ }^{a}$

\section{MAMESTRA COMIS Grote.}

Six hundred and sixty-five specimens, June 16, 25, July 19, 27, 31, August 3, 5, 6, 7, 12, 16, 17. The larva greatly resembles that of olivacea Morrison. I did not notice any differences while they were alive, but the inflated comis are pinker than the olivacea similarly prepared, while the relative distinctness of the markings is somewhat different, giving the impression that we have to do with distinct species.

Egg.-Two-thirds spherical, base not strongly flattened, more or less irregularly compressed; vertex roughened by the ends of the ribs; ribs about 40, diminishing by alternation, angularly undulate, the sides pitted by the hollows, the reticulations indistinct. The ribs end in a circle where the surface is radially grooved; micropyle elevated, with a circle of pyriform cells. Pale yellow; diameter, $0.75 \mathrm{~mm}$.

Stage 1.-Whitish, the head large; cervical shield, anal plate, and large tubercles black. Setæ long, curved, bulbous tipped. Feet of joints 7 and 8 very short; the body is robust, joint 12 scarcely enlarged.

Stage II.-Head shining black; width, $0.5 \mathrm{~mm}$. Body moderate, equal, a little flattened, sordid green, shaded with brown, leaving dorsal, subdorsal, lateral, and broad substigmatal pale lines. Tubercles small, black, a little elevated; setæ coarse, black, subcapitate.

Stage III. - Head, $0.85 \mathrm{~mm}$. As in the next stage.

Stage IV.-Head, $1.3 \mathrm{~mm}$. The description of the corresponding stage of olivacea may be repeated for this.

Stage V.-Head, $2.1 \mathrm{~mm}$. As in the previous stage, but brighter after the moult. The dorsal shaded diamond-shaped markings are distinct. The description of olivacea will apply with the exceptions noted above.

\section{MAMESTRA ILLAUDABILIS Grote.}

Nine specimens, June 25, July 2, 20, 21 (Bear Lake), 29, 31, August 3,6 . This has been referred as a local variation of the Eastern laudabilis Guenée, but I am disposed to consider it a true species. It is constantly smaller than laudabilis and more darkly colored. The 
small size would not be expected in a Western race of an Eastern species, since these are always larger.

Egg.-Spheroidal, the basal half more flattened than the upper half; about 40 vertical ribs, diminishing by alternation toward vertex, angularly undulate, the sides pitted by the hollows, the vertex with zigzag crest, but the reticulations not distinct. The ribs end in a circle where the surface is radially grooved; micropyle elevated, with circle of pyriform cells. Pale yellow; diameter, $0.9 \mathrm{~mm}$.

Stage I.-Head slightly bilobed, round, convex before, clypeus high; brown-black, clypeus paler; width, $0.3 \mathrm{~mm}$. Body robust, joint 12 slightly enlarged, the feet of joints 7 and 8 short. Whitish, food reddish anteriorly; cervical shield large, black. Tubercles small, blackish; setæ long, pale, swollen-tipped, curved. The cervical shield has pale spaces around the tubercles. Skin minutely dusky, granular.

Stage II.-Not observed; the description of Mamestra Zaudabitis in the corresponding stage will probably suffice.

Stage III.-Head dark sordid brown with long pale setæ; width, $0.6 \mathrm{~mm}$. Body moderate, sordid brown with narrow faint whitish subdorsal and lateral lines. Tubercles round, black; setæ long, fine pale, curved, with enlarged tips. Skin minutely dark granular.

Stage IV.-Head dull black, paraclypeus, mouth, small brown spots on faces of lobes and in vertical suture pale brown; width, $1 \mathrm{~mm}$. Body robust, rather squarely flattened, joint 12 slightly enlarged, folded; feet equal. Skin densely pale, papillose granular; ground color dark brown, lines obsolete; subdorsal region lighter, edged below by a velvety black band which is widened on the segments, broken on thorax. Sides irregularly marked. Setæ thick, the tips widened. Shields concolorous; tubercle ii conspicuous by a cluster of light granules; a light subdorsal patch on joint 12 anteriorly.

Stage V.-Head rounded, the apex in joint 2 heavily reticulated in dark brown on a pale ground, almost black; width, $1.8 \mathrm{~mm}$. Body robust, quadrately flattened, no shields; densely papillose granular. Black mixed with brown; tubercle ii surrounded by a ring of pale papillæ, especially prominent on joints 12 and 13 . Subdorsal region of joint 12 and anal flap washed with pale. Subdorsal line pale with deep black edge below; subventral fold lighter; lines obsolete. Setæ thick, pale or dark, widened toward the tips. Papillæ concolorous with the markings.

The larvæ pupated in the earth at the end of this stage, but no moths emerged.

MAMESTRA SUTRINA Grote.

No specimens; one from Mr. Cockle's collection July 12, 1902.

$a$ Can. Ent., XXXV, 1903, p. 273.

Proc. N. M. vol. xxvii-03-59 
MAMESTRA MUTILATA Smith.

Two specimens, August 13 (Sandon, Mr. Currie); September 8 (Glacier). The two specimens are not closely similar. The male is mutilata Smith, the female rainierii Smith, but I can not regard them as separate.

\section{MAMESTRA LOREA Guenée.}

Thirty-eight specimens, June 13, 16, 17, 23, 24, 25, 30, July 2, 8, 22. An early species. Eggs were obtained in season, but I could not carry the larvæ beyond stage iv, they showed such a persistent tendency to hibernate. They were fed on dead leaves.

Egg. - Two-thirds spherical, base round, not flat, easily detached and rolling. Ribs about 40, rather sharply narrow and straight, diminishing at summit where they become low and less distinct. Reticulations scarcely indicated, cross-striæ obsolete; vertex broadly smooth, obsoletely reticulate; micropyle slightly raised with crown of small pyriform cells. Pale yellow, later dark red all over the vertex; diameter, $0.7 \mathrm{~mm}$.

Stage I.-Head rounded, pale brown, eye black. Body robust, normal, joint 12 slightly enlarged. Cervical shield pale luteous; body whitish, finely dusky, spicular granular. Tubercles small, brownish; setæ long, pale, with enlarged tips.

Stage II.-Head bilobed, erect, pale brown, the vertex darker; width $0.45 \mathrm{~mm}$. Body robust, joint 12 scarcely enlarged; whitish sordid, dark from the alimentary canal, the incisures folded. Dorsal and subdorsal lines barely indicated; tubercles round, black; setæ moderate, capitate; feet pale, those of joint 7 a little smaller.

Stage III.-Head round, dull dark brown, darker shaded centrally; width $0.7 \mathrm{~mm}$. Body robust, flattened, equal; ocherous subdorsally, a series of wide dorsal diamond-shaped marks, lighter centrally and cut by a very obscure, pale dorsal line. Sides mottled in brown black like the dorsum. Shields concolorous; tubercles small, black; setæ stiff, pale, subcapitate, alternating forward and backward; feet pale, the pair on joint 7 smaller.

Stage IV.-Head round, pale brown, with obscure darker reticulations and bands; width $1 \mathrm{~mm}$. Body robust, flattened, equal, sluggish. Color as before.

The concluding stages remain to be described.

MAMESTRA LARISSA Smith.

One specimen, June 13, and two from Mr. Cockle's collection June 2 and 25, 1902, which he has kindly allowed me to keep. Mr. Cockle says the species was not rare in 1902, but it certainly was so in 1903 . It is very close to pensilis Grote in appearance. 
MAMESTRA PENSILIS Grote.

One hundred and forty-three specimens, July 25, 27, August 3, 4, $5,6,7,13,15,17$. The species is very near vicina Grote. I do not agree with the manner in which Prof. J. B. Smith has separated these forms in the U. S. National Museum collection. I would refer the New York, Texas, Colorado, and Arizona specimens to vicina, the Vancouver Island and California ones to pensitis.

Eggs were obtained, but not very early, and the larvæ refused to proceed beyond stage ii before hibernating. They were fed on dead leaves.

Egg.-Laid in a mass under a piece of paper in the jar, which was glued to the glass by them. Two-thirds spherical, conoidally narrowed above, base flattened, somewhat irregular. Ribs about 48, not diminishing till the edge of the large vertex, where is a mass of irregular crumpled ridges. Sides of ribs waved, crossed by faint striæ, which meet at an angle in the depressions, these being without flat bottom. Micropylar rosette raised. Pale yellow, with a red ring and spot; diameter, $0.6 \mathrm{~mm}$.

Stage I.-Head rounded, wide, with the cervical shield, plates, and tubercles brown black. Body white, densely dark granular; tubercles large, angular; setæ with clear bulbous tips, rather long. Body robust, joint 12 enlarged, the feet of joints 7 and 8 smaller.

Stage II.-Head rounded, shining black, mouth brown; width 0.4 mm. Cervical shield, anal plate, leg plates, and round tubercles black. Body robust, equal, sordid, dark brown, with very faint whitish dorsal, subdorsal, and broad substigmatal lines with illy defined edges. Setæe coarse, black, with enlarged tips, alternating forward and backward; feet of joints 7 and 8 a little smaller.

The concluding stages remain to be described.

\section{ADMETOVIS OXYMORUS Grote.}

No specimens; one from Mr. Cockle's collection, June 28, 1902 (Sandon). It is a male and has brown hind wings.

BARATHRA CURIALIS Smith.

One specimen, June 10. It has less yellow shading than a bred specimen from Randolph, Vermont, before me, but is the same species, I judge. Eggs were obtained from this single specimen, but proved sterile.

Egg. - Laid in a small patch. Flattened spheroidal, base moderately flattened; ribs about 48 , rather narrow, moderate, diminishing rapidly by alternation near vertex, ending on the summit, the vertex in a broad, circular, radiate area; micropyle with a circle of py riform cells; cross-striæ very obscure, forming nearly quadrangular cells. Waxy yellow; diameter, $0.6 \mathrm{~mm}$; height, $0.5 \mathrm{~mm}$. 


\section{DARGIDA PROCINCTA Grote.}

Twenty-five specimens, May 31, June 13, 21, 23, 25, 27, July 14, August 6, 7, 13, September 8 (Glacier).

Egg.-Two-thirds spherical, the base flat; ribs about 40, diminishing irregularly at vertex, coarsely projected at apex, covered by reticulations, the longitudinal lines in the hollows and on the apices of the ribs forming rounded hexagonal cells which indent the sides of the ribs. An irregularly sculptured area about the raised micropyle, which has a circle of pyriform cells. Pale yellow; diameter, $0.6 \mathrm{~mm}$.

Stage I.-Head bilobed, clypeus high, brown-black, shining. Body stout, joint 12 slightly enlarged, feet of joints 7 and 8 short; cervical shield large, brownish. All sordid gray, whitish, with skin finely dark granular; alimentary canal reddish. Tubercles rather large, smoky; setæ black with swollen tips, normal, ia to iib of thorax separate, no subprimaries, iv above the center of the spiracle on the posterior segments; four stout sharp setæ at anus, two above and two below.

Stage II.-Head rounded, bilobed, shining sordid luteous, thickly dotted reticulate with blackish, except on median suture and line on each lobe; width, $0.55 \mathrm{~mm}$. Body moderate, tapered behind, joint 12 not enlarged; feet practically equal, the thoracic ones small. Blackish olivaceous green; dorsal, subdorsal, and lateral narrow pale lines, substigmatal line broader and white. Feet sordid, shields concolorous; tubercles and setæ obsolete. With growth, pale green, the lines obscure.

Stage III.-Head rounded, green, thickly marked with angular gray spots; width $1 \mathrm{~mm}$. Body normal, smaller behind, joint 12 scarcely enlarged. Velvety dark olivaceous with narrow pale-green lines; dorsal line isolated, subdorsal and three lateral lines closely approximated, the middle one diffuse; substigmatal band broader, greenish white. Feet pale; spiracles white; no shield, the lines reaching the ends; tubercles and setæ invisible.

Stage IV.-Head rounded, the apex in joint 2, greenish luteous, thickly brown dotted, lost in a sordid vertical shade; width $1.9 \mathrm{~mm}$. Dorsum olivaceous velvety black; sides lighter, obscurely traversed by four still lighter lines, the upper and lower of these the brightest; a dark area above the stigmatal band which is olivaceous, yellow dotted, diffuse below; subventer dark olivaceous, venter lighter; feet dotted.

Stage V.-Head heavily reticulated in leaden blackish and overspread with leaden; width $2.6 \mathrm{~mm}$. Body varies from light to dark. Ground color velvety olivaceous black; subdorsal and lateral bands. lighter, straight, rather broad, light-edged and darker filled; substigmatal band about the same, a shade lighter Subventer pulverulently black above, greenish below. Feet pale, the thoracic ones smoky; 
spiracles white; venter green; no shields. The light forms show only the dorsal space and suprastigmatal band dark, the rest all greenish.

Stage VI.-Head $3.5 \mathrm{~mm}$. I have described this stage previously from Californian larvæ. ${ }^{a}$ It is essentially like stage $\mathrm{v}$.

\section{XYLOMIGES PERLUBENS Grote.}

Four specimens, April 26 (Mr. Cockle), May 30, June 4, 6. XYLOMIGES RUBRICA Harvey.

No specimens; one from Mr. Cockle's collection, May 8. XYLOMIGES HIEMALIS Grote.

Two specimens, April 23 (Mr. Cockle), 26 (Mr. Cockle), and one from Mr. Cockle's collection April 17.

\section{XYLOMIGES SIMPLEX Walker.}

Two specimens, May 30.

\section{XYLOMIGES DOLOSA Grote.}

No specimens; one in Mr. Cockle's collection.

\section{SCOTOGRAMMA DENSA Smith}

No specimens. I refer with hesitation to this species, a single female from Mr. Cockle's collection, taken July 31. It is of a dark gray, produced by white powdering on a bluish black ground and patches of ocherous yellowish, most distinct in a line at base of fringe. It has a very different look to the types of densa and is doubtless worthy of a new name; but from the single specimen I do not care to characterize it.

\section{SCOTOGRAMMA UNIFORMIS Smith.}

Two specimens, July 29 (Bear Lake Mountain) and one in Mr. Cockle's collection, August 8, 1902 (McGuigan). Mr. Cockle's specimen is a female, more distinctly marked than the males, and approaches infuscata Smith, which is probably not specifically distinct from this.

\section{SCOTOGRAMMA SEDILIS Smith.}

Five specimens, June 26, July 24, 29 (Bear Lake Mountain), August 13 (Sandon, Mr. Currie). A female agrees well with the type of seditis Smith; the rest, a male and three females are not different from what I have as perplexa Smith. I have not the type of the latter, so do not make this synonymy at present. A specimen in Mr. Cockle's collec- 
tion is named inconcinna Smith, but it does not agree with the type before me. Professor Smith has made this same erroneous determination for the U. S. National Museum, and I suppose that he has conceived a wrong idea of his own species, not having the type before him.

ANARTA MELANOPA Thunberg.

Eight specimens, July 29 (Bear Lake Mountain). The hind wings are largely black at base, reducing the size of the white space, while the forewings are dark. I judge the form is not so extreme as laerta Smith, but probably connects it with melanopa. Kelloggi Hy. Edwards seems to be the same as or very close to the Kaslo specimens.

ANARTA LAPPONICA Thunberg.

One specimen, August 10 (Kokanee Mountain).

ANARTA ZETTERSTEDTI Staudinger.

One specimen, August 10 (Kokanee Mountain). It has the forewings very dark, the markings nearly lost; hind wings with the white space much reduced and powdered with black.

\section{TAPINOSTOLA ORIENTALIS Grote.}

No specimen; one in Mr. Cockle's collection.

\section{HELIOPHILA OXYGALE Grote.}

One hundred and seventy-two specimens, June 25, July 14, 21, 30, 31, August 5, 6, 7, 11, 12. The form occurring at Kaslo is marked like oxygale from California, but runs smaller, about the size of minorata Smith. Most of the specimens are lightly marked, some few run to heavy dark shadings (var. minorata Smith). I am satisfied, from a couple of slides made of the male genitalia, that there is easily enough variation to account for the slight differences between Smith's figures of oxygale and minorata, ${ }^{a}$ and therefore the name minorata expresses only a varietal form of oxygale, not a racial one. The species is the western form of the eastern luteopallens Smith, and both are only geographical expressions of the European pallens Linnæus, scarcely worthy of more than racial distinction. Eggs were obtained, but the larvæ persisted in hibernating and could not be carried to maturity.

Egg.-Elliptical, higher than wide, rounded barrel shaped; smooth, shining, pale yellow, with no trace of ribs; reticulations linear, irregularly quadrangular, the vertical lines mostly straight, faint, scarcely raised, smaller, and rounded on the vertex to the micropylar rosette. Diameter, $0.6 \mathrm{~mm}$; height, $0.7 \mathrm{~mm}$. 
Stage I.-Head slightly bilobed, rounded, brown; cervical shield brown. Body moderate, feet of joints 7 and 8 a little smaller, joint 12 scarcely enlarged. White, the skin dark, spicular; tubercles small, brown; setæ pointed; feet and leg plates smoky; chin gland clear, conical.

Stage II.-Head bilobed, oblique, brown, smoky shaded, eye black; width, $0.5 \mathrm{~mm}$. Body with joints $5-6$ and 12 slightly enlarged, feet nearly equal. Pale whitish with faint brown shadings, not defined; tubercles minute, dusky; setæ pale.

Stage III.-Head bilobed, brown, dark dotted by the tubercles; width, $0.8 \mathrm{~mm}$. Body rather slender and tapering a little to the ends, subequal. Translucent yellowish sordid green from the food; dorsal, subdorsal, lateral, and broad substigmatal lines whitish, sharply edged, but obscure, a slight brown shading between them; tubercles small, black.

Stage IV.-Head pale luteous, darkly reticulate, tubercles black, a black shade before vertex of lobe within; width, $1.2 \mathrm{~mm}$. Body moderate, equal, of a translucent reddish brown; dorsal line narrow, whitish, a broad smoky area around tubercle i; subdorsal and lateral lines whitish, not edged, the space between lateral and substigmatal lines smoky blackish on the edges, brown centrally. Substigmatal band whitish, not contrasted; subventer faintly brown tinged. Tubercles small, black, contrasted; cervical shield shining, concolorous with the markings before, but luteous behind; feet pale.

At this point the larvæ became persistent in their efforts to hibernate, but a stage was obtained with head of $1.4 \mathrm{~mm}$. on September 18, and another of $1.7 \mathrm{~mm}$. on October 7, but they did not differ in markings and are not improbably interpolated. The last stages remain to be observed.

\section{HELIOPHILA ROSEOLA Smith.}

One hundred and thirty-four specimens, June 3C, July 2, 8, 19, 24, 27, 31, August 4, 5, 6. It varies in the depth of the reddish tint of the fore wings, but this is never wholly lacking. The transverseposterior line sometimes appears as a row of five dots, but two is the usual number, and they may be wholly wanting. The species approaches calgariana Smith. Some of the darkest forms apparently come out as that species in Smith's synoptic table on account of the presence of a faint darker shade under the median vein; but on comparison with the types of calgariana the roseola are all far less brightly marked and can not be confused with it. It is closely allied to and perhaps only a race of farcta Grote, which lacks the red tint. The larva is like farcta, with the markings brighter and more contrasted. It fed on grass.

Egg.-Laid crowded in the groove of a leaf, gummed into a mass. 
Nearly spherical, the base a little flattened; perfectly smooth, shining yellowish white without sculpture; diameter, $0.6 \mathrm{~mm}$.

Stage I.-Head slightly bilobed, round, brownish luteous, ocelli black. Body short, robust, joint 12 and the central segments slightly enlarged. Cervical shield large, pale luteous. Body whitish, densely clear granular; tubercles minute, brown; setæ moderate, pointed, colorless. Feet of joint 7 very slightly shorter than the others. Later the food appears green.

Stage II.-Head pale luteous, vertex narrowly blackish; width $0.55 \mathrm{~mm}$. Body thickened at joints 5-6, joint 12 enlarged. Yellowish, green from the food, especially in joints 5 and 6 . Dorsal, subdorsal, traces of lateral and broad stigmatal bands faint, white. Cervical shield a little blackish, but not cornified. Tubercles and setæ obscure.

Stage III. - Head pale luteous with traces of brown vertical lines; a dark shade behind vertex; width, $1.05 \mathrm{~mm}$. Body moderate, joints 5-6 and 12 a trace enlarged. Olive green, lines white, straight; dorsal, trace of upper subdorsal, lower subdorsal, lateral, a line between lateral and substigmatal, brown shaded; trace of suprastigmatal; substigmatal broad, yellowish tinted, folded. Feet brownish marked; no shields; tubercles and setæ obscure.

Stage IV.-Head rounded, full, whitish with rather open brown reticulations and vertical bands; width, $1.5 \mathrm{~mm}$. Body moderate, equal, feet nearly equal. Straw-yellow; dorsal, upper and lower subdorsal and lateral lines whitish, even, brownish edged, obscure; space below lateral line gray brown, divided by a dilution. Substigmatal line white, straw-yellow filled. Feet pale with dusky tubercles; tubercles small, black; setæ short, obscure.

Stage V.-Head round, whitish luteous, reticulations open, faint with faint vertical bands, shining; width, $2.3 \mathrm{~mm}$. Body equal; straw-yellow; dorsal, upper and lower subdorsal and lateral lines straight, whitish, distinct, edged by light brown; three lines alternating with them narrow and waved; lateral space dark brown, filled with a narrow central pale line; a white line at the top of the black spiracles; substigmatal band broadly straw-yellow filled, its lower edge also white; subventer dully marbled. Tubercles small black. Feet dark shaded; setæ minute; no shields.

Stage VI.-Head large, rounded, shining pale luteous with smokybrown reticulations and vertical bands; width, $3.2 \mathrm{~mm}$. Body moderate, equal, no shields, uniformly colored. Light straw yellow; dorsal space blackish reticular, defining a white dorsal line and addorsal dilution; a black, distinct, even subdorsal band, lightened centrally by a double straw-brown line; suprastigmatal space heavily and distinctly black reticulate on a whitish ground, forming a black band like the subdorsal one, diluted centrally. Substigmatal band white edged, straw-brown filled. Feet nearly white, those of joints 7 to 10 , with 
curved black bars outwardly, the others entirely pale, the anal pair with gray reticulations. Tubercles small, i showing blackish; setæ fine, obscure.

HELIOPHILA COMMOIDES Guenée.

Two specimens, July 2.

\section{HELIOPHILA HETERODOXA Smith.}

Five specimens, May 29, June 1, 4, 11. The basal streak on fore wings may be faint (heterodoxa Smith) or distinct (megadia Smith). There is obviously no specific difference between these forms. The species is close to insueta Guenée and apparently only a geographical expression of it; yet, being lighter and slighter than its eastern ally, it violates the usual rule for western races, and I would not, therefore, unite these forms specifically.

Eggs were obtained from captive females in good season; the larvæ were fed on grass.

Egg.-Laid crowded into crevices of the leaf and glued together. Two-thirds spherical, the base well flattened, smooth, no trace of ribs; surface neatly reticulate in linear, mostly quadrangular lines, slightly elongate vertically. Pale yellow; diameter, $0.7 \mathrm{~mm}$.

Stage I.-Head rounded, testaceous, the edges, sutures, and mouth brown; width, $0.4 \mathrm{~mm}$. Body robust, normal, joint 12 a little enlarged, feet all present, the anterior abdominal ones a little smaller. Whitish, unmarked; cervical shield small, brown. Tubercles minute, black, iv above the spiracular line; foot plates and anal plate dusky; setæ moderate, long. Later the food appears dark green in spots; faint brown subdorsal and lateral lines.

Stage II.-Head round, shining whitish, broadly shaded with brown; ocelli black; width, $0.5 \mathrm{~mm}$. Body enlarged at joints 4-6, slender behind, 12 a little enlarged. Whitish, green shaded; dorsal, subdorsal, and lateral lines white, straight, obscure. Substigmatal line broad, white, the space between it and lateral line filled in with brown shading; a subventral brown shaded band. Tubercles small, black; setæ short, pale; feet, smoky shaded; no shields.

Stage III.-Head very pale brown with dark reticulations on the back part; eyes black; width, $0.8 \mathrm{~mm}$. Body moderate, largest before, tapering behind, joint 12 slightly enlarged dorsally. Very pale fleshy whitish; dorsal, subdorsal, and lateral lines whitish, narrow, straight, obscurely dark-edged; substigmatal band broad, white, edged above and below by a broad dark-brown band, the upper one the most distinct mark on the body. Feet nearly equal, all pale; tubercles and setæ obsolete.

Stage IV.-Head round, full, about spherical, free, oblique, shining pale luteous, faintly reticulate, most strongly so on the vertices and 
sides of the lobes, ocelli black; width, $1.2 \mathrm{~mm}$. Body slender, tapering a little, joint 12 slightly enlarged dorsally. Smooth translucent green, the color mostly from the food; dorsal, upper and lower subdorsal and lateral lines white, about as broad as the spaces; stigmatal band white. Between it and the lateral line, all dark purplish brown; subventer irregularly shaded in brown. Folded bases of the feet whitish; feet colorless; tubercles minute, black; setæ short, pale.

Stage V.-Head round, slightly bilobed, full, large, shining waxy white, faintly reticulate in brown; width, $1.8 \mathrm{~mm}$. Body moderate, equal; feet equal. Pale brown, mottled with dark brown; dorsal line narrow, white, subdorsal broad, eroded geminate above; lateral straight, a trace of a line below it; lower lateral straight; between this and the stigmatal line a broad dark-brown area obscurely geminate by a dilution. Stigmatal band white, below the spiracles on joints 2 and 12 ; subventer slightly brown mottled. Feet whitish; tubercles dark, but obscure; no shields.

Stage VI. - Head luteous white, reticulate with brown and with vertical bands beside the cly peus and a narrow one from eye; width, $2.5 \mathrm{~mm}$. Body finely and neatly striped. Ground color pale creamy; dorsal line white, broadly dark brown edged, powdery without with a partly detached line along tubercle i. Subdorsal line white, powdery, dark brown edged above; lateral line white, straight like the others; lateral space brown filled, with a central dilution, almost forming a line. Space between lateral and stigmatal purple-brown filled, with a similar linear dilution, whitish. Substigmatal band white, geminate by a broad waved filling. Subventral area luteous, white dotted. Feet pale; tubercles $\mathrm{i}$ and ii with small black spots, the other tubercles concolorous; spiracles black; shields concolorous. The body is uniform, joint 12 not enlarged; feet equal; setæ short, obscure.

Stage VII. - Head luteous, reticulations and vertical bands dark brown; width, $3.5 \mathrm{~mm}$. Body equal, tapered a little at the ends; luteous, white dotted, brown reticulate. Dorsal line white, dark edged; subdorsal and lateral similar, the subdorsal broadly dark above. Space between lateral line and spiracles dark; substigmatal band white; luteous filled; subventer white dotted; feet pale.

\section{ZOSTEROPODA HIRTIPES Grote.}

Forty-two specimens, June 16, 19, 23, 25, July 8, 21, 27, 30, August 11.

Egg.-Low ellipsoidal, the base flattened; ribs about 36, broad, low, indistinct, covered by reticulations, the apical ones on the ribs forming a regular zigzag; no lines in the hollows and the cross-striæ obsolete on the sides but distinct toward vertex, where there is a coarse, rounded, hexagonal reticulation, irregular and confused; micropylar circle of pyriform cells slightly raised. Pale yellow, with a reddish ring and spot; diameter, $0.8 \mathrm{~mm}$. 
Stage I.-Head rounded, slightly bilobed, clypeus high, whitish; three vertical rows of brown spots on each lobe; width, $0.3 \mathrm{~mm}$. Body moderate, normal, joint 12 slightly enlarged, feet of joints 7 and 8 small, whitish; the tubercles small, brown, shields concolrous with the body; no marks; feet pale; setæ rather long, sharp, normal, ia to iib separate.

Stage II.-Head long, rounded before, the apex in joint 2; whitish, a brown line from the eye, one parallel to suture and edging clypeus roundedly, and a row of dots approximate to the latter, ocelli black; width, $0.55 \mathrm{~mm}$. Body slender, joints 5 to 7 thicker and looped up a little, joint 12 scarcely enlarged, 10 and 11 narrower, feet of 7 and 8 smaller; whitish, green from the food; dorsal, subdorsal, faint lateral, broad substigmatal lines whitish; sides shaded in brown between the subdorsal and stigmatal lines. Tubercles small, dark; feet pale.

Stage III.-Head elongate, narrowed to the mouth, held flatly, white, with rows of purple-brown dots edging the suture on face and on angle of lobes; clypeus tlark edged, jaws dark, vertex of lobes smoky behind; width, $0.8 \mathrm{~mm}$. Body slender, elongate, slightly flattened, feet of joint 7 very small, those of joint 8 larger; whitish, shaded with ocherous; dorsal line white, dull olive edged, tubercle $\mathrm{i}$ in a large, olive spot; ii in a smaller one; subdorsal line white, straight, traces of a lateral line, the sides dark brown filled. Substigmatal line white, showing on subventral fold, partly concealed subventrally and brownish filled. Feet pale, with spots on the tubercles.

Stage IV.-Head held flatly, white with vertical dotted lines, two on the lobe parallel to suture, one on side of head, marbled and a streak from the eye, brown black; width, $1.1 \mathrm{~mm}$. Body large for the head, largest at joints 5 and 6 , tapering each way, joint 12 again a little enlarged. Fleshy whitish, tubercles small, black; lines on dorsum whitish, obscure, hardly traceable, defined by grayish cloudings; sides darker, with two whitish lateral lines; stigmatal band white, bisected by luteous gray; feet pale.

Stage V.-Head round, oblique, white, marked as before; width, $1.5 \mathrm{~mm}$. Body slender and flattened, anal feet extended backward, clasping. Fleshy brown, dorsal space yellowish brown, marbled between the narrow, obscure dorsal and subdorsal lines. Tubercles small, black; sides dark, shaded in broad, diffuse longitudinal bandings; substigmatal band white, geminate by a brown filling; subventral area marbled in brown; feet pale with black tubercles; setæ small.

Stage VI.-Head held flat, the apex in joint 2, straw yellow, luteous brown reticulate, the vertical bands no longer separate; width, 2.1 $\mathrm{mm}$. Body flattened, the sides projecting, narrowed slightly toward the ends, feet equal, no shields; straw brown, dotted with black without distinct lines. The black dots are segregated about the obsolete dorsal and subdorsal lines and over the tubereles, especially on joints 11 and 12 where a contrasted shade is produced. Sides shaded in 
dark brown, obscurely triplicate, including the obsolete lateral line; substigmatal band all red-brown marbled, its edges clearer yellowish white; subventer dark brown dotted on the upper half, reddish below and on venter. Feet pale with black tubercles; dorsal tubercles white; setæ fine, rather short.

HIMELLA INFIDELIS Dyar.

Four specimens, July 2, 19, 21 (Bear Lake) and one from $\mathrm{Mr}$. Cockle's collection, July 12, 1902.

\section{GRAPHIPHORA CURTICA Smith.}

Thirteen specimens, August 16,17, 18, all very dark in color but apparently conspecific with curtica, described from the Sierra Nevada of California. I have others from Pullman, Washington (C. V. Piper).

\section{GRAPHIPHORA COMMUNIS Dyar.}

Three thousand four hundred and twenty-five specimens, June 13, 16, 19, 25, July 2, 24, 25, 27, 30, August 4, 5, 6, 7, 11, 12, 13, 15, 16, 17, 18. This is the species described by Smith as Taeniocampa furfurata Grote, ${ }^{a}$ but it is not Grote's furfurata, which has scaly vestiture. I therefore proposed the name communis for this form. Smith's locality "New York" is erroneous, as is also the locality "Illinois." The single female before me, on which he made the latter reference, differs from communis in the straighter, more uniform and oblique transverse anterior line, both this line and the transverse posterior distinctly pale filled. I think it is at least a different race from communis and I would call it smithii.

Type.-Cat. No. 7334, U.S. National Museum.

The first brood of communis is grayer and smoother than the second which is more yellowish brown and contrasted.

Egg.-Spheroidal, the base flattened, upper half more rounded; ribs moderate, diminishing in pairs; reticulations also moderate, cresting the ribs and forming cross-striæ; apex reticulate, micropyle with circle of pyriform cells. Pale yellow; diameter, $0.7 \mathrm{~mm}$. Laid singly, adherent.

Stage I.-Head bilobed, pale luteous, with dusky spots on the tubercles. Body moderate, normal, feet of joint 7 very small, of 8 larger, the others normal. Whitish, smooth, green from the food; tubercles moderate, dusky; setæ long, pale with small bulbous tibs; tubercle iv above the center of the spiracle.

Stage II.-Head rounded, pale sordid luteous, thickly fleckled with dark over the lobes and in vertex; width, $0.55 \mathrm{~mm}$. Body short, robust, narrower behind, joint 12 enlarged, the feet of 7 smaller than 
the others. Fleshy, brownish; darker shaded on the sides, faintly indicating a greenish subdorsal line. Cervical shield and tubercles brownish, hair dots black; setæ moderate, dark.

Stage III.-Head pale whitish, a smoky shade at vertex, thickly dotted with black over lobes and in median suture; width, $0.8 \mathrm{~mm}$. Body short, robust, dark brown shaded, with narrow yellowish broken dorsal and subdorsal lines. Cervical shield luteous, edged and spotted with blackish. Upper edge of stigmatal band indicated, below it paler. Tubercles moderate, black; setæ rather long, glandular tipped; feet nearly equal, with darker shields.

Stage IV.-Head pale brown, thickly spotted with round black dots in median suture and over lobes; width, $1.2 \mathrm{~mm}$. Body robust, thorax tapering to the head, joint 12 enlarged. Pale brown, mottled and speckled with blackish; dorsal line narrow, whitish, smoky edged. Oblique whitish shades from posteriorly near dorsal line to subdorsal anteriorly on the segments, dark margined before, define obscure diamond-shaped dorsal patches, olivaceous shaded. Tubercles round, black; setæ short, pale; cervical shield pale, irregularly black powdered, leaving pale dorsal and subdorsal lines.

Stage V.-Head with the apex in joint 2, sordid luteous with thick, round black spots except on the face and a band on the lobe; width, $1.8 \mathrm{~mm}$. Body robust, somewhat flattened, joint 12 slightly enlarged. Blackish gray, thickly black streaked and white dotted on a pale brown ground; shield concolorous. Oblique light subdorsal lines posterior and dorsal, forward and downward on joints 5 to 12 , bar-shaped on joint 12, darker shaded behind. Substigmatal band paler, reddish reticulate, shading to the subventer, all white dotted. Traces of a pale dorsal line.

Most of the larvæ had but five stages, though one was noted with a $1.4 \mathrm{~mm}$. head, which would indicate six stages in that specimen.

GRAPHIPHORA UNIFORMIS Smith.

Eight specimens, July 19, August 12.

GRAPHIPHORA ALIA Guenée.

No specimens; one from Mr. Cockle's collection, April 18.

STRETCHIA NORMALIS Grote.

No specimens; one from Mr. Cockle's collection, April 23.

STRETCHIA PLUSIIFORMIS Hy. Edwards.

No specimens; one in Mr. Cockle's collection, September 27. I have described the larva from Coloradan specimens. ${ }^{a}$ 


\section{STRETCHIA VARIABILIS Smith.}

No specimens• one in Mr. Cockle's collection, April 28, 1902. PERIGRAPHA ACHSHA Dyar.

No specimens; one from Mr. Cockle's collection, April 24. CLEOCERIS RECTIFASCIA Smith.

Five specimens, July 31, August 1, 11, 13, 16. The species was described from the mountains of California. One of the specimens has the light tint in the reniform pale yellow instead of the usual brownish red.

\section{PLEROMA OBLIQUATA Smith.}

No specimens; one from Mr. Cockle's collection, April 26.

\section{PLEROMA BONUSCULA Smith.}

No specimens; one in Mr. Cockle's collection taken August 24, I refer here. It differs from the type in the blackish shadings being reduced, while the double row of black spots separated by the fragments of the white subterminal line is prominent, the spots slightly produced, suggesting dashes. The specimen is a little rubbed. A series might show a form worthy of a distinctive name.

\section{XYLINA FAGINA Morrison.}

No specimens; one in Mr. Cockle's collection, April 24.

\section{XYLINA OREGONENSIS Harvey.}

No specimens; one from Mr. Cockle's collection apparently represents a stray specimen from the coast region.

XYLINA CAPAX Grote and Robinson.

No specimens; one in Mr. Cockle's collection, September 20.

\section{EUHARVEYA CARBONARIA Harvey.}

No specimens; one from Mr. Cockle's collection, April 23.

\section{LITHOLOMIA NAPÆA Morrison.}

Four specimens, May 30, June 2.

CALOCAMPA CINERITIA Grote.

No specimens; one in Mr. Cockle's collection, May 14, 1901. 
CUCULLIA OBSCURIOR Smi.h.

One specimen, August 4.

CUCULlia POSTERA Guenée.

Two specimens, July 8, August 20 (Nelson).

GORTYNA MEDIALIS Smith.

No specimens; one in Mr. Cockle's collection.

PYRRHIA EXPRIMENS Walker.

No specimens; one in Mr. Cockle's collection, July 20, 1901.

XANTHIA FLAVAGO Fabricius.

Two specimens, August 15, 17.

TRIGONOPHORA PERICULOSA Guenée.

Two hundred and sixty specimens, July 14, 21, 22, 27, August 3, $4,5,6,15,17$. Variable within the usual specific range. The form $v$-brunneum occurred in small proportion. Eggs were obtained, but only a few larvæ reached the last stage before winter.

Egg.-Nearly spheroidal, the top slightly conoidal, roughened by the ends of the ribs, base flattened moderately; ribs about 32 around the margin, diminishing above by alternation to 10 about the vertex, where they end in a low ring formed by a prominent cross-stria; within this a series of low radiate bars to the micropylar rosette which is elevated; cross-striæ low, rounded, yet distinct, the cell areas gently concave, twice as wide as high or more. Surface subgranular shagreened; pale yellow later with a brown ring and spot; diameter 1 mm. Laid singly.

Stage I.-Head round, bilobed, pale brown with smoky black spots on the tubercles, mouth red brown. Body moderately elongated, semilooping, feet of joints 7 and 8 small, joint 12 enlarged. Cervical shield pale brown; leg shields not infuscated, white; the tubercles large, black; setæ black, stiff, pointed.

Stage II.-Head bilobed, oblique, pale luteous with distinct black spots on the tubercles; width, $0.8 \mathrm{~mm}$. Body rather slender, flattened, joint 12 enlarged laterally, feet of 7 and 8 small. Clear translucent green without shields; a broad, waved, obscurely geminate subdorsal line dividing the dorsal space into diamond-shaped green marks; a broad suprastigmatal more blackish band; subventral region more whitish. Tubercles round, black, distinct; setæ black, pointed.

Stage III.-Head bilobed, oblique, green, brownish on the vertex, the tubercles black; width, $1.1 \mathrm{~mm}$. Body soft clear green, the seg- 
ments submoniliform, joint 12 the most enlarged, feet of joints 7 and 8 smaller. White dorsal intersegmental spots, double on the posterior edges of the segments, single and fainter on the anterior edges; olivaceous blackish broad open shadings, inclosing traces of the white subdorsal line and extending on the dorsum and sides, forming a broad, straight band over tubercle iii to the substigmatal band, which is broad, pale green, and shading to the subventer. Tubercles round, black; setæ small; no shields.

Stage IV.-Head as before shining with pale brown reticulations and black spots on the tubercles; width, $1.5 \mathrm{~mm}$. Body olivaceous green, marked as before in brown linings. The broad substigmatal band and subventer are distinctly whitish.

Stage V.-Head rounded bilobed, pale brown with dark brown reticulations and brown vertical bands; width, $2.1 \mathrm{~mm}$. Body moderate, joint 12 gently enlarged, the incisures somewhat marked. Light olivaceous green, dotted and streaked in dark rad brown, forming edges to the dorsal line, tubercles $\mathrm{i}$ and ii and long oblique streaks to the dark edge of the substigmatal line. Dorsal line resolved into two rounded spots to each segment and an anterior faint streak; tubercles i and ii whitish; substigmatal band rather narrow, white, the subventer sparingly brown marked. Feet brown marked; spiracles black; tubercle iv above the middle on the posterior segments.

Stage VI.-Head pale greenish luteous, reticulations and bands light brown; tubercles $\mathrm{i}$ and ii black marked; width, $2.8 \mathrm{~mm}$. Body soft light olivaceous yellowish, robust, the segments enlarged, all nearly equal. It is flecked with patches of light brown, edging the dorsal line, tubercles $\mathrm{i}$ and ii, forming oblique side lines and edging the substigmatal band above. Dorsal line forming two dots posteriorly on the segments, rounded, white; tubercles $\mathrm{i}$ and ii white; spiracles black edged; substigmatal line obsolete, light, nearly without markings; subventer red marked instead of brown; thoracic feet brownish; tubercles distinct, white, setæ moderate.

One larva spun a slight cocoon of white silk October 28.

EUCIRREDIA PAMPINA Guenée.

Four specimens, August 18.

SCOLIOPTERYX LIBATRIX Linnæus.

Six specimens, May 29, 30, June 13, 25. The characteristic larva was found on willow.

PSEUDORTHOSIA VARIABILIS Grote.

Eighty-six specimens, August 6, 11, 13, 16, 17. 


\section{COSMIA PALEACEA Esper.}

Sixteen specimens, July 7 (bred), 30, 31 (bred), August 4, 6, 7, 13, 18. Of these eight have the spot in the reniform like European paleacea; the others lack it (var. discolor Walker). The larva was found on birch and aspen.

Stage VI.-Head bilobed, free, shining pale yellow, ocelli partly brown; width, $3.5 \mathrm{~mm}$. Body moderate, joint 12 scarcely enlarged. Translucent frosted whitish, food showing green. Dorsal line white, narrow, straight; subdorsal less rigid and narrower, two stigmatal lines, one above and one below the spiracle, linear, waved like the subdorsal. Feet pale, no shields, tubercles small, white, iv above the center of the spiracle posteriorly. The skin is perfectly transparent, the whitish frosted look being subcutaneous and caused largely by the branches of the tracheæ, both those running to the skin and to the stomach being separately visible. Spiracles white, brown ringed.

\section{ORTHOSIA PURPUREA Grote.}

Three specimens, September 8 (bred), 10 (bred), and four from Mr. Cockle's collection, September 18, 19, 20. Larvæ were found on hollyhock and plantain.

Stage V.-Joint 12 slightly enlarged; green, dorsal, subdorsal, and broad substigmatal bands white, the subdorsal waved; body all white dotted; tubercles small, white; spiracles white, black ringed.

Stage VI.-Head rounded, apex in joint 2, erect, very pale brown, mottled reticulate in darker gray, forming faint broad bands on the faces of lobes. Body cylindrical, normal, joint 12 scarcely enlarged. Cervical shield black with a few pale dots, cut by a whitish subdorsal line, weakly cornified. Body light brown, minutely dotted with whitish; a series of subdorsal black marks on joints 5 to 12 , diamondshaped and throwing an arm from the lateral angles anteriorly, lighter centrally, cut by the narrow, broken, powdery white dorsal line. Tubercles $\mathrm{i}$ and ii small, white. Traces of a pale subdorsal line, black edged; substigmatal line broad, filled by mottlings of the brown ground till only its edges show white, dotted like all the ground and especially the subventral region. Tubercles iii to vi white, not as contrasted as tubercles $\mathrm{i}$ and ii. Feet all pale.

ORTHOSIA BICOLORAGO Guenee, var. FERRUGINOIDES Guenée.

Eight specimens, August 12, 17, 18, and two ‘from Mr. Cockle's collection August 24 and September 19.

\section{ORTHOSIA EUROA Grote and Robinson.}

One specimen, August 22 (Revelstoke) and one from Mr. Cockle's collection August 20.

Proc. N. M. vol. xxvii $-03-60$ 
IPIMORPHA PLEONECTUSA Grote.

Six specimens, July 3 (bred), August 7, 12, 18. Both the dark normal form and the light clay-colored one (var. xquilinea Smith) occurred. Larvæ were found separately in neat houses of leaves with a round hole at the lower end, on aspen.

Stage VI.-Head rounded, disk like, yellowish white, white on the face, which is edged by a semicircular heavy black band; jaws and sutures of mouth black; width, about $3 \mathrm{~mm}$. Body normal, flattened ventrally, joint 12 not enlarged. Translucent, green from food and blood, a broad, dorsal pale white band on joints 3 to 13, narrowed before; cervical shield all green, not cornified; a similar but narrower and broken subdorsal line; a narrow substigmatal white line, resembling the tracheal line. Thoracic feet black tipped; abdominal ones normal. Tubercles small, pale, white with dark hair dots, iv at the lower corner of the spiracle; spiracles white, black edged; skin shagreened.

HELIOTHIS PHLOGOPHAGUS Grote and Robinson.

No specimens; one in Mr. Cockle's collection. I have described the larva from Coloradan specimens. ${ }^{a}$

HELIOTHIS SCUTOSUS Fabricius.

No specimens; one in Mr. Cockle's collection.

MELICLEPTRIA HONESTA Grote.

No specimens; Smith's type of Melicleptria kasloa is, however, before me and seems inseparable from honesta Grote.

MELICLEPTRIA SEPTENTRIONALIS Hy. Edwards.

No specimens; one from Mr. Cockle's collection, June 7 (Ainsworth). HELIACA NEXILIS Morrison.

Three specimens, July 21 (Bear Lake Mountain), 29 (Bear Lake Mountain).

PLUSIA AEREOIDES Grote.

No specimens; one from Mr. Cockle's collection, August 19, 1902.

PLUSIA METALLICA Grote.

Two specimens, August 6, 11.

AUTOGRAPHA MAPPA Grote and Robinson.

Two specimens, August 13 (Sandon, Mr. Currie). 
AUTOGRAPHA FLAGELLUM Walker.

No specimens; one in Mr. Cockle's collection, August 12.

AUTOGRAPHA PSEUDOGAMMA Grote.

One specimen, July 25.

AUTOGRAPHA CALIFORNICA Speyer.

Twenty-three specimens, June 1, 6, 7, 11, 13, 16, July 1 (bred), 3 (bred), 4, 24, 31, August 2, 3, 4, 5, 6, 24 (Vancouver). Eggs were obtained from captive females and the larvæ throve well, completing in five stages. I have elsewhere described the stages, ${ }^{a}$ and will therefore not repeat the descriptions.

AUTOGRAPHA BRASSIC $Æ$ Riley.

Three specimens, June (Mr. Cockle), August 25 (bred). No description was taken of this well-known larva.

AUTOGRAPHA RECTANGULA Kirby.

Six specimens, July 26, August 3, 4, 6, 7 .

AUTOGRAPHA U-AUREUM Guenée.

Four specimens, August 18, 20 (Nelson), and one given me by Mr. Cockle.

AUTOGRAPHA VACCINII Hy. Edwards.

One specimen, August 4.

AUTOGRAPHA SELECTA Walker.

Two specimens, August 6, 15 .

AUTOGRAPHA EPIGAEA Grote.

No specimens; one in Mr. Cockle's collection, August 26, 1902.

AUTOGRAPHA AMPLA Walker.

Two specimens, July 15, August 13 (Sandon, Mr. Currie).

AUTOGRAPHA DIASEMA Boisduval.

One specimen, September 8 (Glacier, dead in an electric light).

SYNGRAPHA IGNEA Grote.

One specimen, September 8 (Glacier, dead in an electric light). 
MARASMALUS INFICITA Walker.

No specimens; one in Mr. Cockle's collection.

\section{ANNAPHILA DANISTICA Grote.}

No specimens; one in Mr. Cockle's collection.

EUSTROTIA ALBIDULA Guenée.

Eighteen snecimens, July 11 (Fletcher's Ranch), August 23 (Mission Junction). 'This species did not occur at Kaslo at all. At both places where I took it there are cultivated fields.

\section{THERASEA ANGUSTIPENNIS Grote.}

One specimen, August 10 (Kokanee Mountain, on snow).

\section{TARACHE MAJOR Smith.}

No specimens; one in Mr. Cockle's collection, August 1, 1902.

TARACHE ARELI Strecker.

Two specimens, June 23, July 23. Eggs were obtained from one of the specimens and the larvæ hatched, but I could not find their food plant.

Egg.-A little higher than wide, slightly conoidal, base rounded flattened; ribs about 40 at the side, diminishing by alternation to 10 at the edge of the micropylar area, straight, sharply elevated from a flat surface; cross-striæ obsolete, except at the ends of the ribs, vertex irregularly quadrangularly reticulate with a cluster of small cells at the micropyle. Bright bluish green; diameter, $0.75 \mathrm{~mm}$.

Stage I.-Head large and thick, rounded, black. Body slender, the segments moniliform, feet of joints 7 and 8 absent, the other feet large. Cervical shield and thoracic feet black; tubercles large, blackish, normal, no subprimaries; leg plates blackish. Luteous ochraceous, darkened by fine skin granules, the segments broadly, diffusely marked with dark vinous. Setæ black with small bulbous clear tips; joint 12 slightly enlarged.

\section{HYAMIA SEXPUNCATATA Grote.}

One specimen, June 8, and one from Mr. Cockle's collection, June 14. I have described this larva on dogbane from New Hampshire specimens. $^{a}$ 


\section{MYCTEROPHORA LONGIPALPATA Hulst.}

Nine specimens, July 15, 18, 19, 24, 27. The species was identified for Mr. Cockle by Prof. J. B. Smith, by comparison with Hulst's type. The genus, described as a Geometrid, is properly referable to the Noctuidæ. Prosoparia Grote is probably also a Noctuid genus, judging from Hulst's description of the venation. Eggs were obtained from captive females, but the little larvæ soon exhibited the inevitable tendency to hibernate, and only the first three stages were obtained. They fed on green lichens growing on damp wood.

Egg._Ellipsoidal, base slightly flattened, top granularly roughened; ribs about 40 , low, narrow, neatly waved, diminishing by confluence to 12 at the edge of the micropylar area; cross striæ distinct, rounded, the cell areas not much wider than high; the ribs run practically to the micropyle. Pale yellow, later with the top all reddish; diameter, $0.6 \mathrm{~mm}$.

Stage I.-Head round, bilobed, thick, held flatly; brown, smoky tinged. Body slender, elongate, joint 12 slightly enlarged, semilooping, the feet of joints 7 and 8 entirely absent. Whitish, the alimentary canal reddish. Tubercles rather large, brown, angular, normal; setæ very long, curved, white, smooth, with small bulbous tips. Cervical shield, leg-plates and anal plate blackish.

Stage II.-Head bilobed, pale whitish, sutures dark brown, a vertical line in clypeus and obscure dottings on the tubercles; width, 0.45 $\mathrm{mm}$. Body cylindrical, moderately elongate, no feet on joints 7 and 8 , those of 9 and 10 approximate. Pale whitish, with longitudinal crimson lines, shadedly joined centrally on the segments, subdorsal, lateral, supra- and substigmatal and subventral, irregularly broken. Feet pale; setæ long, curved, dusky; tubercles minute, dark.

Stage III.-Head broad, rounded, dull brown gray; width, $0.6 \mathrm{~mm}$. Body slender, elongate, feet of joints 7 and 8 absent. As before, but the color changed. Nearly uniform dull dark gray brown intersegmentally; on the segments with fine longitudinal streaks of yellowish white, addorsal, subdorsal, lateral, stigmatal, and subventral, rather irregular and not rigid. Venter pale between the feet. Hair soft, pale, long, curved. Tubercles slightly raised, concolorous; hair dots dark.

The subsequent stages were not obtained.

\section{EUCLIDIA CUSPIDEA Hübner.}

No specimens; one in Mr. Cockle's collection.

MELIPOTIS PALLESCENS Grote and Robinson.

No specimens; one in Mr. Cockle's collection, June 24, is a worn and faded specimen, originally darkly colored, but I think referable here. 
MELIPOTIS JUCUNDA Hübner.

No specimens; one in Mr. Cockle's collection, July 12, 1902.

CIRRHOBOLINA MEXICANA Behr.

No specimens; one in Mr. Cockle's collection, August 12, 1901.

SYNEDA ALLENI Grote.

Three specimens; May 30, June 6, 26.

SYNEDA SOCIA Behr.

No specimens; one in Mr. Cockle's collection.

SYNEDA OCHRACEA Behr.

No specimens; one in Mr. Cockle's collection, July 10 (Ainsworth). SYNEDA HUDSONICA Grote and Robinson.

Thirty-eight specimens; May 29, June 4, 6, 8 (Ainsworth), 9, 11, 18,29 , July 2, 13 . The specimens vary in the color of the middle band of fore wings from uniformly pale gray to a bright chestnut brown shading on the central part. This is the form seposita Hy. Edwards, which is not a distinct species as hitherto listed. I endeavored many times to obtain eggs of this species, but always without success.

CATOCALA BRISEIS Edwards.

Six specimens, August 12, 13, 16, 17, 18. They agree exactly with Eastern briseis, although I had expected them to be the Californian hermia Hy. Edwards. Two of them are of the form groteana Bailey.

CATOCALA AUGUSTA Hy. Edwards.

Two specimens, August 12, 15. The specimens agree with others which Mr. Beutenmüller has so named for me.

\section{CATOCALA RELICTA Walker.}

No specimens; one in Mr. Cockle's collection, which he has kindly transmitted to me for examination. It was supposed to represent elda Behrens, but if so, then I do not regard this as distinct from relicta.

\section{TOXOCAMPA VICTORIA Grote.}

Forty-two specimens, June 25, July 12, 14, 15, 25, 26, August 1. Eggs were readily obtained from captive females, but I could not feed the young larvæ. I judge that they do not have a particular food plant, as the eggs were laid loose and rolling about; perhaps they hibernate in stage $i$. 
Egg.-Perfectly spherical, rolling about in the dish like shot, very slightly adherent as laid, but not enough to stick to a leaf. About 26 vertical ribs, diminishing toward the ends, sharp, crested by the vertical reticulations, but low and with broadly concave spaces between, rather remote. Cross striæ fine, parallel, forming rectangular cells four times as wide as long. Sordid pale green; diameter, $0.9 \mathrm{~mm}$.

Stage I.-Head rounded bilobed, oval, whitish, a narrow curved mottled brown band on the face of each lobe, mouth brown. Body long, slender, vibrant looping, sordid whitish without marks. Feet of joints 7 and 8 very short; shields concolorous; tubercles small, brown, setæ moderate, pointed.

\section{HOMOPTERA CALYCANTHATA Smith and Abbot.}

Seven specimens, May 13 (Mr. Cockle), June 1, 2, 16, 19, 23. The moths occurred in two forms, with and without ocherous shading. Eggs were obtained from both and the resulting larvæ proved indistinguishable.

Egg.-Two-thirds spherical, the base flattened, rounded under. About 40 ribs, narrow, moderate, waved, with faint obsolete cross striæ; apex broadly recticular, the cells as broad as two ribs, quadrangular, then smaller cells, the micropyle with a circle of pyriform cells. Bluish green; diameter, $1 \mathrm{~mm}$.

Stage I.-Head rounded bilobed, held obliquely, pale brown. Body slender, rapidly vibrant looping, feet of joints 7 and 8 very short. Whitish translucent, green in the alimentary canal before eating, apparently from the green egg, which does not turn red. Tubercles moderate, black; shields concolorous, the elliptical leg plates of joints 9,10 , and 13 smoky.

Stage II.-Head elongate, the vertex full, oblique; gray whitish, shining, heavily black reticulate, forming a band on vertex of lobes from occiput to above clypeus; width, $0.6 \mathrm{~mm}$. Body slender, elongate, feet of joints 7 and 8 very short and not used; slaty gray, greenish diluted dorsally, brownish laterally; geminate dorsal, subdorsal, lateral and broad substigmatal gray lines, obscure. Cervical shield concolorous, leg shields olivaceous. Tubercles small, black, setæ moderate, black; joint 12 a little enlarged dorsally; thoracic feet pale.

Stage III.-Head round, full, clypeus depressed, blackish, dotted with white in six lines on vertex and a confused area over sides, a whitish gray bar each side of clypeus, clypeus gray with three erect black marks; width, $1 \mathrm{~mm}$. Body slender, anal feet long, divergent, those of joints 7 and 8 very short; joint 12 slightly humped dorsally. Blackish, diluted in sordid green on joints 5 to 7 ; wavy addorsal, straight subdorsal and lateral lines whitish; stigmatal and subventral lines similar, equally narrow. Feet pale, the abdominal ones gray 
without, the anal pair blackish like the body. Tubercles moderate, black; setre black, fine, rather long. The greenish, thickened part at joints 5-6 is held arched.

Stage IV.-Head bilobed, oblique, lobes full above clypeus, sutures depressed; black, dotted in white, leaving a bar on lobe above; width, $1.7 \mathrm{~mm}$. Body slender, tapering behind, joints 5 and 6 enlarged, an elevation on joint 5 posteriorly and a higher one on joint 12 , bearing the conical tubercle ii; feet of joints 7 and 8 not used, short. Black, green diluted on joints 5 and 6 . Dorsal, subdorsal, lateral stigmatal narrow wavy broken white lines; thoracic feet pale; tubercles small, with setæ black.

Stage V.-Head round, bilobed, erect, free, violaceous white, densely reticulate in black, clypeus streaked vertically, antennæ pink; width, $2.6 \mathrm{~mm}$. Body slender, looped up at joints $5-6$, tubercles ii on joint 12 forming a pair of cones; anal feet long, spreading; feet of joints 7 and 8 short and pale. Incisures of joints 4-5 and 5-6 conspicuously green, else bark gray; dorsal line geminate, waved, white; subdorsal narrow white, black edged above; lateral and stigmatal lines narrow, white, similar. Thoracic feet luteous, ringed in black; abdominal ones gray-lined with luteous plates except the anal pair. Tubercles white with black hair dots, $\mathrm{i}$ and ii of joint 5 conspicuous; a bright dilution on the side of joint 8 .

Stage VI.-Head round, prominent, higher and wider than joint 2, oblique, clypeal sutures depressed, reddish-brown bark color, freckled with little white spots which are aggregated in large groups leaving a line of the ground color from clypeus over tubercles i and ii; antennæ white, striped with pink without; labrum whitish with reddish marks; width, $3.7 \mathrm{~mm}$. Body rather slender, joint 5 enlarged dorsally and humped a little, joint 12 more sharply but less enlarged with high cones bearing setæ ii; feet of joints 7 and 8 shorter than the others but alike in color. Bark brown, tubercle ii of joint 5 white in a black spot, the cones ii of joint 12 dark red. Dorsal line white, geminate, waved, filled with white reticulations; subdorsal, lateral, substigmatal and subventral lines single, waved, dotted on a greenish ground, the greenish showing as a dilution about the hump on joint 5; a large misty white shade over joint 8; sides of joint 12 and all of 13 a little lightened. No shields; tubercles white marked; feet pale, the abdominal ones dull red within with white tubercles, the anal pair black lined; setæ fine, pale.

The larvæ fed on birch. They entered the ground to pupate.

\section{EPIZEUXIS ÆMULA Hüber.}

No specimens; one from Mr. Cockle's collection, August 2, 1902, is nearest this species, but differs in several characters. It is, however, in too poor condition to be made the type of a new name. 


\section{ZANCLOGNATHA OCHREIPENNIS Grote.}

No specimens; one in Mr. Cockle's collection.

BLEPTINA CARADRINALIS Guenée.

Fifty-six specimens, June 13, 16, 19, 20, 30, July 2, 4, August 5, 7. Eggs were obtained from captive females but the larvæ hibernated before reaching maturity. They fed on dead dry leaves.

Egg. - Conoidal with flattened base, perfectly smooth, scarcely even shagreened, shining pale yellow; diameter, $0.6 \mathrm{~mm}$.

Stage I.-Head rounded, bilobed, black, mouth brown, antennæ colorless; width, $0.25 \mathrm{~mm}$. Cervical shield bisected, with anal plate black. Feet of joints 7 and 8 short, the body normal, joint 12 a little enlarged. Colorless, translucent, tubercles large, black, angular; setæ with swollen tips, clear, the shaft subspinulose, dusky.

Stage II.-Head rounded, bilobed, whitish with a vertical blackish streak above the black ocelli; width, $0.4 \mathrm{~mm}$. Body short, robust, brown, shaded on the sides with vinous, incisures paler. Cervical shield blackish, broadly bisected; an obscure dark dorsal line; tubercles concolorous, setæ short, thick, capitate, the tips pale and contrasted.

Stage III.-Head sordid, dull, a black V-mark over clypeus and dash above eyes; width, $0.75 \mathrm{~mm}$. Body robust, flattened, joint 12 enlarged. Cervical shield quadrate, blackish with a central dilution. Body sordid smoky gray, marked by the white points of the capitate setæ; a darker dorsal line; sides irregularly diluted in pale in the incisures and folds. Hair dots black.

Stage IV.-Head as before; width, $1.1 \mathrm{~mm}$. Body the same, very dark, the dorsal line blackish. with oblique subdorsal bars from anterior addorsal to posterior lateral, indistinct. Setæ with white heads.

Stage V.-Head rounded, dull dark brown, a light band each side of clypeus; width, $1.8 \mathrm{~mm}$. Body robust, flattened, blackish brown, thickly dotted with lighter, darker laterally. A pale stigmatal line of the color of the dots, broken, diffuse, obscure. Setæ short, thick, swollen capitate, pale, contrasted on the dark ground; iv at the center of the spiracle, $v$ and vi nearly in line on the subventral fold.

The last stage, apparently, remains to be described.

PALTHIS ANGULALIS Hübner.

Two specimens, June 10, 15. An egg was obtained from one of the captured specimens, but the larva which hatched from it was accidentally lost.

Egg.--Rounded hemispherical, translucent whitish; about 40 low ribs not sharper than the hollows, covered by an uniform hexagonal 
reticulation of slightly raised lines, one junction at the summit of a rib, the next in the base of a hollow. Apex confusedly reticulate. Some irregular red spottings; diameter, $0.8 \mathrm{~mm}$.

Stage I.-Head rounded, bilobed, brown-black on vertex, pale below, shining. Body moderate, joint 12 a little eniarged, feet normal, equal; translucent brown, the small tubercles and shields blackish brown, including the cervical shield, leg plates, and anal plate. Setæ moderate, pointed, dark; thoracic feet black.

\section{HYPENA HUMULI Harris.}

Sixteen specimens, May 30, 31, June 2, 11 (bred), 12 (bred), 13, August 3, Sandon (G. C. Robbins) and one from Mr. Cockle's collection. Eggs were obtained and the larvæ fed on nettle.

Egg.-Flattened like one-third of a sphere, the base rounded, very flattened ellipsoidal; about 32 ribs, sharp, linear, high, fluted-waved, diminishing toward the micropyle which is marked by a cluster of elliptical cells; cross-striæ distinct but scarcely raised, arcuated downward in the deep grooves, forming rectangular cells about twice as wide as high. Color whitish, translucent, beaded by the ribs which look wide under a low power; later with irregular brown specks; diameter, $0.5 \mathrm{~mm}$; height, $0.3 \mathrm{~mm}$.

Stage I.-Head large, rounded, bilobed, colorless, eye black, mouth brown; body slender, submoniliform, semilooping, feet on joints 9 , 10 and 13. Colorless, transparent, unmarked, tubercles invisible, setæ pale.

Stage II.-Head high, narrowed to mouth, bilobed, free, transparent colorless, black spots on the tubercles, eye black, mouth brown. Body slender, semilooping, no feet on joint 7; transparent, food green, shields concolorous; tubercles small, black.

Stage III. - Head pale whitish with black tubercles; width $0.6 \mathrm{~mm}$. No feet on joint 7, the anal pair extended backward. Body transparent green, tubercles black, a distinct white subdorsal line.

Stage IV.-Head green with black tubercles; width, $1.3 \mathrm{~mm}$. Body slender, elongate, no feet on joint 7 , those of joint 8 small; transparent green with distinct white subdorsal stripe; tubercles moderate; concolorous, with black hair dots; setæ black, stiff.

Stage V.-Head green with many grayish black flecks over vertex; width, $1.9 \mathrm{~mm}$. Body semilooping, no feet on joint 7, those of 8 to 10 equal. Dorsum olivaceous green, subventer and venter clearer green; dorsal vessel dark, whitish edged; subdorsal line bright white, narrow. Tubercles pale, sordid, hair dots black. Hair rather long, dark; feet all green; spiracles black ringed.

Apparently finished in five stages, though it seems possible that stage iv was missed. 
HYPENA CALIFORNICA Behr.

Three specimens, June 1, 3, 10, and one from Mr. Cockle's collection, October 20, 1902.

\section{Family NYCTEOLID A.}

NYCTEOLA REVAYANA Scopoli.

Four specimens of this cosmopolitan species, August 3, 4, 7, 16. The larvæ were common on the balsam poplar, webbing up the young leaves in their well-known, characteristic manner.

\section{Family PERICOPIDA. \\ GNOPHÆLA LATIPENNIS Boisduval.}

One specimen, August 7, of the form found in Washington and the mountains of California with the yellow markings reduced.

\section{Family NOTODONTIDA. \\ MELALOPHA APICALIS Walker.}

No specimens; one in Mr. Cockle's collection.

MELALOPHA BRUCEI Hy. Edwards.

No specimens; Mr. Cockle has taken it.

HYPERÆSCHRA PACIFICA Behr.

No specimens; one in Mr. Cockle's collection. This form differs rather distinctly from the Atlantic region stragula Grote in the gray patch over cell and the straighter subterminal line.

\section{ODONTOSIA ELEGANS Strecker.}

No specimens; Mr. Cockle has taken it. I have described the larva on aspen from Coloradan specimens. ${ }^{a}$

\section{NOTODONTA SIMPLARIA Graef.}

No specimens; a single large female in Mr. Cockle's collection seems referable to this species.

\section{PHEOSIA DIMIDIATA Herrich-Schaeffer.}

One specimen, August 11. The moth was rare and the larvæ were not seen. The form agrees with Californian specimens and is not like the Pacific coast form portlandia $\mathrm{Hy}$. Edwards. 
NADATA GIBBOSA Smith and Abbot.

One specimen, June 2. The form is normal, like specimens from the Atlantic coast, not like the peculiar red or pale yellow forms that occur in certain places. The yellow marking in the cell of fore wing is well contrasted.

SCHIZURA IPOMCE $Æ$ Doubleday.

One specimen, July 4. Of the normal form without any black shadings. The species occurs throughout North America, except possibly in the Southwest. The well-known larva was not seen at Kaslo.

SCHIZURA CONCINNA Smith and Abbot.

No specimens; Mr. Cockle has taken it.

SCHETJRA UNICORNIS Smith and Abbot.

No specimens; Mr. Cockle has taken it.

SCHIZURA PERANGULATA Hy. Edwards.

No specimens; one in Mr. Cockle's collection, without date. Without a series I can not say positively that this is a local race, but such is probably the case. The specimen is nearest to one which I have from Ogden, Utah, as distinguished from others from Colorado. It has the fore wings a bright, nearly uniform gray, all the markings obliterate, except a heavy black shade at base and along basal twothirds of inner margin. The basal dash is present and the reddish shade on inner margin faintly so. Hind wings pure white, scarcely soiled at anal angle.

\section{HARPYIA SCOLOPENDRINA Boisduval.}

No specimen; Mr. Cockle has some referable to a form of this species.

\section{GLUPHISIA SEPTENTRIONALIS Walker.}

One specimen, July 25, and one from Mr. Cockle's collection, July 2, 1901. Mr. Cockle has taken others. They are of the form quinquelinea Dyar, which was described from Portland, Oregon. The larva was not seen; it feeds on aspen and cottonwood. These trees occur everywhere from the cold woods of Maine to the sun-baked arroyos of Arizona, and Gluphisia accompanies them. Naturally the adult varies much in appearance from the dark forms of the northern woods to the pale, almost white ones of the southern deserts. The North American forms have been variously called septentrionalis, clandestina, trilineata, ridenda, quinquelinea, wrightii, albofascia, rupta, and formosa, all described as good species. They have been gradually 
united, till but two so-called species are now listed. I think there is really but one, with a series of local races, each adapted to its special locality. I would therefore unite all the names under septentrionalis Walker.

GLUPHISIA LINTNERI Grote, var. SEVERA Hy. Edwards.

Two specimens, May (Mr. Cockle), May 30. The larvæ were later beaten from balsam poplar by Mr. Currie. A description has been published. ${ }^{a}$ This form has gone under the specific name severa $\mathrm{Hy}$. Edwards, but I am convinced, after seeing a small series, including several from Rossland, that the form varies enough to cover all the descriptions-lintneri, severa, danbyi, avimacula, and slossonii-and that we have but one species, not two. The western race (severa) is larger, broader winged and more shaggy looking, as well as generally darker in color. I would arrange the forms thus:

Smaller, narrower winged, lighter gray lintneri Grote.

Median space not darker than the rest of wing.

Yellow discal mark absent var. lintneri Grote.

Yellow discal mark present ... . . . . . . . . . . . . . . . var. avimacula Hudson.

Median space largely black ...................... . var. slossonii Packard.

Larger, broader winged, darker gray ................ . race severa $\mathrm{Hy}$. Edwards.

Median space not darker than the rest of wing.

Yellow discal mark absent ..................... var. danbyi Neumogen.

Yellow discal mark present var. normalis Dyar.

Median space largely black shaded var. severa Hy. Edwards.

The name normalis above is new. This is the usual form in the West, but no one has happened to name it.

Type.-Cat. No. 6990, U. S. National Museum.

\section{Family THYATIRID A.}

\section{HABROSYNE SCRIPTA Gosse.}

Fifteen specimens; July 14, 15, 19, 24, 25, 27, 30, August 2, 5, 6, 7 . These specimens agree exactly in markings with eastern scripta, but the general color is in all a little darker, more grayish, less yellowish. There is not enough difference for a varietal name, I think, though the character is constant. Grote named the Pacific Coast form chatfeldii, but I have a specimen from Vancouver Island from Mr. Taylor and it agrees exactly with scripta from New York, not differing even in the tint, as the Kaslo specimens do. Therefore I would make chatfeldii Grote a synonym of scripta Gosse. Larvæ were obtained from eggs laid by a captive female. They fed on thimbleberry.

Egg.-Elliptical, rounded, one diameter less; about 16 narrow raised ribs, confused at the ends, joined by neat cross striæ, forming cells over twice as wide as long; micropyler end larger and somewhat 
flattened. Pale yellow, turning red; size, 0.9 by 0.6 by $0.5 \mathrm{~mm}$. Laid singly on the flat side on the surface of the leaf.

Stage I.-Head rounded, bilobed, black. Body moderate, feet equal, joint 12 slightly enlarged, segments annulate. Colorless, the shields concolorous; tubercles small, brown, $\mathrm{v}$ higher than iv, no subprimaries; on joints 11 and 12 tubercle ii is dorsad to i, though not so on joints 5 to 10 ; setæ pointed, pale.

Stage II.-Head bilobed, white, with rows of gray spots radiating from the clypeus and in blotches on the sides; width, $0.7 \mathrm{~mm}$. Body with joints 3 and 4 slightly squarely enlarged, anal feet elevated, joint 12 enlarged. Whitish over joints 3 and 4 , dorsum and sides infiltrated with luteous gray; subdorsal region, dorsum of joints 2, 3, and 12 and subventral region darker gray. Feet pale, the anal pair dark. Tubercles small, dark; setæ moderate.

Stage III.-Head-bilobed, full, flat before, clypeus small; whitish, thickly dotted with black except streaks on faces of lobes and ocelli; width, $1.2 \mathrm{~mm}$. Joint 3 posteriorly enlarged, also joint 12 dorsally; anal feet elevated. Gray-black, washed with white dorsally on joints 3 and 4 , from there along the sides and in oblique streaks to a geminate white dorsal line. Tubercles small, dark, their bases a little elevated. Setæ pale, small; feet pale, the anal pair dark.

Stage IV. - As before, the dots on the head brown; width, $2.2 \mathrm{~mm}$. Body brown, velvety, washed with white as before, a series of white spots subventrally. Feet very pale, white except the anal pair. During the stage the colors became well contrasted and pretty, velvety brown and yellowish-white.

Stage V.-The colors change entirely to brown like Pseudothyatira. Head large, bilobed, squarish, clypeus small; white, thickly dotted with brown except in pale streaks in front of lobes, paraclypeus smoky brown, clypeus dull olivaceous; width, $3 \mathrm{~mm}$. Body moderate, joints 3 and 4 a little enlarged dorsally, joint 12 enlarged; dark brown, blackish shaded, reticulate; dorsal line narrow, black with dark oblique shades over two segments to the spiracles, a lighter area along the stigmata, illy defined but conspicuous; feet pale.

\section{PSEUDOTHYATIRA CYMATOPHOROIDES Guenée.}

Twenty-five specimens; June 13, 18, 19, 25, 27, 30, July 2, 15, 17, 21, 25, August 1, 6. They agree with specimens from the Atlantic coast and Pacific region. The larvæ were bred on thimbleberry from eggs laid in long strings on the tips of the leaves. The life history has been previously described by me. ${ }^{a}$

a Proc. Boston Soc. Nat. Hist., XXVI, 1895, p. 400; in error as Habrosyne scripta. 


\section{PSEUDOTHYATIRA EXPULTRIX Grote.}

Six specimens; June 16, July 2, 14, 19, 25. They agree with specimens from the Atlantic States and Pacific coast. Eggs were obtained from a captive female, laid in long strings on the tips of the leaves. I provisionally regard this form as a distinct species from cymatophoroides Guenée. There are no intergrades in the moths. The larvæ of expultrix showed no white lateral spots, while those of cymatophoroides did in most cases. In a group where the larvæ are so much alike as they are here, this difference may be of some value. Some differences were observed between the eggs, but they may be of an individual character rather than specific. Both sets of larvæ had five stages and were indistinguishable except as noted above. I need not, therefore, transcribe my notes.

\section{EUTHYATIRA PUDENS Guenée.}

No specimens; Mr. Cockle has one so named. The food plant, Cornus, occurs at Kaslo, but none of the characteristic larvæ were seen on it.

\section{Family LIPARID A.}

\section{NOTOLOPHUS ANTIQUA Linnæus.}

No specimens; Mr. Cockle has the species, but whether of the coast form badia Hy. Edwards or not, I can not say, not having seen the larva.

OLENE PLAGIATA Walker.

No specimens; one from Mr. Cockle's collection, July 18, 1902.

$$
\text { Family LASIOCAMPID A. }
$$

\section{MALACOSOMA PLUVIALIS Dyar.}

Fifty-eight specimens, July 13, 14, 15, 16, 17, 18, 25, 30, August 3 (Sandon, Mr. Currie). The moths and larvæ agree with specimens from the Pacific coast. The larvæ are a little less orange colored, some specimens having the orange marks considerably reduced, the blue marks distinct, suggesting fragitis Stretch of Colorado, but they do not diverge sufficiently from pluvialis for even racial distinction. The species has recently been called synonymous with californica Packard; but there is, of course, no warrant for that. Californica is a very near relative of pluvialis and single specimens of the adult are not distinguishable, but the larva differs in the great reduction of all its markings, both blue and orange, so that it looks black. Furthermore it is an oak feeder, while pluvialis is addicted to other plants. This precludes considering the forms otherwise than as distinct species. 
A number of nests of the larvæ were found at different times eariy in spring on several deciduous trees. A fresh egg mass was noted on a birch twig in August.

EPICNAPTERA AMERICANA Harris.

One example, June 2, almost typical americana like Atlantic coast specimens. There is a little obsolescence of the white markings, indicating the first step toward the variety fermginea Packard. The larvæ were beaten from Ceanothus and were of the normal appearance.

\section{Family PLATYPTERYGID A.}

DREPANA ARCUATA Walker, var. SICULIFER Packard.

No specimens; Mr. Cockle has a few in his collection. As I recollect, they are similar to those occurring on the coast which I have from Seattle, Washington (Kincaid), Wellington (Taylor), and Portland, Oregon (Dyar). In Bulletin No. 52 of the U. S. National Museum, I listed siculifer as a distinct species, but I would no longer maintain that. The race is larger only. Both spring and summer forms occur, differing as do the eastern forms arcuata Walker and genicula Grote. A few larvæ occurred on alder with the appearance and habits of the eastern race.

\section{FALCARIA BILINEATA Packard.}

No specimens; but Mr. Cockle has six in his collection. They probably do not differ from a specimen that I have from Wellington (Taylor). It is the same as the Atlantic coast form, being scarcely larger even. Mr. Cockle has both the forms bilineata Packard and levis Hudson. His dates are: Spring form bilineata, June 17, July 7; summer form levis, July 31.

A few larvæ occurred on birch with the appearance and habits of the Atlantic coast form.

\section{Family GEOMETRID A.}

NYCTOBIA NIGROANGULATA Strecker.

One specimen, June 2, in bad conditıon, and one from Mr. Cockle's collection, April 3. I have the species also from Seattle, Washington (T. Kincaid), Wellington (T. Bryant) and Rossland (W. R. Johnson). The Rossland specimen was seriously misidentified for me by the late Doctor Hulst, who called it Hydriomene californiata Packard var., so that I lost sight of the form for several years. It is, I think, only a western race of limitata Walker or furcifascia Walker, being larger and darker; but I do not wish to enter into the question of the specific distinctness of these eastern species with my present material and without knowing any larvæ. Therefore I provisionally let nigroangulata stand. 
TAlledega MONTANATA Packard, var. MAgnoliatoidata, new variety.

Nine specimens, May 31, June 8 (Ainsworth), 10, July 21 (Bear Lake, Mr. Cockle), and one from Mr. Cockle's collection, June 9, labeled Enchoria osculata Hulst, but erroneously. It differs from the eastern montanata in the much darker colors, the pale lines more contrasted, the pinkish tint of the hind wings and the evident submarginal line. A specimen of this form is mentioned by Doctor Packard as from Colorado $^{a}$ and said to differ from eastern specimens. It is, I think, a good geographical race.

Type.-Cat. No. 7103, U. S. National Museum.

TEPHROCLYSTIS RAVOCOSTALIATA Packard.

Two specimens, June 1, and one in Mr. Cockle's collection, May 4, 1901.

TEPHROCLYSTIS LAQUÆARIA Herrich-Schaeffer.

No specimens; one in Mr. Cockle's collection, June 1, 1902, resembles rather nearly the European laquxaria. The transverse-anterior shade is more blackish than brown and the costal shading just before the discal dot is blackish and pronounced, while the pale band beyond the dotted-cuneiform transverse-posterior line forms a rather distinct white blotch on the costa not noticeable in the European form.

TEPHROCLYSTIS ABSINTHIATA Clerck.

No specimens; one in Mr. Cockle's collection, May 27, 1902, resembles the European absinthiata, but the basal two-thirds of the wing is paler than the terminal portion, not unicolorously brownish as in the European species. The costal black dashes are well marked and one of them is bent, joining the discal spot. The form stands midway between absinthiata Clerck and expallidata Guenée. The latter has the ground color entirely pale.

\section{TEPHROCLYSTIS SATYRATA Hübner.}

Sixteen specimens, May 30, 31, June 3, 7, 11, 13, 20, 22, 25, July 4, 27, June 25, 1901 (Golden, Colorado), and six from Mr. Cockle's collection, May 13, 27, 1902, June 11 and July 7, 1901. The specimens

a Mon. Geom., 1876, p. 182.

$b$ The following determinations in Tephroclystis are made at a disadvantage. The National Museum collection is unequally poor in this genus, and there exists no table for the determination of the species. Hulst's descriptions are made without any comparisons or statement of salient characters and are nearly worthless in the case of these closely allied and difficult forms. Under these circumstances it became necessary to examine the Hulst collection, now in the charge of Dr. John B. Smith at New Brunswick, New Jersey. I made repeated applications to him, but he failed to make the collection accessible to me.

Proc. N. M. vol. xxvii-03-61 
are a little larger than the European form and without any brown tint. Some of my specimens from Norway are of exactly the same color. This may be $T$. perfusca Hulst. It is obviously the same as the Alaskan specimens named perfusca for me by Doctor Hulst, but Hulst's type from Utah before me is so poor that I can not tell what it is like. Eggs obtained from a captive female proved sterile.

Egg.-Elliptical, well flattened, rounded, truncation and depression distinct, all rounded; uniformly reticulate with waved reticulations, broad, rounded, forming cells with five lobes but not neatly, not very distinctly, and tending to run in the long diameter. Yellowish white, shining; size, 0.6 by 0.5 by $0.4 \mathrm{~mm}$.

\section{TEPHROCLYSTIS LARICATA Freyer.}

No specimens; one in Mr. Cockle's collection comes near the European laricata. The markings are more pronounced and contrasted, the outer pale band being broader and less obscured by its centering line. The discal dots on both wings are well marked.

TEPHROCLYSTIS MULTISTRIGATA Hulst.

One specimen, April 22 (Mr. Cockle), and one in Mr. Cockle's collection, May 7, agree in general with a specimen from Calgary, Alberta, communicated to me by Mr. George W. Taylor. The agreement is not absolute, but I will not venture to separate them on the present slender material.

TEPHROCLYSTIS NIPHADOPHILATA, new species.

Twenty specimens, June 7, August 10 (Kokanee Mountain, on snow), September 8 (Glacier), 9 (Field), and two from Mr. Cockle's collection, August 22, 1901. Dark gray, the wings rather pointed; a light band followed by black on basal segments of abdomen. Lines not contrasted, both well angled subcostally, the veins marked with black dashes, especially the median vein and those before the transverse posterior band. Subterminal line faint, pale, not forming a dot above tornus. Discal spot black. Hind wings gray, subpellucid, with gray lines on the inner margin and two faint outer pale lines across the wing. Expanse, $24 \mathrm{~mm}$.

Type.-Cat. No. 7823, U. S. National Museum.

TEPHROCLYSTIS COOTENAIATA, new species.

One specimen, June 16, and one in Mr. Cockle's collection, July 17, 1901. Gray, the dark band on second segment of abdomen not contrasted. Wings nearly uniform gray, the lines nearly obsolete, pale; discal spots large, black. Hind wing indistinctly lined, with small, faint, discal dot. Expanse, $26 \mathrm{~mm}$.

Type.-Cat. No. 7825, U. S. National Museum. 
TEPHROCLYSTIS CASLOATA, new species.

One specimen, July 15, and one in Mr. Cockle's collection, July 28, 1901. Light gray, the dark band on second segment of abdomen distinct, not deep black. Lines moderately distinct, blackish on a gray ground, crenulate on the veins, emphasized on costa. Discal spot black. Subterminal line white, crenulate, forming a spot above tornus. Hind wing rather distinctly lined, the dark submaculate mesial line following a smoky black discal spot. Expanse, $23 \mathrm{~mm}$.

Type.-Cat. No. 7824, U. S. National Museum.

Eggs were obtained from my specimen and hatched, but the food plant was not discovered.

Egg.-Elliptical, narrowed toward the antemicropylar end, ends rounded, one diameter less, no flat areas. Reticulations rounded, low raised from a smooth surface, neat, rather narrow, hexagonally reticulate, waved, not strongly stellate. Shining yellowish white. Size, 0.6 by 0.5 by $0.4 \mathrm{~mm}$.

Stage I.-Head slightly bilobed, pale luteous, eye black. Body moderate, not elongate, segments about 6 annulate. White, immaculate, shields and feet a shade darker. Tubercles moderate, blackish, hair dots elevated; setæ rather long, with enlarged tips.

TEPHROCLYSTIS COLUMBIATA, new species.

One specimen, May 31, and one in Mr. Cockle's collection, May 4, 1902. Wings pointed; band on abdomen black, distinct, following a whitish space. Wings gray, tinged with russet outwardly mesially; lines black, the transverse-posterior finely crenulated, the points within, scarcely excurved over cell; discal spot narrow, black. Subterminal line white, crenulated, black edged within, forming a spot above tornus; marginal black line forming cuneiform spots between the veins. Hind wings whitish, with four dark gray lines nearly erossing the wing, the first and third not distinct. Expanse, $19 \mathrm{~mm}$.

Type.-Cat. No. 7821, U. S. National Museum.

TEPHROCYSTIS BIFASCIATA, new species.

One specimen, June 25, and one from Mr. Cockle's collection, June 13. Gray; abdominal band obsolete. Fore wing with narrow scales, gray, indefinitely marked; a broad, nearly white band at outer third just beyond the large, black discal spot; transverse posterior line whitish, geminate, both strongly angled subcostally, contrasted with the pale-gray ground color which is without distinct black lines. Slight black dashes subapically before and following the transverse posterior line. Subterminal line pale, linear, subobsolete. Hind wing pale, the outer two of the dark lines nearly crossing wing, the basal two abbreviated at the margin; discal dot faint. Expanse, $20 \mathrm{~mm}$.

Type.-Cat. No. 7820, U. S. National Museum. 
TEPHROCLYSTIS SUBFOVEATA, new species.

Three specimens, June 1,5. Wings elongate, rounded. Hind wing of male with a large area on upper side over cell clothed with smooth appressed scales, which in certain lights are shining silky while the rest of the wing is dull. Obscure gray; costal edge dotted in black. Lines obsolete, the transverse-posterior faintly paler gray; terminal area darker; discal spot black. Hind wing with the lines blackish, dotted, those below the cell crossing the wing. Terminal black dashes on both wings. Abdominal blackish line present, following a basal light ashen space. Expanse, $18 \mathrm{~mm}$.

Type.-Cat. No. 7822, U. S. National Museum.

Egg.-Elliptical, the depressed end broadened, narrowing to the truncate end; flattenings rounded. Smooth, except for slight reticulations composed of rather broad, slightly raised lines with parallel edges, irregularly hexagonal, a little elongate in the long diameter, and gently waved. Pale yellow, irridescent under 85 diameters. Size 0.6 by 0.5 by $0.4 \mathrm{~mm}$.

Stage I.-Head squarish bilobed, pale testaceous, smoky shaded, eye black, mouth brown. Body moderate, flattened, translucent testaceus, faintly smoky shaded. Tubercles concolorous, obscure; feet and setæ pale, normal.

Stage III.-Head bilobed, whitish; eye black; width $0.6 \mathrm{~mm}$. Body slender, waxy whitish, with narrow smoky black dorsal line. Segments finely annulate; setæ short, capitate, alternately forward and backward. Feet all brownish tipped; no marks.

Stage IV.-Head bilobed, whitish, the lobes thickly brown dotted, arranged obscurely in two vertical bands; width $1 \mathrm{~mm}$. Body rather slender, not much elongate, whitish or pale green, not shining, granular shagreened. A broad dorsal smoky brown band widened between tubercles i and ii; a subdorsal series of cuneiform brown marks. Tubercles concolorous, setæ short, dark, alternately directed forward and backward. Thoracic feet brownish ringed.

The larvæ fed on flowers of Ceanothus. I missed the second stage.

\section{EUCYMATOGE GRANDIS Hulst.}

Three specimens, July 25, August 4, and three from Mr. Cockle's collection, July 21 (Bear Lake), October 16, 1902. Most of the specimens have the discal spot strongly tinged with bright brown and are thereby readily recognizable. One of Mr. Cockle's specimens (October 16) has a brown shade running outward from the spot nearly to the margin, resembling a very distinct form from Vancouver Island, of which I have a specimen from Mr. George W. Taylor 
EUCYMATOGE LINARIATA Fabricius.

No specimens; one from Mr. Cockle's collection closely resembles the European linariata. The mesial dark band is more excurved over the cell and the outer mesial pale band of hind wings is likewise more bent. The specimen is a true Eucymatoge, having two accessory cells on the fore wings; vein 12 separate from vein 11, and two pairs of spurs on the hind tibiæ.

\section{EUCYMATOGE INTESTINATA Guenée.}

No specimens; one from Mr. Cockle's collection taken June 1.

\section{VENUSIA CAMBRICA Curtis.}

Two specimens, July 21 (Bear Lake Mountain), 25, and one from Mr. Cockle's collection July 1.

\section{VENUSIA DUODECEMLINEATA Packard.}

One specimen, June 11 (Mr. Currie), and one from Mr. Cockle's collection April 28, 1901.

\section{EUCHCEA ALBOVITTATA Guenée.}

Six specimens, August 9 (South Fork Creek), 11 (South Fork Creek); all taken from horseback, on the trail to Kokanee Mountain, at altitudes higher than Kaslo.

EUCHECA CRETACEATA Packard.

Fourteen specimens, July 22, 29 (Bear Lake Mountain), 31, August 5, 9 (South Fork Creek), 10 (Kokanee Mountain), 13 (Sandon, Mr. Currie), Sandon (G. C. Robbins). A high-altitude species, occurring also at Kaslo, but less commonly.

\section{EUCHCCA ALBIFERA Walker.}

Seven specimens, June 11 (Fletcher's Ranch), and one from Mr. Cockle's collection June 11, taken at the same place. This seems to be the eastern albifera, as it lacks the blackish tip to the fore wing which Vancouver Island specimens have (var. bmenneifasciata Packard). Still, the lines are pale brown rather than ocherous, as Doctor Packard describes the eastern form. It is therefore probable that we have here a local race which could be distinguished by name, but as I have no eastern specimens before me, I can not judge of the actual amount of difference.

\section{EPIRRITA DILUTATA Schiffermüller.}

One specimen, September 8 (Glacier). 
CORYPHISTA MEADII Packard, vąr. BADIARIA Henry Edwards.

Five specimens, June 13, July 21, 25, 31, August 1. Both forms occurred, meadii being the usual one. The true badiaria looks very distinct, and Mr. G. W. Taylor has pointed out to me that there are no intergrades, yet I think it is only a varietal form. A typical badiaria was bred from a larva on barberry. My description of the larva of badiaria ${ }^{a}$ should be applied to meadii, as we took no true badiaria in Colorado, though one specimen is very near it. The two larvæ are, however, indistinguishable. I observed all the stages in the Kaslo specimens.

HYDRIA UNDULATA Linnæus.

One specimen, July 21 (Bear Lake Mountain, Currie and Caudell). Observations on this larva should be made. I have described the eastern form, ${ }^{b}$ but in the West Prunus serotina, the food plant, does not occur, nor have the peculiar nests of the larvæ ever been noted, so far as I can discover.

\section{EUSTROMA DESTINATA Moeschler.}

Sixteen specimens, August 11 (South Fork Creek, Mr. Cockle), 20 (West Robson), September 7 (Glacier), 8 (Glacier), 9 (Field). None taken at Kaslo, though Mr. Cockle has some in his collection.

\section{EUSTROMA POPULATA Linnæus.}

Two specimens, July 21 (Bear Lake Mountain), Sandon (G. C. Robbins). They are of the variety packardata Lintner, agreeing exactly with a specimen from Yosemite, California (J. B. Lembert), and less closely, but still very nearly, with Lintner's type before me. There are a number of differences between this form and the European populata, and I suspect that packardata will be found to be a distinct species. I have specimens of the true populata from Clatsop County, Oregon (H. Ahlers), and Wellington (T. Bryant). Mr. Cockle has latterly sent me a true populata from his collection, taken August 10 (South Fork Creek).

\section{EUSTROMA CERVINIFASCIA Walker.}

One specimen, August 13 (Sandon, Mr. Currie) and two from Mr. Cockle's collection August 10 (South Fork Creek) and August 13, 1902, all three females. The specimens are alike and agree well with the original colored figure of Walker's type which Doctor Packard used for the figure in his monograph. They differ markedly from populata and 
packardata in the ground color being gray with the broad median area bright chestnut brown. I feel sure the species is a perfectly distinct one and not a variety of populata. ${ }^{a}$

\section{EUSTROMA NUBILATA Packard.}

Sixty-five specimens, May 31, June 1, 4, 10, 11, 15, 20, 23, 24, 30 , July 15, 18, 21 (Bear Lake Mountain), 23, 29 (Bear Lake Mountain), 29, 30, August 1, 4, 5, 6, 7, 9 (South Fork Creek), 10 (Kokanee Mountain), 11 (South Fork Creek), 15, 21 (Revelstoke), 22 (Revelstoke), Sandon (G. C. Robbins). Probably double brooded, the broods overlapping. The moths are rather variable, especially in the width of the pale transverse-anterior band of the forewings. One specimen is distinctly aberrant, the band being wideand pale, while the outward projection of the dark median space is represented only by two short teeth and there is a pale shade about the discal dot. The larvæ were obtained from eggs laid by a captive female and bred on Epilobium. The description will appear in my Life Histories of North American Geometridæ, LIII, in Psyche.

\section{NEOLEXIA XYLINA Hulst.}

Twenty-three specimens, July 27, 29, 31, August 3, 4, 5, 6, 13, 15, 18, September 8 (Glacier), 9 (Field). A constant and characteristic species. The larva was not found.

RHEUMAPTERA HASTATA Linnæus.

Twenty-seven specimens; May 29, June 2, 8 (Ainsworth), 18 (Kaslo Creek, Mr. Caudell), July 21 (Bear Lake Mountain), July (near MeGuigan), 29 (Bear Lake Mountain), August 9 (South Fork Creek), 11 (South Fork Creek). Many more could have been taken, as the species was very common at high altitudes.

\section{RHEUMAPTERA SOCIATA Borkhausen.}

Seven specimens; June 18 (Kaslo Creek, Mr. Caudell), 22, 23; July 21 (Bear Lake, Mr. Cockle), 25, August 1 (South Fork Creek) and one from Mr. Cockle's collection, June 11. Agrees well with European specimens. I have the species also from Oregon (Koebele), Seattle, Washington (T. Kincaid), Vancouver (R. V. Harvey) and Wellington (T. Bryant).

\section{RHEUMAPTERA LUCTUATA Schiffermüller.}

Three specimens, August 7, 9 (South Fork Creek), 11 (South Fork Creek, Mr. Cockle), all with black hind wings (var. obductata Möschler). I am clearly of the opinion that there are too many varietal names recognized of this species. Hulst gives kodiakata, obductata, and con- 
cordata. I would make concordata synonymous with obductata and kodiakata with luctuata. In Staudinger and Rebel's catalogue the species is called lugubrata Staudinger, the name luctuata being used for a different form (hastulata Hübner). This depends upon the interpretation of Denis and Schiffermüller's work, Staudinger and Rebel regarding the name lugubrata of Schiffermüller as a nomen nudum and recognizing the next use of it by Hübner (1786), which was in a different sense. Hulst, in Bulletin No. 52 of the U. S. National Museum, regarded Schiffermüller's name as valid. Which is correct I am not prepared to say, as I have not Schiffermüller's work before me; but in any case lugubrata can not stand, as Möschler's name obductata has ten years priority.

\section{RHEUMAPTERA GEORGII Hulst.}

No specimens; one from Mr. Cockle's collection without date. The species flies in August and September and probably had not begun to appear at the time I left Kaslo. I took it in September at Victoria.

\section{MESOLEUCA RUFICILIATA Guenée.}

Ten specimens, May 31, June 4, 7, 8 (Ainsworth), 19, July 15, August 9 (South Fork Creek). The dates indicate two broods. Eggs were obtained from a captive female but proved infertile.

Egg.-Elliptical, rather thick, flattened above and below in a small area, depression distinct, truncation distinct but rounded. Very finely pitted shagreened, the cell areas showing by slightly raised broad, indistinct reticulations, evenly pitted all over, one cell area containing about 12 pits. Pale green; size, 0.8 by 0.6 by $0.5 \mathrm{~mm}$.

\section{MESOLEUCA GRATULATA Walker.}

Three specimens, May 29, and one from Mr. Cockle's collection, April 15, 1901. I have described the larva in Life Histories of North American Geometridæ, XLIV. ${ }^{a}$

\section{MESOLEUCA C ÆSIATA Schiffermüller.}

Twenty-eight specimens, June 13, August 6, 21 (Revelstoke), September 8 (Glacier), 9 (Field), 10 (Banff, Alberta). The dates indicate two broods. This is a high altitude species, only three specimens being taken at Kaslo.

\section{MESOLEUCA LACUSTRATA Guenée.}

Two specimens, June 10 (Mr. Cockle), 11 (Fletcher's ranch). Eggs were obtained from a captive female and hatched, but no suitable food plant could be found, the larvæ refusing everything offered them. 
Egg.-Elliptical, flattened, depression and truncation well marked, rounded, normal; reticulations stellate-waved, irregular, of various sizes, moderately raised, distinct, but the cell areas very shallow. Surface finely punctate shagreened all over. Pale yellow, turning reddish; size, 0.8 by 0.6 by $0.4 \mathrm{~mm}$.

Stage I.-Head rounded, bilobed, pale brown, shining, with two rows of purplish spots on each lobe, setæ rather long. Body moderate, rather slowly looping, pale whitish with longitudinal brown bands about as wide as the spaces, dorsal, subdorsal and lateral approximate, subventral and ventral. Feet pale; tubercles small, brown; setæ short, dark, glandular tipped.

\section{MESOLEUCA TRUNCATA Hufnagel.}

Thirty-four specimens, June 14, 23, July 17, 29 (Bear Lake), August 6, 7, 9 (South Fork Creek), 18, 21 (Revelstoke), 22 (Revelstoke), 8 (Glacier), 9 (Field). Sandon(G. C. Robbins). The series shows the usual amount of variation, but none of the extreme forms are present. The species much resembles Mesoleuca hersiliata Guenée. One specimen was bred by Mr. Cockle, but I have not his notes on the larva.

\section{MESOLEUCA HERSILIATA Guenée.}

Fifteen specimens, mostly bred from larvæ on currant, June 16, 18, 21, 29, July 4, 14, 21 (Bear Lake), 29 (Bear Lake Mountain) and one from Mr. Cockle's collection. The variation is marked. Most of the specimens are dark, though a few are very light, as light as any that I have from Placer County, California (Koebele), Victoria (Hanham). I suspect that a light specimen of this formed Hulst's type of ethela and Mr. G. W. Taylor has recently sent me a specimen so marked. If so, that name may be used for the western race of hersiliata which certainly differs markedly in appearance from eastern specimens. The light red bands (which induced Walker's synonymic name flammifera) are never present, being replaced by rusty brown or cream color; the transverse anterior band is narrower, usually more dentate and directed obliquely outward from costa to inner margin instead of inward. All my British Columbian and nearly all the Californian specimens show these characters, but the Coloradan ones are intermediate, some showing the narrow oblique bands, others the erect broader ones, but they agree with the Pacific coast specimens in color.

Larva.-Head rounded, slightly bilobed, roughly shagreened, pale luteous green, the setæ small and white; width, $1.5 \mathrm{~mm}$. Body moderately slender, the skin densely clothed with minute secondary spines and roughened by the slightly elevated, small, white tubercles; green, the dorsal vessel darker, a distinct white subdorsal line from joint 2 to 13 and trace of a lateral one; a similar but broken medio- 
ventral line. Ventral tubercles white like the dorsal ones; setæ coarse, white, not long; all feet green, the abdominal ones normal on joints 10 and 13 .

Cocoon a net of yellowish silk among the leaves. Pupa green with a white dorsal stripe.

Food plant, currant (Ribes sanguineum).

\section{MESOLEUCA ALBOLINEATA Packard.}

Five specimens, June 3, 6, 11, July 21 (Bear Lake, Mr. Cockle), August 6, and one from Mr. Cockle's collection, July 18, 1902. Eggs from a captive female proved infertile.

Egg.-Elliptical, rounded, one diameter less, scarcely any depression, truncation rounded; densely finely reticulate, the reticulations elongate in the long diameter, hexagonal, normally alternating, rather low, broad, and rounded, the surface all over slightly shagreened. Pale yellow; size, 0.8 by 0.6 by $0.5 \mathrm{~mm}$.

\section{MESOLEUCA VASALIATA Guenée.}

Seven specimens, May 31, June 2, 5, 6, 7, 8. The larvæ were bred on thimbleberry. I will describe them in Life Histories of North American Geometridæ, LVIII.

MESOLEUCA SIMULATA Hübner, var. OTISI, new variety.

Eleven specimens, all females, September 8 (Glacier), 9 (Field). The specimens are stone gray throughout without any of the brown tint seen in examples from the Alps of Europe, but all the lines and markings are exactly alike. The species has not been hitherto recorded in America. The American form is named for my son, Otis P. Dyar, who assisted me in collecting the specimens. The form resembles Hydriomene contractata Packard, as Mr. G. W. Taylor pointed out to me, but it lacks the distinct thoracic tuft of that form and is without its warm brown tint.

Type-Cat. No. 7105, U. S. National Museum.

\section{HYDRIOMENE SORDIDATA Fabricius.}

Two hundred and fifty-nine specimens, July 15, 21, 24, 26, 27, 31, August 11 (South Fork Creek), 12, 13, 17, September 9 (Field), Sandon (G. C. Robbins). Very variable in the markings, but constant in color, all examples being shades of brown, greenish gray, and black, none of the light forms appearing. All the specimens are rather large. The larva was not obtained. Living females were repeatedly confined in jar's, but all refused to deposit eggs. 


\section{HYDRIOMENE AUTUMNALIS Stromeyer.}

One specimen, July 2 and one from Mr. Cockle's collection, July 10 (Ainsworth). The specimens are distinctly smaller than sordidata Fabricius.

\section{HYDRIOMENE T $Æ N I A T A$ Stephens.}

Five specimens, July 29 (Bear Lake), August 9 (South Fork (reek), 11 (South Fork Creek), much worn, but apparently agreeing with Walker's basaliata, which stands as a synonym of treniata in our list. I have one specimen of European treniata and I should hardly think it conspecific with my Kaslo specimens. Hence this synonymy appears doubtful to me, but I can make no positive statement with the present scanty material.

\section{HYDRIOMENE EXCURVATA Grote.}

Three hundred and fifteen specimens, June 26, July 2, 4, 11, 19, 24, 30, 31, August 3, 4, 5, 6, 11 (South Fork Creek), 12, 13, 15, 17. This was the commonest species of Geometridæ in Kaslo. It is the Ceratodaiia queneata of Packard's monograph. The larvæ hibernate at various stages and produce a single brood of moths. I have described them in Life Histories of North American Geometridæ, XLVII. ${ }^{a}$

\section{HYDRIOMENE MULTIFERATA Walker.}

Six specimens, May 31, June 4, 7, 8. The larva has been described by me in Life Histories of North American Geometridæ, XLVI. ${ }^{b}$

\section{HYDRIOMENE MAGNOLIATA Guenée.}

Thirty-five specimens, May 31, June 1, 3, 7, 10, 11, 16, 18 (Kaslo Creek, Mr. Caudell), 23, 25, July 13, 14, 15, 18, 29 (Bear Lake), 30, 31, August 1, 2, 4, 5, 6, 7, 11 (South Fork Creek). The dates indicate two broods. The larva has been described by me in Life Histories of North American Geometridx, XLV, ${ }^{c}$ where I show that the species is referable to Hydriomene instead of Conocalpe and that Hulst's pernotata is a synonym.

\section{TRIPHOSA PROGRESSATA Walker.}

No specimens; one in Mr. Cockle's collection, October 20. I should have probably taken the species myself if I had remained later in the season.

GYPSOCHROA DESIGNATA Hufnagel.

No specimens; one in Mr. Cockle's collection, June 4. 


\section{TRICHOCHLAMYS LACTEATA Packard.}

No specimens; one in Mr. Cockle's collection, August 8 (South Fork Creek), a little smaller and more shaded with brown than specimens from Wellington, Oregon, and California.

\section{PETROPHORA ABRASARIA Herrich-Schaeffer.}

Twenty-two specimens, June 23, 25, 26, 30, July 2, 10, 11 (Ainsworth), 18, 19, 21 (Bear Lake), 23, August 4, 9 (South Fork Creek), 11 (South Fork Creek), and one from Mr. Cockle's collection, July 10 (Ainsworth). Eggs were obtained from captive females, but the larvæ could not be carried beyond the second stage on account of their propensity to hibernate.

Egg.-Elliptical, compressed, one end very strongly depressed, wedge-shaped from side view, ends rounded, the large one scarcely flattened. Cell areas depressed, flat-bottomed, the reticulations low, raised, corrugated, or wrinkled transversely, pentagonal to hexagonal. Pale yellow; size, 0.8 by 0.6 by $0.5 \mathrm{~mm}$.

Stage I.-Head rounded, brown black, scarcely bilobed, darker on the sides; width, $0.3 \mathrm{~mm}$. Body short and stout, the segments wrinkly annulate, feet normal, moderate. Yellowish white, with lines of fine blackish dots along the sides, indefinite yet distinct subdorsal, lateral and subventral rows. Cervical shield, anal leg shields and thoracic feet smoky. Tubercles minute; setæ short, bladder-shaped; skin minutely granular, the dots of the illy-defined dark bands underlying the granules.

Stage II.-Head rounded, dark brown, darker on the sides; width, $0.55 \mathrm{~mm}$. Body moderate, somewhat flattened, dorsum pale brown, with dorsal and subdorsal darker lines. Sides dark brown; subventral region broadly pale, like the dorsum; venter also pale, with faint darker lines, subventral and medioventra $\quad$ Tubercles and setæobscure; no shields.

\section{PETROPHORA CONVALLARIA Guenée.}

Twenty specimens, June 8, 9, 16, 19, 22, July 4, 30, September 5 (Victoria), Sandon (G. C. Robbins). After carefully studying Guenée's description with Mr. G. W. Taylor, I am satisfied that we have correctly identified this species. Hulst's nemorella from Alaska is scarcely more than a color variety of this, and both will be found to unite with the European munitata Hübner. I shall describe the larva in Life Histories of North American Geometridæ, LXI.

\section{PETROPHORA DEFENSARIA Guenée.}

Four specimens, June 4, August 21 (Revelstoke), 25 (Victoria), 26 (Victoria), and one from Mr. Cockle's collection, August 14, 1901. This is very closely allied to munitata $(=$ convallaria $=$ nemorella $)$, but 
distinct, I think. The larva was not obtained. Mr. Taylor has pointed out to me, and the experience of other resident collectors in British Columbia corroborates him, that in 1902 and previously defensaria was the common species, while convallaria was rare, while in 1903 the conditions were reversed. This is in agreement with my captures and appears to me to further indicate the distinctness of the two species.

\section{PETROPHORA FERRUGATA Clerck.}

Two specimens, June 24 (Mr. Cockle), August 22 (Revelstoke), and two from Mr. Cockle's collection, July 31, 1901, August 23, 1902, the latter a female apparently agreeing with Hulst's borealis.

\section{COSYMBIA LUMENARIA Hübner.}

Seven specimens, June 16, 18, 25, July 2. They are mostly large, and of a dark, even stone gray, the lines nearly lost. My Eastern specimens, and others from Corvallis, Oregon, and Wellington, while variable, are all much lighter, some nearly white, with distinct markings. One of the Kaslo specimens, however, is nearly normal, thus dispelling the idea of a local race. Eggs were obtained from a captive female, but I was unable to find the food plant.

Egg.-Elliptical, strongly flattened, compressed, one end smaller and depressed, both rounded; reticulations uniform, rounded and broad, elongate hexagonal, low rounded bars, the areas between nearly flat, granular shagreened. Pale yellow; size, 0.9 by 0.5 by $0.3 \mathrm{~mm}$.

Stage I.-Head rounded, full, pale brown, slightly darker mottled over the sides, a dark band on the median suture, edged with lighter. Body moderate, not elongate, feet normal; pale brown, a broad darkbrown dorsal band, a similar less distinct ventral one, diluted on the posterior rims of the segments. Feet pale; segments irregularly annulate; tubercles minute, brown; setæ moderate, fine, minutely enlarged at tip.

\section{XYSTROTA HEPATICARIA Guenée,}

No specimens; one from Mr. Cockle's collection, June 1 (Ainsworth).

\section{LEPTOMERIS QUINQUELINEARIA Packard.}

Nineteen specimens, June 15, 18, 23, 24, 25, July 1, 2, 4, 6, 17, 21 (Bear Lake, Mr. Cockle) and one from Mr. Cockle's collection, June 17. The larvæ will be described by me in Life Histories of North American Geometridæ, LXII.

\section{LEPTOMERIS SIDERARIA Guenée.}

Four specimens, June 24, 29 and one from Mr. Cockle's collection. This species was placed by Doctor Hulst in Eois, but, as the females have four spurs on the hind tibiæ, I change the generic reference. 
The eastern inductata Guenée is likewise wrongly placed and should go with this species. Eggs were obtained and the larvæ carried to stage iv, but here they hibernated and could not be induced to develop the last stage. By October 10 they had all died.

Egg.-Elliptical, compressed but rounded, no depression, tapering to the micropylar end, which is small, truncate. Laid on the large blunt end like butterfly eggs. Vertically ribbed, about nine ribs on the broad side, low, rounded, finely waved yet distinct; cross striæ slight, not waved, forming rectangular cells; upper end coarsely rounded reticulate; all minutely granular shagreened. Pale yellow, spotted with pale pink; size, 1 by 0.6 by $0.5 \mathrm{~mm}$.

Stage I.-Head round, slightly bilobed, pale brown, ocelli black. Body very slender, elongate, the segments numerously finely annulate. Pale whitish with subdorsal and subventral parallel, rather broad darkbrown stripes, the subdorsal pair rather remote anteriorly, diluted by the luteous cervical shield, approximate behind but separated by a linear pale streak to the anal plate; subventral band more smoky and pale. Foot of joint 13 brown lined; tubercles small; setæ short with enlarged ends.

Stage II.-Head bilobed, free, pale whitish with a band of spots over the lobes, eyes and antennæ black marked; width, $0.5 \mathrm{~mm}$. Body long, slender, curled in twisted S-shape, finely annulate. Dorsum broadly brown with a central geminate dorsal line; subventer pale green broadly on the fold below a broad pale olivaceous band. Feet pale; tubercles small, round, pale with black hair dots and shortblack truncate setæ.

Stage III.-Head round, whitish, dotted with brown over the vertex except in a central streak on the lobe; width, $0.7 \mathrm{~mm}$. Body slender, finely annulate, brown dorsally, a whitish dorsal line darker edged, a darker edge above the broad, greenish-white stigmatal stripe. Subventer very dark; a ventral white stripe. Cervical shield pale like the head; abdominal feet whitish without, dark brown before.

Stage IV.-Head rounded, slightly bilobed, white below, yellowish on the vertex, thickly dotted with pale brown except a streak on each lobe; width, $1 \mathrm{~mm}$. Body slender, uniform, cylindrical, finely annulate. Pale brown dorsally, subventral fold pale yellow, venter dark brown, the colors shaded. A narrow addorsal blackish dotted line, a series of dark-brown spots, two to each segment, joined by an obscure dark subdorsal shade, a lighter medioventral line. Abdominal feet light without; tubercles small; setæ short, thick, brown; no shields.

The larvæ ate alder and Polygonum.

EOIS ROTUNDOPENNATA Packard.

Seven specimens, June 9, 16, 25, 29, and three from Mr. Cockle s collection, June 17 and 20, 1902. The specimens agree well with Packard's description of two males from Brunswıck, Maine, except 
that I can detect no " pale ocherous, slightly scalloped line at the base of the fringe" and there are small blackish spots at the ends of the veins not mentioned by Packard. The lines vary much in distinctness. I shall describe the larvæ in Life Histories of North American Geometridæ, LXV.

\section{EUCROSTIS VIRIDIPENNATA Hulst.}

No specimens; one in Mr. Cockle's collection. I have described the larva in Life Histories of North American Geometridæ, XXVIII. ${ }^{a}$

SYNCHLORA RUBRIFRONTARIA Packard.

One specimen, July 4, and one from Mr. Cockle's collection, June 26, 1902, essentially like eastern specimens.

APLODES RUBRIFRONTARIA Packard, var. DARWINIATA, 'new variety.

Sixteen specimens, June 9, 16, 20, 23, 25, 30, July 4, 19, August 3, $5,6,7$. The dates indicate two broods. I am doubtful about the standing of this form. It looks different from eastern mbrifrontaria, being larger, but I can not find any differential character that seems constant. Doctor Packard says: "I am unable to detect any differences between the Pacific coast and Atlantic coast individuals in the markings or colors." Yet his description of the larva states it to be green, whereas the Kaslo ones are brown. I incline to the opinion that there are two species; certainly there seems enough difference to warrant racial distinction. Besides the larger size may be mentioned a tendency to have red points in the fringe at the ends of the veins and the occasional presence of red-brown discal dots on all wings. The white dorsal spots on the abdomen are narrowly circled with red, not overspread with that color even in the females. Mr. Cockle had the species named Anaplodes pistacearia Packard in his collection, but this is erroneous, as the male has a hair pencil on the hind tibiæ and dorsal abdominal spots. I shall describe the larvæ in Life Histories of North American Geometridæ, LVII.

Type.-Cat. No. 7104, U. S. National Museum.

ORTHOFIDONIA SEMICLARATA Walker.

Six specimens, May 29, 31, June 4, 11 (Fletcher's ranch). A few eggs were obtained from a captive female, but the little larva failed to feed.

Egg.-Elliptical, distinctly flattened above and below, the flattenings not quite reaching the edge which is rounded; ends rounded, not truncate, depression of antemicropylar end not marked. Perfectly 
smooth (87 diameters), the cell areas just indicated by obscure flattenings. Pale yellow, later more or less spotted with red which brings out the obsolete reticulations better; size 0.6 by 0.4 by $0.3 \mathrm{~mm}$.

Stage I.-Head bilobed, clypeus high, shining honey yellow, eye black, mouth brown. Body slender, rather short but looping rapidly, all honey yellow, unmarked. No shields; tubercles invisible; setæ short, capitate, dusky.

\section{ORTHOFIDONIA EXORNATA Walker.}

Five specimens, May (Mr. Cockle), May 29, June 5,

DEILINIA BEHRENSARIA Hulst.

Eleven specimens, May 31, June 2, 13, 16, 19, July 14, 19, August 4. Apparently double brooded. The specimens vary in color from gray (var. cervinicolor) to ocherous gray, but none are as light as Californian specimens. I have described the larva in Life Histories of North American Geometridæ, L. ${ }^{a}$

\section{DEILINIA QUADRARIA Grote.}

Three specimens, June 6,15 , and one from Mr. Cockle's collection June 22, 1901. I have described the larva from Colorado in Life Histories of North American Geometridæ, XXXIV. ${ }^{b}$ Eggs were obtained from a captive female and the larvæ reared on Ceanothus to the fourth stage, when they were lost.

\section{DEILINIA PULVERARIA Hulst.}

Forty-six specimens, May (Mr. Cockle), May 29, 30, 31, June 1, 2, $3,4,5,9,16$. The species is rather constant. I have described the larva in Life Histories of North American Geometridæ, XLIX. ${ }^{c}$

\section{DEILINIA FUMOSA Hulst.}

Two specimens, one Sandon (G. C. Robbins), the other bred from a larva beaten from Ceanothis by Mr. Cockle, emerged August 23.

Larva.-Head rounded bilobed, clypeus high; green, dotted with white, tubercles and setæ dark; width, $2.4 \mathrm{~mm}$. Body normal, moderate, smooth; green, finely white streaked and dotted. Addorsal line white, faint, subdorsal more distinct, both faint on the concolorous cervical shield, absent on the anal plate; lateral line about like the subdorsal; substigmatal yellow, narrow, diffusing a yellow shade on the green about it, especially at the stigmata which are orange, brown rimmed. Tubercles round, small, neatly black; feet green; triangular - plate of anal feet slightly black dotted. 
DEILINIA RECTIFASCIA Hulst.

Forty-eight specimens, May (Mr. Cockle), May 30, June 3, 4, 5, 6, 9, 10, 13, 16, 20, 21, 22, 23, July 4, 8, 15 17, 25, 26, and one from Mr. Cockle's collection labeled Deilinia faminaria Guenée. The color varies from nearly white to pale ocherous, with reddish shades at the outer halves of both wings. I have described the life history in Life Histories of North American Geometridæ, LII, ${ }^{a}$ where I have made some remarks on the generic position of the species.

\section{DEILINIA LITARIA Hulst.}

Thirty-three specimens, April 15 (Mr. Cockle), May 30, June 1, 9, 25, and one specimen from Mr. Cockle's collection, June 3, 1901, labelled Deilinia falcataria Packard. Very variable, especially in the females, which are markedly smaller than the males. One female specimen, nearly without markings, seems to be almost the exact counterpart of Packard's fermiginosaria, described from a single female from California. I think the name litaria will ultimately fall before an older one, perhaps fermginosaria Packard, or faminaria Guenée, or falcataria Packard; but as there are many species of Deilinia attached to Ceanothus in the West, all variable and closely allied (six are here listed from Kaslo), and as the falcataria group is not before me in large series, I will let the name stand for the present. I have described the larva in Life Histories of North American Geometridæ, LI. ${ }^{b}$

\section{DEILINIA ERYTHREMARIA Guenée, var. PACIFICARIA Packard.}

Fourteen specimens, May 30, June 3, 9, 13, 16, 20, July 4, 21 (Bear Lake, Mr. Cockle), August 7. This is the western form of erythremaria, slightly larger and more distinctly marked. I have described the larvæ in Life Histories of North American Geometridæ, XLVHI.

\section{DEILINIA VARIOLARIA Guenée.}

Two specimens, June 24, July 25, and one from Mr. Cockle's collection, June 17. They are not in good condition, but appear referable to this species. Mr. G. W. Taylor has sent me a specimen agreeing with the Kaslo ones as Cymatophora subalbaria Hulst from New Jersey. However, in this case I prefer Mr. Cockle's determination, as I think I see a fovea on the hind wings below, which makes the species a Deilinia.

Proc. N. M. vol, xxvii-03-62 
SCIAGRAPHIA GRANITATA Guenée.

Fifteen specimens, May 29, June 2, 3, 5, 10, 16, 24, 25, 29, July 10 (Ainsworth), 29 (Bear Lake Mountain), and three from Mr. Cockle's collection. Two of these bear labels "punctolinearia Packard" and "nubiculata Packard," but I think these determinations erroneous. The larva will be described by me in Life Histories of North American Geometridæ, LVI. It feeds on spruce and mimics the needles of the second year's growth in color.

\section{SCIAGRAPHIA DENTICULATA Grote.}

No specimens; one in Mr. Cockle's collection agrees rather nearly, though not exactly, with one from Montana so named for me by the late Doctor Hulst.

\section{SCIAGRAPHIA NEPTATA Guenée.}

Twenty specimens; May 31, June 3, 16, 23, July 7, 18 (bred), 24, 31, August 3, 4, 18, September 8 (Glacier, dead in a lamp). Rather variable in color, the lines more or less sinuous, the yellow shading in the transverse posterior line sometimes obsolete. It is very nearly allied to irrorata Packard. Both feed on the poplar. I shall describe the larva of neptata in Life Histories of North American Geometridæ, LXIII; irrorata was described in No. XXX."

\section{SCIAGRAPHIA CONTINUATA Walker.}

No specimens; one in Mr. Cockle's collection is small and worn, but apparently referable here.

MACARIA MINORATA Packard, var. INCOLORATA, new variety.

Five specimens; May 29, June 11, 25, 26, and one from Mr. Cockle's collection August 5, 1902. The form differs from the eastern minorata in its slightly larger size, nearly obsolete emargination of the outer margin of fore wing, and obscure gray coloration, all the contrasts of the black and reddish marks being lost and the head and collar being gray with only a trace of the orange marking. It will not unlikely be found to represent a distinct species, but I prefer to list it for the present as a western race of minorata.

Type.-Cat. No. 7879, U. S. National Museum.

\section{CYMATOPHORA LATIFERRUGATA Walker.}

No specimens; one in Mr. Cockle's collection so named. In Bulletin No. 52, United States National Museum, Doctor Hulst makes this species synonymous with pustularia Hübner, although in 1895 he "felt 
uncertain about this." a The synonymy is certainly erroneous, for Hübner's excellent figure is not in the least like latiferrugata. I have no direct information at present about Walker's type, but Packard's type of brumearia is before me, and I assume them to be the same, since Walker's description does not disagree. The Kaslo specimen, though somewhat worn, agrees well with Packard's type.

CYMATOPHORA INQUINARIA Hulst.

Twenty-three specimens; July 8, 12, 18, 19, 23, 24, 25, 26 (Payne Mine), 30, 31, August 3, 5, 6, 7, and two from Mr. Cockle's collection. Distinctly variable, yet characteristic. It looks very much like Sympherta julia Hulst. The larva was not obtained. My other specimens are from Placer County, Cal. (Koebele), and the Mariposa Big Tree Grove, California (Dyar).

\section{CYMATOPHORA BIACTATA Walker.}

One specimen, Sandon (G. C. Robbins) and one from Mr. Cockle's collection.

\section{CYMATOPHORA MATILDA, new species.}

Twenty specimens, June 3, 9, 10, 13, 17, 20, 21, 24, July 14, 27, and one from Mr. Cockle's collection labeled Eois anticaria Walker; but the species has vein 5 of the hind wings absent and is therefore not even an Eois.

Male antennæ with short, clavate, hairy pectinations decreasing to the tip, of female simple. Yellowish white, front with a narrow line of dark scales at its summit, vertex and collar faintly yellowish, wings with minute dark atoms forming a line on the base of the costal edge. Two faint, dark, nearly straight lines on fore wing, one on hind wing, the outer line placed unusually near the margin on both wings, being at the outer fourth. Inner line of fore wing may be absent and both are always faint. In some a faint discal dot on hind wing. Below unmarked or with discal dot on both wings. Fore wing square at the apex but not falcate, hind wing rounded. Expanse, 24-27 mm.

Type.-Cat. No. 7880, U. S. National Museum.

I have a specimen from Colorado. Concerning Eois anticaria Walker (=subalbaria Packard), Packard states that the antennæ are pectinated, which shows that it is not an Eois, but probably referable to Xystrota. It is certainly not my species even if it should prove to be a Cymatophora, for mine does not agree in markings with Packard's figure and description.

SYMPHERTA TRIPUNCTARIA Packard.

One specimen, July 23 (Frye Creek) and one from Mr. Cockle's collection without label. 
ENEMERA JUTURNARIA Guenée.

Thirty-two specimens, June (Mr. Cockle), June 23, 30, July 4, 13, 14, 15, 17, 18, 19, 23, 25, 26 (Payne Mine), August 4, 11, Sandon (G. C. Robbins). Many more could have been obtained as the moth is easily started up in the daytime. The species is single brooded with hibernation in the egg state. I have described the egg ${ }^{a}$ and larva. ${ }^{b}$

\section{CARIPETA ÆQUALIARIA Grote.}

No specimens; one in Mr. Cockle's collection, July 7, 1901. The specimen differs from æqualiaria that I have from Victoria; Easton, Washington; Portland, Oregon; California and Williams, Arizona, in being darker, the pinkish tint obscured by brown, the marginal pale dashes absent, and the marginal orange rays on the hind wings reduced. Beneath it does not differ from normal specimens. This probably represents a distinct local race, but without more material I can not feel certain.

\section{CARIPETA DIVISATA Walker.}

One specimen, July 11.(Ainsworth, Currie and Caudell). It differs in some respects from eastern specimens, but without a series I cannot judge whether these differences are constant enough to define a local race.

\section{PHENGOMMAT $Æ A$ EDWARDSIATA Hulst.}

No specimens; one from Mr. Cockle's collection, August 23, 1902.

\section{ENYPIA PERANGULATA Hulst.}

Sixty-one specimens, July 29, 30, August 1, 2, 6, 7, 8, 10 (on snow, Kokanee Mountain), 13 (Sandon, Mr. Currie), 16, 17, 18, 20 (Nelson), 20 (West Robson), 21 (Revelstoke), 22 (Revelstoke), and one from Mr. Cockle's collection August 9, 1901, as well as Sandon specimens collected by Mr. G. C. Robbins. Very constant and darker than the Pacific coast form venata Grote, of which it may nevertheless be a local race. It appears smaller and narrower winged than venata, and the latter is remarkably variable. I hold it, therefore, provisionally as a distinct species. The range is down the Rocky Mountains. I have speeimens from Taos Mountain, New Mexico, and Silverton, Colorado. Eggs from females taken at Nelson, where the species was commonest hatched but were not raised, as I was leaving the district and could not attend to them.

Egg.-Elliptical, thick and regular, sides strongly concavely flattened, ends rounded and nearly alike, scarcely any truncation or 
depression; smooth. Pale yellowish greenish, scarcely any color, shining, turning bark brown; size, 1.3 by 1 by $0.7 \mathrm{~mm}$. Laid singly, adherent, all covered with gray scales from the moth, so that they appear like woolly balls.

Stage I.-Head large, round, slightly bilobed, pale red brown. Body moderate, rather short, slate gray, cervical shield and spots at tubercles i and ii pale luteous, subventral fold, feet and anal plates pale.

\section{PHILEDIA PUNCTOMACULARIA Hulst.}

No specimens, but Mr. Cockle has taken it. The species flies late in summer, and none had emerged by August 18, when I left Kaslo. I took it later on Vancouver Island. In Bulletin No. 52, U. S. National Museum (p. 320), I note the spruce defoliating geometrid, reported by Dr. A. D. Hopkins, as being this species. This is probably an error, since Mr. Theodore Bryant informs me that he has bred punctomacularia from larvæ on the common brake (Pteris).

\section{NEPYTIA UMBROSARIA Packard.}

Two specimens, one from Mr. Cockle, one August 20 (Nelson) and one from Mr. Cockle's collection, August 12, 1901. Very rare, perhaps a little out of its range. I have it from Portland and Mount Angel, Oregon, and Santa Cruz Mountains, California.

\section{ALCIS SULPHURARIA Packard.}

Thirty-one specimens, June 23, 26, 30, July 3, 4, 19, 23, 24, 25, 27, $29,30,31$, August 11, 12 . Very variable, the markings tending to reduction or nearly complete obsolescence (var. unicoloraria Hulst). Eggs were obtained from captive females, but they hibernated without hatching.

Egg.-Elliptical, well flattened, but without flat areas, rounded; ends much alike, without marked truncation or depression. Ribbed, about 10 on the flat side in the center, diminishing to both ends irregularly; waved and cut nearly through at each obsolete cell, the resulting elevations crested each by two pores not in line with the rib; crests of pores white. Obsolete cross striæ show as low, rounded bars, principally on the flanks of the ribs. Surface minutely granular shagreened. Micropylar end without ribs centrally. Orange ochraceous; later all red; size, 1 by 0.6 by $0.4 \mathrm{~mm}$.

PARAPHIA SUBATOMARIA Wood.

No specimens; one from Mr. Cockle's collection, July 17, 1901. 


\section{SPODOLEPIS SUBSTRIARIA Hulst.}

Four specimens, May 13 (Mr. Cockle), June 2, 3, the later ones much worn; also one from Mr. Cockle's collection, April 23.

\section{GABRIOLA DYARI Taylor.}

No specimens; one in Mr. Cockle's collection.

SELIDOSEMA HUMARIUM Guenée, var. EMASCULATUM, new variety.

Five specimens, June 30, July 16, 18, and one from Mr. Cockle's collection, much darker than the others. In markings this form agrees closely with eastern humarium. It is, however, much slighter in build and the secondary sexual characters of the male are less developed. The hind tibiæ are swollen, but not nearly as strongly as in humarium. There is a groove on the inner side, but I do not detect a hair pencil in it.

Type._Cat. No. 7881, U. S. National Museum.

\section{CLEORA PAMPINARIA Guenée.}

Five specimens, June 7, 10, 13, and one from Mr. Cockle's collection, June 1, 1901. I have the species from Wellington, and Seattle, Washington.

\section{CLEORA UMBROSARIA Hübner.}

No specimens; one from Mr. Cockle's collection. The specimen agrees with two in the National Museum bearing Dr. Packard's original labels "Boarmia indicataria, comp. Walker's type" and "Boarmia umbrosaria Hbn., B. gnophosaria Gn.," the specimens originally coming from the Meske and Riley collections. They are males and show a hair pencil on the hind tibiæ, so I transfer umbrosaria to Cleora, following Hulst's separation of Cleora and Selidosema.

MELANOLOPHIA CANADARIA Guenée, var. SUBGENERICATA, new variety.

Five specimens, May 29, 30, June 3, 4, and one from Mr. Cockle's collection. The specimens are generally larger and darker than the Eastern form and differ decidedly in the reduction of the secondary sexual characters. I shall describe the larvæ in Life Histories of North American Geometridæ, LX. They feed on spruce, mimicking the young needles in color. Ir the male moths the lateral abdominal tufts are very small, in some hardly perceptible, and the hind tibiæ are less swollen than in Eastern specimens and are more slender, though bearing a distinct hair pencil. I have the form also from Mount Angel, Oregon (F. Epper), Push, Oregon (H. Ahlers), Seattle, 
Washington (T. Kincaid), and Rossland (W. R. Johnson). The Rossland specimen was named "Alcis sp." by Doctor Hulst, apparently on the supposition that the male had a fovea on the fore wings below; but I am unable to see it.

Type. Cat. No. 7106, U. S. National Museum.

ÆTHALOPTERA INTEXTATA Walker.

Twenty-five specimens, April 18 (Mr. Cockle), 25 (Mr. Cockle), May 31, June 2, 9, and two from Mr. Cockle's collection, May 15.

ECTROPIS CREPUSCULARIA Schiffermüller.

Three specimens, June 1. In collecting, this species was confounded with Melanolophia canadaria, so that the usual efforts to obtain eggs were not made in this case, much to my present regret.

LYCIA COGNATARIA Guenée.

One specimen, August 1. I have described the larva in Life Histories of North American Geometridæ, XL. ${ }^{a}$

\section{ERANNIS VANCOUVERENSIS Hulst.}

No specimens; one from Mr. Cockle's collection, October 14. I have it also from Pullman, Washington (C. V. Piper). Hulst calls this form $E$. defoliaria variety vancouverensis; but I see no more reason for regarding it as a variety of the European defoliaria than of the Eastern tiliaria Harris. The fact is that all the American forms of Erannis are but slightly divergent geographical expressions of the European one and will doubtless be finally so listed. Yet, pending the examination of a larger series of all the forms, I will temporarily regard the Northwestern form as specific.

DYSCIA ORCIFERATA Walker.

No specimens; one in Mr. Cockle's collection, July 6, 1901.

SICYA MACULARIA Harris.

Five specimens, July 14, 25, 31, September 9 (Field).

THERINA LUGUBROSA Hulst.

No specimens; on from Mr. Cockle's collection labeled T. somniaria Hulst. However, it agrees well with Hulst's type of Tugubrosa before me from Rossland. From somniaria the form differs in being much more densely strewn with the gray strigæ, which are confluent and dominate the coloration. T. somniaria has been shown to feed on the oak in the larval state, a plant which does not grow at Kaslo. Therefore, I judge that lugubrosa is really a distinct species. 
METROCAMPA PRÆGRANDARIA Guenée.

Twenty-four specimens, June 28, July 2, 4, 7, 14, 15, 19, 21, 25. The peculiar larvæ with an additional pair of feet on the fifth adominal segment and with subventral fringe were fed on birch, the bark of which they closely mimicked. I have described them in Life Histories of North American Geometridæ, XLIII."

\section{ENNOMOS MAGNARIUS Guenée.}

One specimen, sent me by Mr. Cockle and one from his collection.

PLAGODIS APPROXIMARIA Dyar.

No specimens; one in Mr. Cockle's collection, June 3 (Ainsworth). I have the species also from Rossland and Portland, Oregon.

\section{HYPERITIS TRIANGULIFERATA Packard.}

Thirty-two specimens, May 29, 30, 31, June 2, 3, 4, 5, 7, 8 (Ainsworth), 10, 12, 13, 16, 18, 23, July 4, 24 . Some have the brown mark above anal angle (var. notataria Hulst), others lack it entirely and there are all intergrades in the obsolescence of the marking. The basal costal spot is likewise evanescent. The form notataria is not specifically distinct as listed by Hulst. The larvæ occurred on currant. I shall describe them in Life Histories of North American Geometridæ, LIV. Prof. G. H. French has previously described them. ${ }^{b}$

HYPERITIS AMICARIA Herrich-Schaeffer.

Seven specimens, May 31, June 1, 8 (Ainsworth), 9, 11, 25. The larve were raised on wild cherry. I shall describe them in Life Histories of North American Geometridæ, LV, and give some notes on the form of imago occurring at Kaslo.

ANIA LIMBARIA Haworth.

One specimen sent me by Mr. Cockle and one from his collection, July 24.

GONODONTIS DUARIA Guenée.

No specimens; one from Mr. Cockle's collection.

EUCHLÆNA PECTINARIA Schiffermüller.

One specimen, June 25, and one from Mr. Cockle's collection labeled E. sirenaria Strecker. It does, indeed, agree with Strecker's description of sirenaria, but the form is that usually identified as pectinaria, and I do not see that Strecker has done more than make a synonym. 
My specimen was a female and deposited eggs which hatched and were carried to stage $\mathrm{v}$ when they were all lost by a fungoid disease. 'I have described the larva in Life Histories of North American Geometridæ, XXXII. ${ }^{a}$

\section{EUCHLANA ASTYLUSARIA Walker.}

Nine specimens, June 9, 19, 24, 25, 27, July 2. They agree with Coloradan examples. As compared with eastern specimens they are more yellowish, the strigæ fewer and less defined, the dark shade beyond the transverse posterior line lighter and either partially or wholly wanting. This may be Hulst's manubriata, which I do not know. I will describe the larvæ in Life Histories of North American Geometridæ, LIX.

\section{EUTRAPELA ALCIPHERARIA Walker.}

One specimen, May 30. The specimen was a female, but the eggs were infertile. I have the larvæ from Mr. Theodore Bryant, Wellington, who points out to me that the two broods of the species are different, the spring brood being large and heavily marked, the summer brood small and lightly marked. I have described the larvæ in Life Histories of North American Geometridæ, III. ${ }^{b}$

\section{METANEMA TEXTRINARIA Grote and Robinson.}

Two specimens, June 8 (Ainsworth), 11, and one from Mr. Cockle's collection.

AZELINA ANCETARIA Hübner, var. OCCIDENTALIS Hulst.

Twenty-six specimens, July 15, 26, 29, 30, August 4, 5, 6, 7, 12, 21 (Revelstoke). This is, I think, Hulst's Marmarea occidentalis. Only two of my specimens are males. In describing occidentalis, Doctor Hulst calls it a "Darwinian species"- that is to say, in this case, a geographical race - and he erects the new genus for it on the slight difference in the male antennæ. In the Kaslo specimens this is certainly extremely slight. Neither is it greater in specimens from California and Arizona before me. The Kaslo specimens are all decidedly larger than eastern ancetaria, agreeing with Doctor Hulst's specific diagnosis of occidentalis. So while there is a possibility that I have not the true occidentalis, I do not think this is the case. I am of the opinion that when a character is admittedly not of specific value it can not be used to define a genus, even if it be "structural." Therefore I place Hulst's genus Marmarea as a synonym of Azelina and his species occidentalis as a variety of ancetaria. The life history was started, but I failed to complete it. 
Egg. - Eiliptical, smoothly and evenly rounded, no perceptible flattening nor truncation; surface smooth, shagreened. Shining sordid olivaceous, under a lens minutely black speckled; size, 0.9 by 0.7 by $0.65 \mathrm{~mm}$.

Stage I.-Head rounded, bilobed, pale brown, erect, sutures depressed. Body moderately elongate, normal, whitish, marked with irregular green rings from the alimentary canal before eating; a very faint, narrow, brown subdorsal line. Segments annulate; cervical shield small, black; tubercles black, a slight blackening around the hair dots only; setæ stiff, minutely flared at the tip.

Stage II. - Face below and epistoma broadly bluish white, edged above with a straight black shade; vertex yellowish, with brown black spots in alternating oblique rows; width, $0.75 \mathrm{~mm}$. Body moderately slender, normal, dark gray, many fine irregular brown lines on a greenish gray ground; venter darker than dorsum, which is irregularly diluted greenish. Feet concolorous; tubercles round, black; setæ pointed, dark.

The larvæ began to hibernate at this point and finally died.

\section{SABULODES CATENULATA Grote.}

One specimen, June 25, and one from Mr. Cockle's collection, August 1,1902 .

\section{BREPHOS INFANS Möschler.}

No specimens; one from Mr. Cockle's collection, June 24 (Ainsworth).

\section{Family NOLID A.}

\section{CELAMA MINNA Butler.}

One specimen, May 31. It differs somewhat from minna from California and Vancouver Island, but without a series it is not possible to define the racial characters, if such exist. In the specimen the subcostal mark on the transverse-anterior line is much reduced, while the transverse-posterior line is an obviously geminate row of dots, filled by a little darker shade. Larvæ of this, as I suppose, occurred on Ceanothus. They are not yet bred.

Larva.-Head bilobed, pale yellow, densely checkered with brown, leaving the paraclypeal pieces yellow; epistoma white. Body flattened, no feet on joint 7; warts normal, formed with tubercles i+ii and iv $+v$. Cervical shield small, bisected. Body checkered yellow and brown, joints 5,7 , and 11 broadly brown dorsally; a narrow brown dorsal line, straight; subdorsal, lateral, and subventral waved broad brown bands, broken in the incisures, dark and subconfluent on the dark segments, avoiding the warts. Warts ocherous, ringed with 
brown. Hair bristly, black tipped, some long ones laterally. Feet pale. Wart iv $+v$ is lighter than the others. The dorsal band is widened on joints 3-4 and 12 and shows distinctly in dark specimens. Very variable in the intensity of coloring.

Cocoon boat-shaped, made of bits of bark on a stem in the wellknown manner.

\section{Family PSYCHIDA.}

\section{PSYCHE FRAGMENTELLA Henry Edwards.}

No specimens. A single immature larva was found in its characteristic case but it failed to mature.

\section{Family COCHLIDIID A.}

TORTRICIDIA TESTACEA Packard.

Three specimens, June 13. They agree with specimens from Manitoba and Colorado, and are probably referable to the form crypta Dyar. A single larva was found on birch, but it was parasitized, and died before the characteristic markings had appeared. This is the westernmost record (except in the extreme Southwest) for any Cochlidian in North America. The rarity of the species prevented as complete observations as are desirable.

\section{Family COSSID E.}

\section{COSSUS POPULI Walker.}

No specimens; one in Mr. Cockle's collection, July 27, 1902, is a male in good condition, expanding $60 \mathrm{~mm}$. It resembles undosus Lintner, but the collar is grayer and the lines on the wings are less pronounced, more broken and strigose.

\section{Family SESIID A.}

\section{ALBUNA PYRAMIDALIS Walker.}

Ten specimens, June 11, 18, 23, July 11 (Ainsworth), 21 (Bear Lake Mountain), 28 (Bear Lake Mountain), taken at flowers. Five are normal pyramidalis, three of the variety mbescens, and two of the variety coloradensis. The extremes suggest different species, and it is not surprising that they were described as such.

SESIA TIPULIFORMIS Linnæus.

No specimens; one in Mr. Cockle's collection, June 27. 


\section{Family PYRALID A. \\ SYMPHYSA ERIPALIS Grote.}

One specimen, August 20 (Nelson), in very poor condition, seems referable here.

\section{DESMIA FUNERALIS Hübner.}

No specimens; one from Mr. Cockle's collection.

\section{EVERGESTIS FUNALIS Grote.}

No specimens; one from Mr. Cockle's collection. I took the species later on Vancouver Island.

NOMOPHILA NOCTUELLA Schiffermüller.

Twenty-four specimens, May 31, June 1, 2, 3, 4, 5, 7, July 19, 23, 24, 25, August 1, 14 (Revelstoke, Mr. Currie), 21 (Revelstoke).

\section{LOXOSTEGE COMMIXTALIS Walker.}

Four specimens, June 4, and one from Mr. Cockle's collection.

\section{PHLYCT $Æ N I A$ FERRUGALIS Hübner.}

One much-worn specimen, July 28 (Bear Lake), may be of this species, and another equally bad from Mr. Cockle's collection. My specimen is of the usual size, but Mr. Cockle's is larger, like the form from the Pacific coast (profundalis Packard).

\section{PHLYCT ÆNIA TERREALIS Treitschke.}

No specimens; one in Mr. Cockle's collection, June 22, 1902.

\section{PHLYCT $Æ$ NIA TERTIALIS Guenée.}

No specimens; one in Mr. Cockle's collection, June 7.

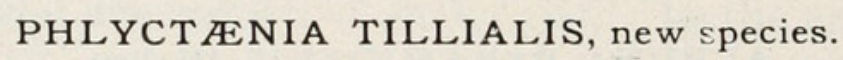

Two specimens, August 7, September 9 (Field), and one from Mr. Cockle's collection, August 23, 1902. Light, whitish, straw yellow, irregularly shaded with reddish brown, especially toward costa and outer margin. Reniform and orbicular large, nearly solidly brownblack filled, fused to a concolorous costal stripe that reaches two-thirds to the apex. Transverse-anterior line nearly obsolete, linear, bent out on median vein; transverse-posterior punctiform, moderately arcuate, not distinct. A row of small, terminal black dots. Fringe brown, whitish checkered without. Hind wings subpellucid whitish, faintly testaceous tinged, a small fuscous, obscure discal spot and faint shadow of a dusky outer line, indefinite. Expanse, $24 \mathrm{~mm}$.

Type.-Cat. No. 7829, U. S. National Museum. 
PHLYCT ANIA ITYSALIS Walker.

No specimens; one from Mr. Cockle's collection, July 1.

PYRAUSTA FUMOFERALIS Hulst.

Twelve specimens, June 1, 10, 11, 16, 23, 24, 29, July 18, 26 (Payne Mine), and one from Mr. Cockle's collection.

PYRAUSTA UNIFASCIALIS Packard.

One specimen, July 29 (Bear Lake Mountain), and one from Mr. Cockle's collection, June 11.

\section{PYRAUSTA BOREALIS Packard.}

Seven specimens, May 29, 31, June 2, and one from Mr. Cockle's collection, June 28, 1902. The specimens are rather small and much shaded with black, the hind wings especially being nearly solidly black from the inner line to the base. The eight specimens are alike, but another from Mr. Cockle's collection, without label, is of the usual larger and paler form.

PYRAUSTA OCHOSALIS Dyar.

No specimens; one from Mr. Cockle's collection, June 20, 1902.

PYRAUSTA NICALIS Grote.

No specimens; one in Mr. Cockle's collection.

\section{PYRAUSTA INCONCINNALIS Lederer.}

No specimens; one from Mr. Cockle's collection, which differs a little from my Colorado and Arizona examples in having a trace of a line on the hind wings.

\section{PYRAUSTA FUNEBRIS Stromeyer.}

Four specimens, June 11, and one from Mr. Cockle's collection, July 3, 1902 .

\section{PYRAUSTA ÆGLEALIS Walker.}

No specimens; one from Mr. Cockle's collection, July 31, 1901.

\section{CORNIFRONS SIMALIS Grote.}

No specimens; one from Mr. Cockle's collection.

$$
\text { NOCTUELIS THALIALIS Walker. }
$$

Ten specimens, June 11, 23, 25, July 11 (Ainsworth), and one from Mr. Cockle's collection. 
SCOPARIA CENTURIELLA Schiffermuller.

Twenty-six specimens, June 18, 20, 22, 23, 25, July 2, 13, 14, 16, 19, 23, 29 (Bear Lake Mountain), August 6, 7, 8, 11, 13 (Sandon, Mr. Currie), 17, Sandon (G. C. Robbins), and one from Mr. Cockle's collection.

\section{SCOPARIA NOMINATELLA Hulst.}

Twelve specimens, July 19, 24, August 1, 3, 6, 7, 17, September 1 (Shawnigan Lake, Vancouver Island), and two from Mr. Cockle's collection, August 17, 1902, and August 17, 1903.

SCOPARIA FERNALDALIS Dyar.

One hundred and eighty-seven specimens, June 24, July 7, 15, 25, 30, August 4, 5, 12, 30 (Shawnigan Lake) and two from Mr. Cockle's collection, August 30, 1902.

SCOPARIA RECTILINEA Zeller.

One hundred and seventy-six specimens, July 8, 15, 24, 27, August $5,6,11,12,13,17,29$ (Shawnigan Lake) and one from Mr. Cockle's collection, July 20, 1901.

\section{SCOPARIA TRICOLORALIS Dyar.}

One specimen, July 10 (Ainsworth) and two from Mr. Cockle's collection, July 7 and August 3, 1902.

\section{PYRALIS ELECTALIS Hulst.}

No specimens; one from Mr. Cockle's collection, July 2.

PYRALIS FARINALIS Linnæus.

Ten specimens, June 16, 17, 24, 27, July 23, 30, August 7, 13.

\section{CRAMBUS HAMELLUS Thunberg.}

Sixty-three specimens, August 16, 17, 21 (Nakusp), 21 (Revelstoke), September 2 (Wellington). The ground color of the wings varies from the usual dark brown to gray or yellowish gray, showing that the Californian cypridalis Hulst, which differs only in the ground color, is not specifically distinct from hamellus.

\section{CRAMBUS PASCUELLUS Linnæus.}

Seven specimens, June 13, 18, July 2, 7 (Lardo), 15, 17, and one from Mr. Cockle's collection, August 3, 1902.

\section{CRAMBUS UNISTRIATELLUS Packard.}

One specimen, July 17, and one from Mr. Cockle's collection, July 20,1901 . 
CRAMBUS HORTUELLUS Hübner.

Thirty-seven specimens, June 11, 15, 16, 23. The specimens vary in color from light (toparius Zeller) to dark (vachellellus Kearfott), the majority being intermediate.

CRAMBUS MYELLUS Hübner.

Eighteen specimens, July 16, 18, 24, 25, 30, August 3, 4, 5, 6, 7, 13, 19, and one from Mr. Cockle's collection, July 21, 1902.

\section{CRAMBUS VULGIVAGELLUS Clemens.}

Three specimens, August 22 (Revelstoke), 28 (Victoria), and one from Mr. Cockle's collection, September 1, 1902.

CRAMBUS PLUMBIFIMBRIELLUS, new species.

Sixteen specimens, June 14, 16, 19, 20, 29, July 3, 7 (Lardo), 23 (Frye Creek), August 4, 7, and one from Mr. Cockle's collection, July 3,1902 . Sordid whitish, palpi sprinkled with gray; fore wings whitish, tinged with ocherous, especially along terminal space and outer half of costa; all the interspaces filled with scattered gray-brown scales. These scales are grouped to occasionally indicate a median line, bent outward across cell, but faint and usually wanting. Outer line near the margin, roundly bent below apex, then straight and parallel to margin; a row of seven terminal black dots; fringe shining lead color. Hind wings sordid white, a faint dark line close to the margin, a little more remote at the anal angle. Expanse, $20 \mathrm{~mm}$.

Type.-Cat. No. 7827, U. S. National Museum.

\section{CRAMBUS OREGONICUS Grote.}

Nine specimens, July 15, 21 (Bear Lake Mountain), 28 (Bear Lake Mountain), August 3, 21 (Revelstoke), September 2 (Wellington).

CRAMBUS MURELLUS, new species.

No specimens; one from Mr. Cockle's collection, without date, and two from Pullman, Washington (C. V. Piper). Fore wing light gray, dusted with darker; an illy defined pale carneous shade over lower half of wing, spreading from the median fold, fading before the tornus. Scarcely any lines; subterminal faint, finely linear, dark, minutely dentate and slightly excurved opposite the cell, not very near the margin. Terminal black dots very small; fringe not at all metallic. Hind wings dark gray, the fringe pale, almost white. Expanse, 22 to $24 \mathrm{~mm}$.

Type.-Cat. No. 7826, U. S. National Museum. 


\section{CRAMBUS BONIFATELLUS Hulst.}

Thirty-four specimens, June 1, 8 (Ainsworth), 13, 15, July 15, 19, 21 (Bear Lake), 24, 25, 31, August 7, 21 (Revelstoke), 22 (Revelstoke), and two from Mr. Cockle's collection, May 26, 1901, June 11. This obscurely marked species varies considerably, the white speck used as a differential character by Doctor Fernald being inconstant. There appears in many specimens a dark outer line, curved outward beyond the cell.

\section{CRAMBUS TRISECTUS Walker.}

Five specimens, August 21 (Revelstoke), September 2 (Wellington), and one from Mr. Cockle's collection, August 17, 1901.

MYELOIS CORNIELLA Ragonot.

Sixteen specimens, July 15, 24, 31, August 1, 5, 7, 17, 21 (Revelstoke), 22 (Revelstoke), and two from Mr. Cockle's collection, June 24 and July 8,1901 . The black scales of fore wing form indefinitely a line from the costal inception of the outer line to the inner margin at middle of wing. This is shown distinctly in Ragonot's figure, but it is faint in my specimens and often not determinate.

DIORYCTRIA ABIETELLA Schiffermüller.

One specimen, June 20, and one from Mr. Cockle's collection, July 2,1901 .

\section{DASYPYGA ALTERNOSQUAMELLA Ragonot.}

One specimen, August 6, of this very pretty and distinctly marked species. I have another from Williams, Arizona (Schwarz and Barber), and two from Seattle, Washington (O. B. Johnson).

AMBESA WALSINGHAMI Ragonot.

No specimens; one from Mr. Cockle's collection, August 4. This species is not represented in the National Museum collection.

NEPHOPTERYX SUBTINCTELLA Ragonot.

Two specimens, June 16, 25, and two from Mr. Cockle's collection, June 24, 1901, and June 7, 1903.

\section{NEPHOPTERYX OVALIS Packard.}

No specimen; one from Mr. Cockle's collection, June 28, 1902, is rather larger and lighter colored, but essentially similar to eastern specimens. 
MEROPTERA PRAVELLA Grote.

One specimen, June 13, and two from Mr. Cockle's collection, May 27, 1902, and July 7, 1902.

SALEBRIA LAEVIGATELLA Hulst.

No specimens; one from Mr. Cockle's collection, May 29, 1901.

LAODAMIA FUSCA Haworth.

Three specimens, July 29 (Bear Lake Mountain), August 4, 31 (Shawnigan Lake), and one from Mr. Cockle's collection, July 7, 1902.

ETIELLA ZINCKENELLA Treitschke.

No specimens; one from Mr. Cockle's collection, July 3, 1902.

ZOPHODIA PACKARDELLA Ragonot.

One specimen, April 30 (Mr. Cockle), and two from Mr. Cockle's collection, April 28, 1901, and May 20, 1902.

EUZOPHERA OCHRIFRONTELLA Zeller.

Two specimens, July 23, 30.

ECCOPISA SERRATILINEELLA Ragonot.

Four specimens, August 17, September 4 (Shawnigan Lake), and one from Mr. Cockle's collection, June 24, 1902.

HULSTIA UNDULATELLA Clemens.

Twenty-eight specimens, April 27 (Mr. Cockle), June 27, 28, July 1, 3, 4, 10 (Ainsworth), 15, and one from Mr. Cockle's collection, July 8, 1902.

EPHESTIA AMARELLA, new species.

Three specimens, June 13, 23, 24. Fore wings with 9 veins, hind wings with 7 ; tongue long; ocelli absent, palpi erect, hind wings with veins 3 and 4 connate. By these characters it falls between Eurythmia and Unadilla, according to Hulst's tables, but is really an Ephestia.

Light gray; a carneous reddish shade along inner third of wing, most distinct on submedian fold in median space. Inner line obsolete, but indicated by a broad, light blackish outer edge, which forms a straight, slightly oblique band. Discal spot of two superimposed dots. Outer line obsolete, indicated by its rather narrow, blackish inner shade, inwaved opposite cell and on submedian fold. Hind wings whitish, fuscous along costa. Expanse, $18 \mathrm{~mm}$.

Type.-Cat. No. 7828, U. S. National Museum,

Proc. N. M, vol. xxvii-03-63 
HOMCEOSOMA MUCIDELLUM Ragonot.

One specimen, June 24, and one from Mr. Cockle's collection, June 20,1902 .

\section{EPHESTIODES GILVESCENTELLA Ragonot.}

Four specimens, June 18, July 1, August 13, and one from Mr. Cockle's collection, June 27.

EPHESTIODES BENJAMINELLA, new species.

Five specimens, June 22, July 19, 24, 25, August 3, two from Mr. Cockle's collection, July 19, 1901, August 17, and five from Pullman, Washington (C. V. Piper), July 11, 12, 1898, and August 2, 1899. Dark fuscous with a red tint. Lines more or less obscured, pale, edged with blackish toward median space; discal dots black, indistinct. Hind wings fuscous. Anal tuft of male sordid ocherous. Expanse, $13-14 \mathrm{~mm}$.

The form differs from gilvescentella Ragonot and nigrella Hulst by the fuscous hind wings. It seems nearest allied to erythrella Ragonot, which I have not seen, but is not so red, that being described as "dark vinous red, dusted with black on costa and veins.'

Type-Cat. No. 7830, U. S. National Museum.

Respectfully dedicated to Dr. Marcus Benjamin, the efficient editor of these Proceedings.

\section{Family PTEROPHORID A.}

\section{PLATYPTILIA COSMODACTYLA Hübner.}

Three specimens, July 11, 12, 19 and one from Mr. Cockle's collection, June 21, 1902. The larvæ were found in the red bracts of the high bush honeysuckle (Lonicera involucrata), eating holes in the young fruit through the bracts and destroying the fruit. A larva in the penultimate stage had the following characters. I have described the mature larva from a Coloradan specimen. ${ }^{a}$

Larva.-Head bilobed, shining black. Cervical shield quadrate, black; thoracic feet and anal plate black; tubercles brown, angularly plated, i and ii with a pale hair and very short black one separate, i dorsad to ii; tubercle iii also with multiple hairs; two secondary hairs, very short, black, below tubercle i; tubercle iiia present; iv $+\mathrm{v}$ with a secondary hair closely adjoining; vi single. Skin with sparse, dark, secondary granules. Dorsum broadly whitish with dorsal reddish line; sides dull reddish, stigmatal region whitish. The mature larva has numerous secondary hairs. 
PLATYPTILIA TESSERADACTYLA Linnæus.

Two specimens, July 29 (Bear Lake Mountain), August 11 (Kokanee Mountain).

\section{PLATYPTILIA CARDUIDACTYLA Riley.}

Five specimens, June 5, 23, July 21 (Bear Lake), August 5, and one from Mr. Cockle's collection, June 24.

OXYPTILUS NINGORIS Walsingham.

Seven specimens, June 25, 27, 29, August 3. The young larvæ were found webbing the heads and deforming the leaves of a wooly herbaceous plant with milky juice, Hieracium albiflomum. The larvæ were very small but made a great showing as the whole head of the plant is webbed and distorted, the leaves crumpled and the flower shoot does not grow up as it normally would.

Larva.-Head small, bilobed, pale honey yellow, mouth pointed. Body robust, tapering a little at the ends, feet normal, slender, dilated at the ends as usual in the Pterophoridæ. Primary hairs simple, coarse, white, i and ii closely approximated, the tubercles black; iii single, iv and $\mathrm{v}$ closely approximated, vi single, the tubercles brownish ringed. Numerous small secondary hairs all over, white, short, broadly clavate tipped. Olivaceous green, the food dark; skin densely covered with minute black, flat granules; spiracles black ringed. Later there is a deep brown spot on tubercle $\mathrm{i}+\mathrm{ii}$.

Pupa.-Attached by the anal extremity, free; pale yellow, the tubercles like those of the larva, the dorsal ones colored red. The young larva is w:thout the eapitate secondary hairs.

\section{OXYPTILUS TENUIDACTYLUS Fitch.}

Two specimens, June 23 (bred). The larvæ occured on the thimbleberry (Rubus nutkanus) with the normal structure and coloration. I have described them from New York specimens on blackberry. ${ }^{a}$

\section{PTEROPHORUS ANGUSTUS Walsingham.}

Thirty-three specimens, June 9, 10, 11, 13, 20, 21, 23, 24, 25, 30, July 11 (Ainsworth), 24, 25, and one from Mr. Cockle's collection June 10, 1902. The moths were easily started up from low grass and weeds, but especially from the plant Anaphatis margaratacea, which I suppose is their food plant. Larvæ were found commonly in the flower heads of this plant, but unfortunately were not bred. The following is a description of them:

Larva.-Head shining brown-black, bilobed, the clypeus reaching vertex, rounded at top; mouth pointed. Body robust, flattened, 
tapered behind, feet normal, small. Densely covered with brownblack, flat granules, forming a double patch dorsally, bisected by a pale dorsal line; ground color whitish, forming a subdorsal band; segmental incisures shagreened. Tubercles i and ii separate, i dorsally placed, with secondary hairs; iv and $\mathrm{v}$ separate. Later the larva is whitish, with the flat black granules; dorsal, subdorsal, and stigmatal purplish bands, the dorsal band geminately segmentarily bimaculate in blackish.

\section{PTEROPHORUS HELIANTHI Walsingham.}

No specimens; one from Mr. Cockle's collection, August 10 (South Fork Creek), may be referable to this species, although it lacks the subapical brown dash shown in Lord Walsingham's figure. The two discal dots are present, and the brown powdering around the fissure.

\section{PTEROPHORUS BRUCEI Fernald.}

Two specimens, August 12, September 4 (Shawnigan Lake, Vancouver Island), in poor condition, but seeming to agree with specimens from Colorado so named for me by Dr. C. H. Fernald.

STENOPTILIA COLORADENSIS Fernald.

One specimen, June 25, agrees well with Doctor Fernald's type before me, except that it is smaller.

\section{Family ORNEODIDA.}

\section{ORNEODES HEXADACTYLA Linnæus.}

One specimen, July 13 (bred), and one from Mr. Cockle's collection, April 24. The moth emerged in a jar containing leaf miners on snowberry, but I am not certain that I have correctly observed the larva.

\section{Family TORTRICID E.}

\section{OLETHREUTES CAPREANA Hübner.}

One specimen, July 9, and one from Mr. Cockle's collection. Mr. W. D. Kearfott, in kindly going over my Tortricid material from Kaslo, named this form frigidana Packard. His determination may be perfectly correct, but, if so, frigidana can not be a distinct species from the European capreana.

\section{OLETHREUTES CAMPESTRANA Zeller.}

Sixty-three specimens, June 7, 10, 11, 13, 16, 18, 19, 20, 22, 23, 24, 25, 26, 27, 30, July 2, 3, 4, 8, 10 (Ainsworth), 11 (Ainsworth), 19, 25, August 3,4. The larvæ of this common little species occurred on the thimbleberry (Rubus nutkanus). 
Larva.-Head rounded, squarish, held obliquely, smooth and even in front, clypeus highly triangular; deep black, slightly shining, mouth a little paler, basal joint of antennæ pale. Cervical shield large, dull black, vinous tinted. Body slender, very active, uniformly dark vinous brown throughout; anal plate black; tubercles small, slightly raised, appearing paler than the body by reflection of light, really concolorous. Setæ moderate, brownish, longer on the anal end, $\mathrm{iv}+\mathrm{v}$; on thorax ia $+\mathrm{ib}$ and iia $+\mathrm{iib}$.

\section{OLETHREUTES CORUSCANA Clemens.}

Thirty-seven specimens, June 11, 13, 16, 17, 18, 19, 20, 22, 23, 24, 25, 29, 30, July 1, 2, 4, 10 (Ainsworth), 13, 15, and one from $\mathrm{Mr}$. Cockle's collection, June 18, 1902. The specimens are larger than eastern comscana, the hind wings paler. Some examples closely approach constellatana Zeller.

\section{OLETHREUTES DUPLEX Walsingham.}

Five specimens, June 10, 12, 16, and one from Mr. Cockle's collection, June 27, 1901. The green larvæ were found on aspen, but spun before a description had been prepared.

\section{EUCOSMA CIRCULANA Hübner.}

No specimens; one from Mr. Cockle's collection. The specimen is large, like those I have from Manitou, Colorado, and Huachuca Mountains, Arizona, and the transverse obscure silvery bands are straight. The costal fold is closely applied and difficult to see. I can not positively observe it in the Kalso specimen, though it is fairly obvious in some of the others.

\section{EUCOSMA CASTANEANA Walsingham.}

Nineteen specimens, June 26, 27, July 10, and one from Mr. Cockle's collection, June 24 . The moths were common, flying about the gooseberry bushes on which their larvæ fed.

\section{EUCOSMA JUNCTICILIANA Walsingham.}

No specimens; one from Mr. Cockle's collection resembles eastern specimens so nearly that I do not venture to separate it.

\section{EUCOSMA AGRICOLANA Walsingham.}

Two specimens, June 11, 17, and one from Mr. Cockle's collection.

\section{EUCOSMA ATOMOSANA Walsingham.}

No specimens; one from Mr. Cockle's collection, considerably worn, seems probably referable to this species on comparison with Walsingham's figure. 


\section{EUCOSMA TRANSMISSANA Walker.}

One specimen, July 28 (Bear Lake Mountain) and three from Mr. Cockle's collection, May 13 , June 11, are apparently very near to transmissana Walker, if not really that species. They may retain the identification pending the receipt of more complete collections.

EUCOSMA DORSISIGNATANA Clemens.

Two specimens, sent by Mr. Cockle, taken probably sometime in August.

EUCOSMA PULSATILlana Dyar.

Three specimens, July 24, 25, 29 and one from Mr. Cockle's collection, July 31. The larvæ were found webbing and killing the leaves of clematis.

EUCOSMA SIMILANA Hübner.

Nospecimens; two from Mr. Cockle's collection, October 1, 1902.

EUCOSMA CRENANA Hübner.

Forty-four specimens, March 26 (Mr. Cockle), June 1, 29, July 1, $2,5,6,8,24,25,31$, August 4, 5, 6, 11, 12, 13, 17, and six from Mr. Cockle's collection, March 29, April 4, June 6, September 21, October 20. This seems inseparable from the European species. Mr. Kearfott has recently described it as Proteoptery $x$ columbia ${ }^{a}$ with two varieties, but I do not think the new name necessary. It is extremely variable, but my European series of six specimens match nicely the forms columbia Kearfott and albidorsana Kearfott. It should certainly not be placed in Proteopteryx, which has no costal fold in the male. ${ }^{b}$ Meyrick ${ }^{c}$ gives the larva on willow. A number of my specimens were bred from this plant, but so mixed with other species that I can not give a description of the larva with certainty.

\section{THIODIA APACHEANA Walsingham.}

Eight specimens, June 23, 24, and one from Mr. Cockle's collection, June 11. They agree well with one from Los Angeles, California (Koebele), identified by Lord Walsingham in 1887. They are a little larger and the markings seem brighter, which is probably due to their being fresher. In going over this species with Mr. Kearfott we concluded that it was Eucosma albangulana Walsingham; but in this we were hasty, as the male has no costal fold. It resembles the figure of that species, however.

\footnotetext{
${ }^{a}$ Can. Ent., XXXVI, 1904, p. 112.

$b$ As this is in press I see that Professor Fernald corrects Lord Walsingham's diagnosis of Proteopteryx to include the costal fold. Can. Ent., XXXVI, 1904, p. 120.

${ }^{c}$ Handb. Brit. Lep., 1895, p. 493.
} 
THIODIA PSEUDOTSUGANA Kearfott.

Twenty specimens, June 24, July 9, August 4, 10 (Kokanee Mountain), 17, and three from Mr. Cockle's collection, April 10, 1902, August 10 (Kitchener Glacier). Several of the specimens were found torpid on snow. The larvæ were beaten from a spruce tree at Powder Creek.

Larva.-Head bilobed, elongate, reddish luteous, sutures and jaws dark brown, eye black, antennæ white at base, black at tip. Cervical shield large, black, shading paler before, rather broadly bisected. Later head red brown, epistoma and bases of antennæ white. Cervical shield green, except the black posterior rim. Body green without marks.

\section{THIODIA ARCTOSTAPHYLANA Kearfott.}

Seven specimens, all raised from larvæ on bearberry (Arctostaphylos uva-ursi). They emerged late in August. The larvæ are sordid whitishwith red brown heads and spin up the ends of the shoots of the plant, eating out the terminal bud. I found the same larvæ two years previously high on the foothills back of Golden, Colorado, where the bearberry grows. These moths also emerged in August.

Larva.-Head rounded, apex in joint 2, shining brown, clypeus high. Cervical shield rather large, shining luteous, transparent, shading to black behind. Anal plate brown-black; some small shields on joint 13 anteriorly, a single dorsal and a subdorsal. Body robust, tapering at the ends, not very active; translucent greenish yellow, food opaquely green; tubercles small but distinct, blackish luteous, $\mathrm{ia}+\mathrm{ib}$, iia $+\mathrm{ib}, \mathrm{iv}_{\mathrm{v}} \mathrm{v}$, i dorsad to ii. Feet normal, short, the thoracic ones black.

THIODIA ELONGANA Walsingham, var. TRANSVERSA Walsingham.

Ten specimens, June 8 (Ainsworth), and one from Mr. Cockle's collection, June 30, 1902. Three are elongana, seven of the form transversa. I can not regard these as distinct species. They were flying commonly in a dried-out swamp near Loon Lake above Ainsworth, but alighting among dead brush were very difficult to capture.

THIODIA ARTEMISIANA Walsingham, var. INFIMBRIANA, new variety.

Three specimens, June 23, August 9 (South Fork Creek), and two from Mr. Cockle's collection, August 4 and August 17, 1902. The specimens are a little smaller than the typical form, the dark bands on the wing rather less oblique and the fringe light gray like the bands, not discolorously bright brown.

Type. Cat. No. 7659, U. S. National Museum. 
EPINOTIA BIANGULANA Walsingham.

One specimen, October 13 (Mr. Cockle) and one from Mr. Cockle's coilection, September 30. These nearly agree with Lord Walsingham's figure and may remain under the name, at least temporarily.

EPINOTIA LINDANA Fernald.

Five specimens, August 8, 11, and two from Mr. Cockle's collection, September 2, September 6, 1902. Mr. Cockle's specimens have the dark costal part of the fore wings red brown, while mine are dark brown. His specimens are probably discolored. The larvæ occurred on dogwood (Cornus), spinning up the leaves and killing them.

Larva.-Head retracted in joint 2, shining brown, blotched with black, epistoma and bases of antennæ pale. Cervical shield large, black. Abdomen slender, colorless whitish, tubercles slightly shining.

\section{EPINOTIA MEDIOPLAGATA Walsingham.}

Seven specimens, June 20, 21, 25, July 2, 21 (Bear Lake Mountain), and one from Mr. Cockle's collection, July 3, 1902. Mr. Kearfott and myself, after comparing carefully Lord Walsingham's figure and description, have concluded that we have correctly identified this form.

ANCYLIS MEDIOFASCIANA Clemens.

No specimens; two from Mr. Cockle's collection, June 11 and 27. EUDEMIS VACCINIANA Packard.

One specimen, July 23.

\section{ANCYLIS BIARCUANA Stephens.}

One specimen, the label lost, and one from Mr. Cockle's collection, June 11.

ANCYLIS PACIFICANA Clemens.

Four specimens, May 29, 31, June 3, and one from Mr. Cockle's collection, May 9, 1902.

\section{ENARMONIA NIGRICANA Stephens.}

No specimens; three from Mr. Cockle's collection, May 28, June 10, 1901, of which I have retained one for the National Museum. The species was omitted from Bulletin No. 52 by Doctor Fernald, but is well known to occur in Canada. ${ }^{a}$

$a$ Bull. U. S. Dept. Agr., Div. Ent., No. 33, new series. 1902, p. 96. 
ENARMONIA COCKLEANA Kearfott.

Twenty-five specimens, June 15, 16, 17, July 1, 2, 4, 8, 19, 23, 25, 26, and one from Mr. Cockle's collection, July 3, 1902. Extremely near the European cruciana Linnæus and in all probability not specifically distinct therefrom. The European larva feeds on wiliow. Many of my specimens were bred from this plant. The following is a description of the larvæ, but there is a chance that it is not correct, as the cultures from the willow buds yielded a mixture of species and the description may have been taken from a Eucosma crenana.

Larva.-Head bilobed, pale translucent brown, irregularly smoky shaded over the lobes, apex retracted, clypeus high, eye and a dash behind black, mouth brown. Body moderately slender, not very active, translucent pale greenish yellow, the food showing opaquely green, not filling the body. Cervical shield shining translucent pale luteous, a little smoky blotched about the edges. Tubercles concolorous, minute, a little shining; setæ pale. Feet normal, pale, no plates; several short stiff spines at the end of the anal flap. Tubercles ia+ib, iia + iib, iv $+\mathrm{v}$.

ENARMONIA GALLÆSALICANA Riley.

One specimen, June 25, determined by Mr. W. D. Kearfott.

HEMIMENE PLUMBANA Scopoli.

Fourteen specimens, June 4, July 28 (Bear Lake Mountain), 29 (Bear Lake Mountain).

HEMIMENE ALPINANA Treitschke.

Four specimens, June 12, 20, 25, and one from Mr. Cockle's collection June 24.

ACLERIS VARIANA Fernald.

Nine specimens, June 11, August 3, September 9 (Field), 10 (Banff, Alberta), and seven from Mr. Cockle's collection, July 8, 1902, October $16,19,20,1902$.

\section{ACLERIS SCABRANA Curtis.}

One specimen, June 1, which Mr. Kearfott named trisignana Robinson; but does not correspond with it, as I have these species separated.

ACLERIS FERRUGINIGUTTANA Fernald.

One specimen, August 30 (Shawnigan Lake, Vancouver Island), and one from Mr. Cockle's collection, April 15, 1902.

\section{ACLERIS EFFRACTANA Froelich.}

Two specimens, July 6, August 4. Much darker than the European species and possibly specifically distinct therefrom. One specimen was bred from a jar of mixed pupæ. 
ACLERIS HASTIANA Linnæus, var. SIGNATANA Heyden.

Four specimens, August 6,8, and five from Mr. Cockle's collection, showing much variation. The two specimens which I refer to the variety signatana were bred from larvæ webbing the heads of Azalea. The head was luteous, body greenish, grayish dorsally but transparent; male glands yellowish. One variety of the moth was small with a yellow stripe. I have one captured specimen of it and one from Mr. Cockle's collection, October 10, 1902. Another variety had a white costal shade, the specimen being from Mr. Cockle's collection, April 20.

ACLERIS SCHALLERIANA Linnæus.

One specimen, July 29, and four from Mr. Cockle's collection, June 6,11 , September 18 .

\section{ACLERIS BRITTANIA Kearfott.}

Sixteen specimens, July 4, 5, 8, 21, 24, August 3, 6, 31 (Shawnigan Lake), September 5 (Shawnigan Lake), and one from Mr. Cockle's collection, August 3,1901. The larvæ were bred on thimbleberry and rose. On the former plant they often bit off the leaves partly, living in the dead and dried portion.

Larva.-Head squarish, full in front, shining brown black, diluted about the mouth. Cervical shield luteous, blackish blotched at the borders. Body moderate, shining transparent greenish, the male glands faintly whitish. Tubercles concolorous, obscure; setæ*small. Thoracic feet black.

\section{ARCHIPS ROSACEANA Harris.}

Thirteen specimens, June 25, July 19, 21, 25, 31, August 6, 7, 12, 13, 26 (Victoria), September 5 (Victoria), and one from Mr. Cockle's collection, July 1, 1901. A specimen was bred from a larva on aspen.

\section{ARCHIPS VIRESCANA Clemens.}

Eighteen specimens, June 16, July 2, 7, 8, 15, 18, 19, 23, 25, August 1, 3, 4, 5, 11, 13, 14 (Revelstoke, Mr. Currie), and one from Mr. Cockle's collection, July 20, 1901.

\section{ARCHIPS ARGYROSPILA Walker.}

Five specimens, July 19, 25, August 12, 15 (in train near Field, Mr. (urrie).

\section{ARCHIPS PERSICANA Fitch.}

Seventeen specimens, June 15, 16, 23, 25, July 2, 15, 21, 23, 24, 25, August 5, 6, 11, and one from Mr. Cockle's collection July 3, 1902. A larva was found on Ceanothus and produced this species. 
Larva.-Head green, opaquely luteous over the lobes, antennæ white at base, black at tip, epistoma white, ocelli black, a short black band on side of head behind. Body translucent green, a faint yellowish line along tubercles i and ii. Cervical shield green, faintly luteous tinged. Thoracic feet blackish; tubercles moderate, whitish, raised, conspicuous with black hair dots; anal plate luteous; tubercles iv $+v$. Dorsal vessel dark green; segments coarsely annulate.

PLATYNOTA SENTANA Clemens.

Thirteen specimens, June 16, 17, 23, 28, July 3, 4, 11, 15, 21, 25, August 5, 6, 7, and two from Mr. Cockle's collection June 21. The larvæ were bred on clematis mixed with Eucosma pulsatillana and also on birch where they had killed the leaves.

Larva.-Head vinous black, diluted with brown streaks, or brown. Cervical shield large, black, shading to luteous on the front border. Body green or purplish, the subdorsal fat body faintly whitish. Tubercles small, white, hair dots black; setæ stiff, pale; thoracic feet largely black; male glands large, dull vinous.

\section{TORTRIX DORSALANA Dyar.}

One specimen, June 30, and one from Mr. Cockle's collection, July 14; 1901 .

TORTRIX ARGENTANA Clemens.

One specimen, June 15, and one from Mr. Cockle's collection.

TORTRIX OSSEANA Scopoli.

No specimens; one from Mr. Cockle's collection, August 10 (Camp Mansfield).

TORTRIX ALBICOMANA Clemens.

Three specimens, June 29, July 4, August 3.

TORTRIX BERGMANNIANA Linnæus.

Four specimens, June 25, 29, July 15,18, and one from Mr. Cockle's collection, July 1.

\section{EULIA MINISTRANA Linnæus.}

One specimen, June 11, and one from Mr. Cockle's collection, June 11.

EULIA GLOVERANA Walsingham.

Four specimens, July 2, 15, 27, August 3; determined by Mr. Kearfott.

PHALONIA DUBITANA Hübner.

No specimens; one from Mr. Cockle's collection, May 30. 


\section{PHALONIA DEUTSCHIANA Zetterstedt.}

No specimens; one from Mr. Cockle's collection, July 12, agreeing essentially with European specimens.

COMMOPHILA FUSCODORSANA Kearfott.

No specimens; one from Mr. Cockle's collection, June 7, formed Mr. Kearfott's type and has been retained in the National Museum.

CARPOSINA CRESCENTELLA Walsingham.

No specimens; one from Mr. Cockle's collection, May 12, 1902, is larger than my Eastern specimens, but not separable specifically therefrom, at least with the present small material.

\section{Family YPONOMEUTID A.}

\section{ALLONONYMA DIANA Hübner, var. BETULIPERDA Dyar.}

One specimen, August 4, bred from a cocoon on alder.

\section{HEMEROPHILA ALPINELLA Busck.}

Four specimens, July 21 (Bear Lake Mountain), and one from Mr. Cockle's collection, July 9, 1901.

\section{CHOREUTIS ONUSTANA Walker.}

Four specimens, June 11, 18, 23, July 21 (Bear-Lake Mountain), and one from Mr. Cockle's collection, July 3, 1902.

\section{CHOREUTIS LEUCOBASIS Fernald.}

Five specimens, May 29, July 12, 13, 14. The larva occurred on Anaphalis margaratacea in a soft web on the top of a leaf, solitary.

Larva.-Head long, elliptical, mouth pointed, lobes full, clypeus high; held flatly; pale luteous, ocelli black, mouth brown. Body cylindrical, tapering at the ends, slender, segments coarsely annulate, feet normal, slender. Pale green; a broad dorsal yellowish, illy defined shade; tubercles small, black, distinct; setæ pale, rather long, iv and $\mathrm{v}$ closely approximated, $\mathrm{v}$ smaller and a little ventrad; no dis̀colorous shields; feet all pale.

Cocoon fusiform, white.

\section{GLYPHIPTERYX IMPIGRITELLA Clemens.}

No specimens; one in Mr. Cockle's collection, May 29. 
CEROSTOMA RADIATELLA Donovan.

No specimens; two in Mr. Cockle's collection, March 27 and April 10,1902 .

TRACHOMA FALCIFERELLA Walsingham.

One specimen, August 7, and two from Mr. Cockle's collection, August 28 and October 20, 1902.

HARPHYPTERYX DENTIFERELLA Walsingham.

One specimen, August 7.

PLUTELLA MACULIPENNIS Curtis.

Fifteen specimens, June 1, 3, 11, 13, 14, 20, July 4, 14, 15, 24, and one from Mr. Cockle's collection, May 28. The larvæ occurred on cabbage and other cruciferous plants.

\section{PLUTELLA POULELLA Busck.}

No specimens; one from Mr. Cockle's collection, July 12, formed Mr. Busck's type and has been retained in the National Museum.

\section{PLUTELLA INTERRUPTA Walsingham.}

No specimens; one in Mr. Cockle's collection, June 24.

\section{ZELLERIA GRACILARIELLA Busck.}

Nine specimens, May 31, July 19, 22, 23, 25, 26, 29. The larvæ occurred on Ribes lacustre, gregariously in a large loose web among the leaves.

Larva. - Slender, head luteous, heavily spotted with black, body with a subdorsal smoky black shade. The cocoon is fusiform, white, in a cloud of delicate white silk with drops of fluid in it.

ZELLERIA RIBESIELLA Busck.

Two specimens, July 22, 25. Bred from the same lot of larvæ that gave the preceding species and it is probably a variety of that.

ARGYRESTHIA PYGM ÆELLA Hübner.

Nine specimens, July 10, 16, 18, 24, August 3, 28 (Victoria).

\section{ARGYRESTHIA GOEDARTELLA Linnæus.}

Forty-three specimens, July 10, 31, August 5, September 3 (Wellington). The Wellington specimens were all collected on alder, which is evidently the food plant of the species. 
Family CECOPHORID A.

DEPRESSARIA ARGILLACEA Walsingham.

Four specimens, June 5, August 6, 21 (Revelstoke), 22 (Revelstoke), and one from Mr. Cockle's collection, April 24.

DEPRESSARIA KLAMATHIANA Walsingham.

Two specimens, August 1, 11, and three from Mr. Cockle's collection, April 1, April 30, 1902, and September 18.

DEPRESSARIA ROSACILIELLA Busck.

One specimen, June 5, and one from Mr. Cockle's collection, May 4, 1901.

\section{DEPRESSARIA ALIENELLA Busck.}

One specimen, August 6.

DEPRESSARIA PALLIDELLA Busck.

One specimen, August 6, and one from Mr. Cockle's collection, August 15, 1901.

BORKHAUSENIA PSEUDOSPRETELLA Stainton.

Four specimens, August 8, 13 (Sandon, Mr. Currie), September 5 (Victoria), and two from Mr. Cockle's collection, June 24, August 12.

BORKHAUSENIA DIMIDIELLA Walsingham.

No specimens; one in Mr. Cockle's collection, June 6.

BORKHAUSENIA BORKHAUSENII Zeller.

Two specimens, June 29, July 25.

BORKHAUSENIA COLORADELLA Walsingham.

No specimens; three in Mr. Cockle's collection, June 24, July 12, and July 1, 1901.

\section{ENDROSIS LACTEELLA Schiffermüller.}

Seven specimens, June 5, 6, 24, 25, July 9, 11 (Ainsworth), and two from Mr. Cockle's collection, June 6 and June 18, 1901. Most of the specimens were taken in the house.

\section{Family GELECHIID $\mathbb{A}$.}

ARISTOTELIA NOTATELLA Busck.

Fifteen specimens, June 22, 23, 29, July 1, 15, August 3, and one from Mr. Cockle's collection, July 3, 1902. 
ARISTOTELIA HARRISONELLA Busck.

Seventeen specimens, June 1, 3, 8, 10, 11, 16, 20, 22, 23, 25, and four from Mr. Cockle's collection, June 6, 11, July 3, 1902.

\section{ARISTOTELIA FUNGIVORELLA Clemens.}

Fifteen specimens, July 25, August 4, 5, 6, 7, 11, 15. The larva occurred on willow, in a soft loose web, eating the parenchyma of the leaf from the upper side.

Larva.--Head rounded, greenish, whitish dotted, and washed with brown above. Body slender, whitish green, opaque, reticular dotted in brown, forming laterally a broad, heavy band; subventral fold lighter. Thoracic feet black, tubercles minute, setæ moderate, iv and $v$ closely approximated, in line.

\section{ARISTOTELIA RUBIDELLA Clemens.}

Nine specimens, June 23, 27, 30, July 15, 23, 25, and one from Mir. Cockle's collection, July 1.

\section{ANACAMPSIS NIVEOPULVELLA Chambers.}

Two specimens, June 24, July 12. One specimen was bred from a leaf roller on willow; the other from a leaf roller and stitcher on aspen. The larva makes a neat roll of the leaf, the ends closed and covered with little stitches on the outside. It eats the inner part.

Larva.-Head slightly bilobed, black, diluted to brown in a blotch on the face; clypeus highly triangular, reaching vertex, shining. Cervical shield shining black, a brown triangular dilution posteriorly and a crooked mark in the center of each half; divided by a pale dorsal line; anterior rim of joint 2 whitish. Body tortriciform, translucent sordid grayish white; tubercles round, black, ia $+\mathrm{ib}$, iia $+\mathrm{ib}$, iv $+v$; anal plate large, brown black; setæ rather long, dusky; thoracic feet black.

\section{GLYPHIDOCERA SEPTENTRIONELLA Busck.}

Seven specimens, July 4, 15, 19, 21, 24.

GELECHIA MANDELLA Busck.

Seven specimens, July 7, August 5, 13 (Sandon, Mr. Currie), 15.

GELECHIA MONELLA Busck.

Eleven specimens, August 5, 6, 7, 12, 15, 16, 17, 18.

GELECHIA ABACTELLA Busck.

Fifty-one specimens, July 19, 24, 30, August 3, 4, 5, 6, 7, 12, 16, 17, 18. Mr. Busck is not certain that all the specimens belong to this species, as he has not critically examined each; but they appear to do so, being of the same size and color. 
GELECHIA CEANOTHIELLA Busck.

Eleven specimens, June 18, 19, 20, 21, 22, July 21, August 4. The larvæ occurred on the Ceanothus sanguineus.

Larva.-Head elongate, oblique, scarcely bilobed, shining vinous black. Cervical shield large, black; thoracic feet also black. All of joints 2 to 4 dark vinous except two bright white incisures, 2-3 and $3-4$, which are folded, white all around. Joints 5 to 13 lined in bluish white and dull vinous, the stripes about equal in width, the pale lines dorsal, subdorsal, lateral, stigmatal. Feet pale; anal plate vinous black. Tubercles small, black; setæ moderate, dusky.

\section{Family ELACHISTID A.}

\section{MOMPHA GRANDISELLA Chambers.}

One specimen, June 21.

\section{MOMPHA DECORELLA Stephens.}

Twenty-eight specimens, July 14, 24, 25, 27, August 15. Bred from large galls in the stems of Epilobium. The gall is fusiform, or nearly spherical, situated in the main stem, usually near the summit, and contains from two to twenty larvæ. The elongate white cocoons are spun within the gall attached to the lids of the apertures of emergence.

\section{SCYTHRIS MAGNATELLA Busck.}

Three specimens, July 20, 22. The larvæ occurred on Epilobizum, solitary, when small, folding over half of the leaf to the midrib in the central part of its length, attached with web. Later they form considerable web among the leaves, and the pupa is formed in a delicate flossy web. Three stages were seen.

Stage IV (?).-Head cordate, black, held flatly. Cervical shield blackish, bisected by a pale line. Body slender, tortriciform; dorsum broadly dull yellow shaded, sharply edged subdorsally, sides vinous tinted, venter sordid green. The dorsal mark is a dorsal and subdorsal band attached together; stigmatal band pale yellow, subventral region vinous tinted; tubercles small, blackish.

Stage V.-Head dull black, a white spot in clypeus, on epistoma and a large one each side of clypeus. Cervical shield large, black, bisected by pale; anterior rim of joint 2 pale. Body washed with yellow dorsally, subdorsal line whitish, lateral region vinous shaded, subventral band white, distinct. Feet, leg shields and rather large tubercles black.

Stage VI.-Head with the whole face white, the sides and vertex black. Cervical shield diluted brown before; anterior rim of joint 2 and bisecting line whitish. Lines all yellow, the subdorsal lost in the dorsal yellow suffusion, the sides vinous black, Tubercles pale with black dots. 


\section{Family TINEID \&.}

GRACILARIA ELONGELLA Linnaeus.

Thirteen specimens, June 11, July 3, 4, 5, 7, 14, 15, 16, and one from Mr. Cockle's collection, May 29. The larvæ occurred on alder. They formed linear mines on the under sides of the leaves ending in a bladder-shaped enlargement. The bladder is contracted, sewn up in a line, the leaf rumpled from midrib to margin. Later the whole leaf is rolled.

Larva.-Head bilobed, narrowed behind, luteous, eye black, jaws brown. Body cylindrical, rather short and robust, whitish translucent, yellowish or greenish from the food, no marks, slightly frosted shagreened. Tubercles invisible, setæ fine, pale, shields conocolorous; tubercles iv and $\mathrm{v}$ closely approximated on the subventral ridge in line, vi present, vii a hair on the leg base.

\section{GRACILARIA STIGMATELLA Fabricius.}

One specimen, July 25 and one from Mr. Cockle's collection, May 9. The larva occurred in a blister mine on the upper side of an aspen leaf at the tip. The linear part of the mine is short, broad, from the midrib outward, the blister large, the upper epidermis only separated, white, adhering again in spots when the green color reappears. The larva emerged, spun up the leaf on the upper side and fed at the ends of the spinning.

\section{LITHOCOLLETIS POPULIELLA Chambers.}

Nine specimens, July 29, August 16. The larvæ occurred in blotch mines on aspen and were very numerous at a point two miles up Kaslo Creek where the aspens were completely discolored by their mines, every leaf containing several of them.

\section{LYONETIA SPECULELLA Clemens.}

One hundred and forty specimens, May 30, 31, June 19, 22, 23, 26, 29 (Bear Lake). The larvæ were enormously abundant on Canothus early in the season, infesting all the leaves to such an extent that they were destroyed and the bushes defoliated. The larve hung from the twigs by long threads so abundantly that the bushes seemed as if covered with spider's webs on which the larvæ hung in rows. They occurred to a less extent on other plants, being found occasionally on wild cherry, apple, birch, and alder. The larva forms a long, tortuous linear mine, starting from a vein and ending suddenly in a blotch. The frass is in a line at first but is ejected from the blotch by holes. The larva has the feet all present. Cocoons hammock-shaped, slung on the back of the slightly curved leaf.

Proc. N. M. vol. xxvii-03-64 
LYONETIA SALICIELLA Busck.

One specimen, July 8, bred from a mine on willow much like that of the preceding species.

\section{LEUCOPTERA PACHYSTIMELLA Busck.}

Five specimens, June 9, 29, July 11, August 4, and one from Mr. Cockle's collection, July 10. They were bred from upper-surface mines in the last year's leaves of the evergreen plant Pachystima myrsinites. The linear mine follows the margin of the leaf, finally forming a blotch which fills the whole leaf. The frass is crowded in a pack at the end. The larva emerges by a hole in the upper surface. It is bright yellow, without feet. The cocoon is spun beneath silken bands on the under side of another leaf.

\section{PHYLLOCNISTIS POPULIELLA Chambers.}

Two specimens, June 12, 16, bred from mines on aspen. The mine is on the back of the leaf, finally covering it entirely, but not kiliing it. The lower epidermis only is separated, the frass in a long brown line; no blotch. The cocoon occupies an enlargement of the mine in a corner of the leaf and is slightly contracted. Rarely the mines occurred on the upper side.

\section{BRACKENRIDGIA ACERIFOLIELLA Fitch.}

Four specimens, June 6, and one from Mr. Cockle's collection, June 6 .

\section{INCURVARIA ÆNESCENS Walsingham.}

One specimen, June 4.

\section{MONOPIS BIFLAVIMACULELLA Clemens.}

Thirteen specimens, July 16, 18, August 9 (South Fork Creek), and two from Mr. Cockle's collection, July 7, 1901, and July 27, 1902.

TINEOLA BISSELLIELLA Hummel.

No specimens; one from Mr. Cockle's collection, May 27, 1902.

TINEA PELLIONELLA Linnæus.

Six specimens, June 17, 30, July 12, 29 (Bear Lake Mountain), August 10 (Kokanee Mountain).

TINEA AUROPULVELLA Chambers.

One specimen, July 23 (Frye Creek). 


\section{$2 \mathrm{BHL}$ Biodiversity Heritage Library}

Dyar, Harrison G. 1904. "The Lepidoptera of the Kootenai District of British Columbia." Proceedings of the United States National Museum 27(1376), 779-938. https://doi.org/10.5479/si.00963801.27-1376.779.

View This Item Online: https://www.biodiversitylibrary.org/item/32794

DOI: https://doi.org/10.5479/si.00963801.27-1376.779

Permalink: https://www.biodiversitylibrary.org/partpdf/3310

\section{Holding Institution}

Smithsonian Libraries

\section{Sponsored by}

Smithsonian

\section{Copyright \& Reuse}

Copyright Status: NOT_IN_COPYRIGHT

This document was created from content at the Biodiversity Heritage Library, the world's largest open access digital library for biodiversity literature and archives. Visit BHL at https://www.biodiversitylibrary.org. 